\title{
政 \\ Review and Prioritization of Technical Issues Related to Burnup Credit for LWR Fuel
}

Prepared by

C. V. Parks, M. D. DeHart, and J. C. Wagner, ORNL

Oak Ridge National Laboratory 


\section{AVAILABILITY NOTICE \\ Availability of Reference Materials Cited in NRC Publications}

NRC publications in the NUREG series, NRC regulations, and Title 10, Energy, of the Code of Federal Regulations, may be purchased from one of the following sources:

1. The Superintendent of Documents

U.S. Government Printing Office

PO. Box 37082

Washington, DC 20402-9328

$<$ http://www.access.gpo.gov/su_docs $>$

202-512-1800

2. The National Technical Information Service

Springfield, VA 22161-0002

$<$ http://www.ntis.gov/ordernow>

703-487-4650

The NUREG series comprises (1) brochures (NUREG/BR-XXXX), (2) proceedings of conferences (NUREG/CP-XXXX), (3) reports resulting from international agreements (NUREG/IA-XXXX), (4) technical and administrative reports and books [(NUREG-XXXX) or (NUREG/CR-XXXX], and (5) compilations of legal decisions and orders of the Commission and Atomic and Safety Licensing Boards and of Office Directors' decisions under Section 2.206 of NRC's regulations (NUREG-XXXX).

A single copy of each NRC draft report is available free, to the extent of supply, upon written request as follows:

Address: Office of the Chief Information Officer

Reproduction and Distribution

Services Section

U.S. Nuclear Regulatory Commission

Washington, DC 20555-0001

E-mail: $\quad<$ DISTRIBUTION@nrc.gov>

Facsimile: 301-415-2289

A portion of $N R C$ regulatory and technical information is available at NRC's World Wide Web site:

\section{<http://www.nrc.gov>}

All NRC documents released to the public are available for inspection or copying for a fee, in paper, microfiche, or, in some cases, diskette, from the Public Document Room (PDR):
NRC Public Document Room

2120 L Street, N.W., Lower Level

Washington, DC 20555-0001

$<$ http://www.nrc.gov/NRC/PDR/pdr1.htm>

1-800-397-4209 or locally 202-634-3273

Microfiche of most NRC documents made publicly available since January 1981 may be found in the Local Public Document Rooms (LPDRs) located in the vicinity of nuclear power plants. The locations of the LPDRs may be obtained from the PDR (see previous paragraph) or through:

\section{$<$ tttp://www.nrc.gov/NRC/NUREGS/}

SR1350/V9/lpdr.html>

Publicly released documents include, to name a few, NUREG-series reports; Federal Register notices; applicant, licensee, and vendor documents and correspondence; NRC correspondence and internal memoranda; bulletins and information notices; inspection and investigation reports; licensee event reports; and Commission papers and their attachments.

Documents available from public and special technical libraries include all open literature items, such as books, journal articles, and transactions, Federal Register notices, Federal and State legislation, and congressional reports. Such documents as theses, dissertations, foreign reports and translations, and non-NRC conference proceedings may be purchased from their sponsoring organization.

Copies of industry codes and standards used in a substantive manner in the NRC regulatory process are maintained at the NRC Library, Two White Flint North, 11545 Rockville Pike, Rockville, MD 20852-2738. These standards are available in the library for reference use by the public. Codes and standards are usually copyrighted and may be purchased from the originating organization or, if they are American National Standards, from-

American National Standards Institute

11 West 42nd Street

New York, NY 10036-8002

$<$ http://www.ansi.org >

212-642-4900

\section{DISCLAIMER}

This report was prepared as an account of work sponsored by an agency of the United States Government. Neither the United States Government nor any agency thereof, nor any of their employees, makes any warranty, expressed or implied, or assumes any legal liability or responsibility for any third party's use, or the results of such use, of any information, apparatus, product, or process disclosed in this report, or represents that its use by such third party would not infringe privately owned rights. 


\section{Review and}

Prioritization of

Technical Issues Related to

Burnup Credit for

LWR Fuel

Manuscript Completed: February 2000

Date Published: February 2000

Prepared by

C. V. Parks, M. D. DeHart, and J. C. Wagner, ORNL

Oak Ridge National Laboratory

Managed by Lockheed Martin Energy Research Corporation

Oak Ridge, TN 37831-6370

C. W. Nilsen, NRC Project Manager

Prepared for

Division of Systems Analysis and Regulatory Effectiveness

Office of Nuclear Regulatory Research

U.S. Nuclear Regulatory Commission

Washington, DC 20555-0001

NRC Job Code W6479

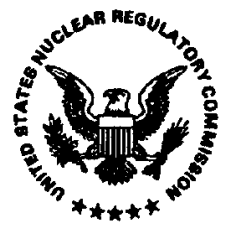





\begin{abstract}
This report has been prepared to review relevant background information and provide technical discussion that will help initiate a PIRT (Phenomena Identification and Ranking Tables) process for use of burnup credit in light-water reactor (LWR) spent fuel storage and transport cask applications. The PIRT process will be used by the NRC Office of Nuclear Regulatory Research to help prioritize and guide a coordinated program of research and as a means to obtain input/feedback from industry and other interested parties. The review and discussion in this report are based on knowledge and experience gained from work performed in the United States and other countries. Current regulatory practice and perceived industry needs are also reviewed as a background for prioritizing technical needs that will facilitate safe practice in the use of burnup credit. Relevant physics and analysis phenomenon are identified, and an assessment of their importance to burnup credit implementation is given. Finally, phenomena that need to be better understood for effective licensing, together with technical issues that require resolution, are presented and discussed in the form of a prioritization ranking and initial draft program plan.
\end{abstract}





\section{CONTENTS}

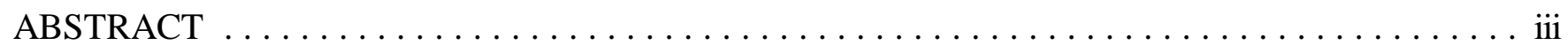

LIST OF FIGURES $\ldots \ldots \ldots \ldots \ldots \ldots \ldots \ldots \ldots \ldots \ldots \ldots \ldots \ldots \ldots \ldots \ldots$ vii

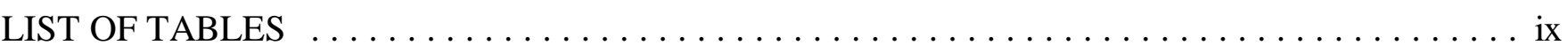

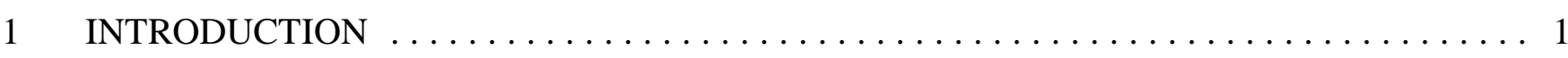

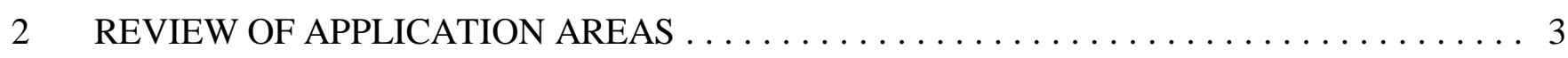

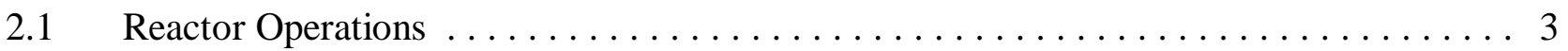

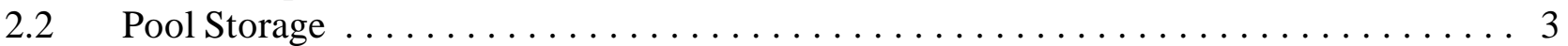

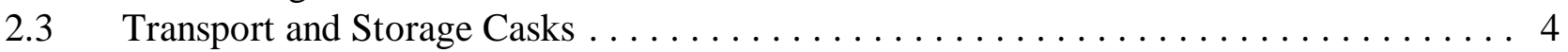

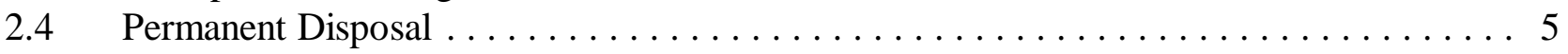

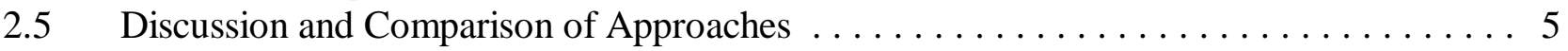

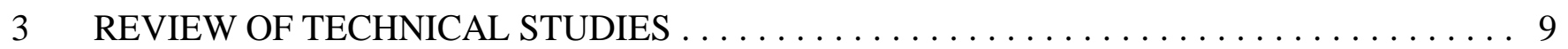

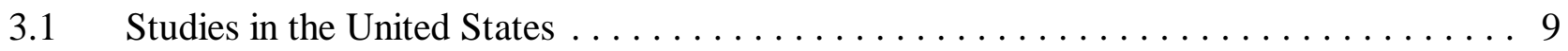

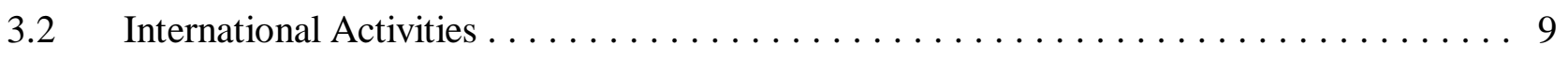

4 PARAMETER AND PHENOMENA IDENTIFICATION $\ldots \ldots \ldots \ldots \ldots \ldots \ldots \ldots \ldots \ldots$

$4.1 \quad$ Nuclides Important to Burnup Credit $\ldots \ldots \ldots \ldots \ldots \ldots \ldots \ldots \ldots \ldots \ldots \ldots \ldots \ldots$

$4.2 \quad$ Parameters for Depletion Analysis $\ldots \ldots \ldots \ldots \ldots \ldots \ldots \ldots \ldots \ldots \ldots \ldots \ldots \ldots \ldots$

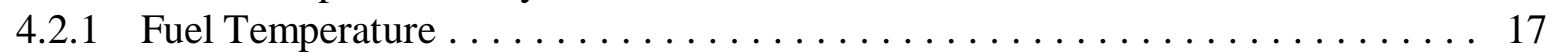

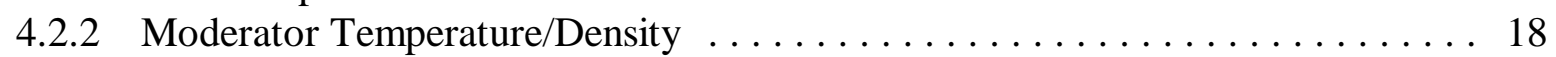

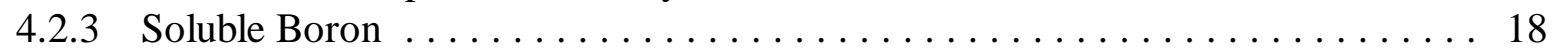

$4.2 .4 \quad$ Specific Power and Operating History $\ldots \ldots \ldots \ldots \ldots \ldots \ldots \ldots \ldots \ldots \ldots \ldots \ldots \ldots \ldots$

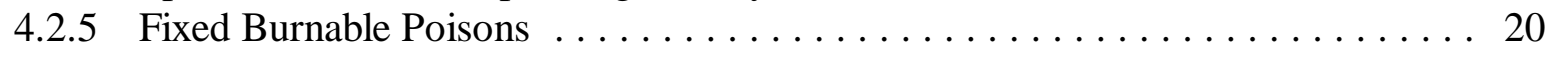

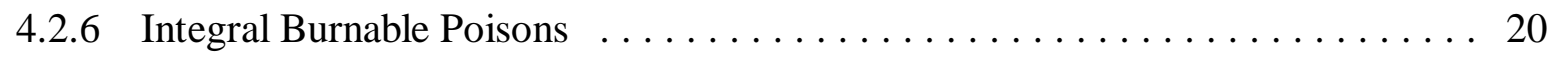

4.2 .7 Summary of Depletion Modeling Parameters $\ldots \ldots \ldots \ldots \ldots \ldots \ldots \ldots 20$

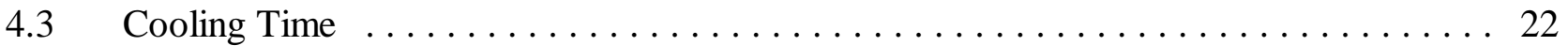

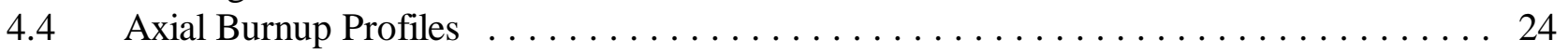

$4.4 .1 \quad$ Phenomena Associated with Axial Effects $\ldots \ldots \ldots \ldots \ldots \ldots \ldots \ldots . \ldots . \ldots . \ldots . \ldots 24$

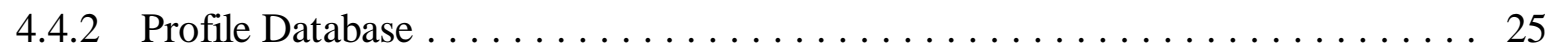

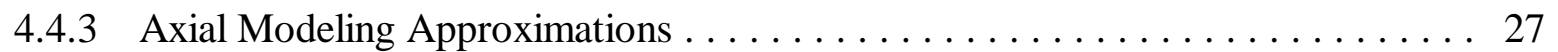

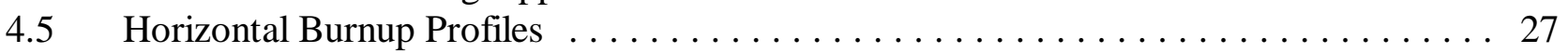

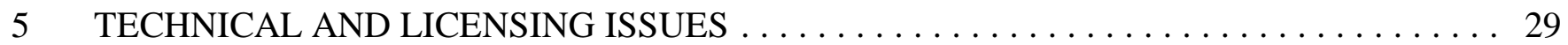

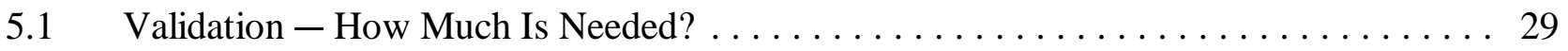

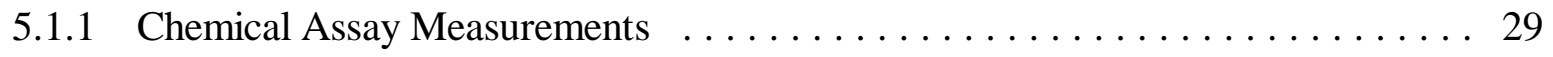

$5.1 .2 \quad$ Critical Experiments with Fresh Fuel $\ldots \ldots \ldots \ldots \ldots \ldots \ldots \ldots \ldots \ldots \ldots \ldots \ldots$

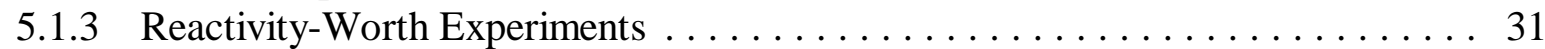

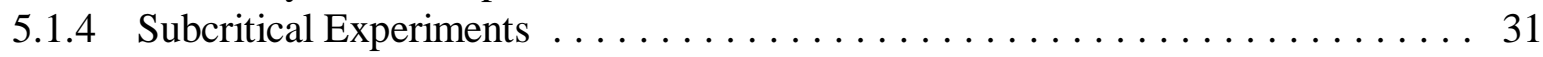

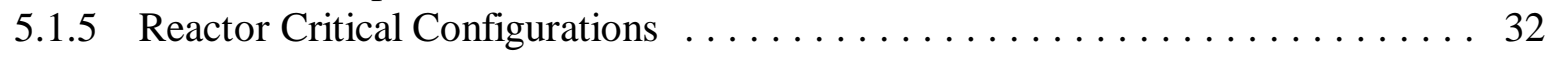




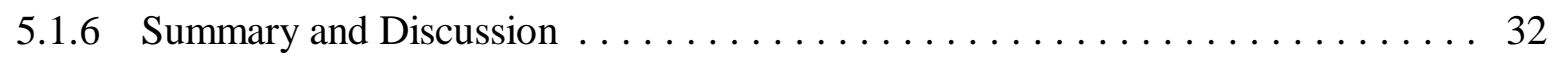

$5.2 \quad$ Modeling Considerations $\ldots \ldots \ldots \ldots \ldots \ldots \ldots \ldots \ldots \ldots \ldots \ldots \ldots$

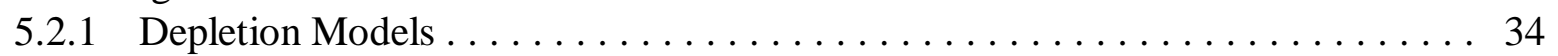

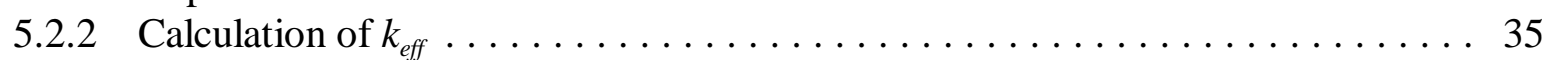

$5.3 \quad$ Confirmation Measurements for Cask Loading $\ldots \ldots \ldots \ldots \ldots \ldots \ldots$

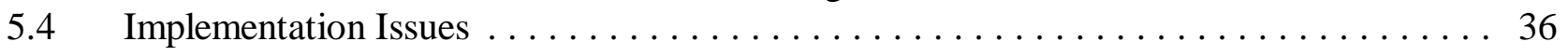

$6 \quad$ PROPOSED RESEARCH AND PRIORITIZATION $\ldots \ldots \ldots \ldots \ldots \ldots \ldots \ldots \ldots \ldots \ldots . \ldots \ldots$

$6.1 \quad$ High-Priority Research $\ldots \ldots \ldots \ldots \ldots \ldots \ldots \ldots \ldots \ldots \ldots \ldots \ldots \ldots$

$6.2 \quad$ Medium-Priority Research $\ldots \ldots \ldots \ldots \ldots \ldots \ldots \ldots \ldots \ldots$

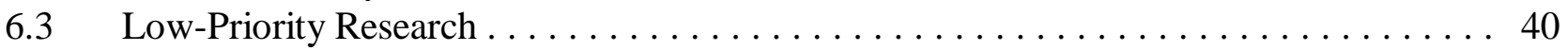

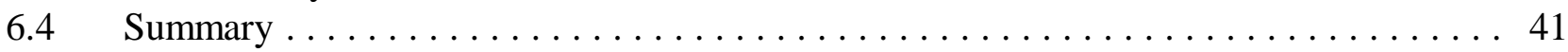

$7 \quad$ REFERENCES $\ldots \ldots \ldots \ldots \ldots \ldots \ldots \ldots \ldots \ldots \ldots \ldots \ldots \ldots \ldots \ldots \ldots \ldots$

APPENDIX A - STATUS OF BURNUP CREDIT PROGRAMS BY COUNTRY . . . . . . . . . 55 


\section{LIST OF FIGURES}

$\underline{\text { Figure }}$

$\underline{\text { Page }}$

$1 \quad$ Fraction of neutron absorptions versus cooling time for $4.5-\mathrm{wt} \%$-enriched PWR fuel

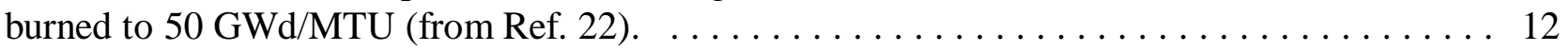

2 Fraction of neutrons absorbed by major actinides at various cooling times for 4.5-wt \%-

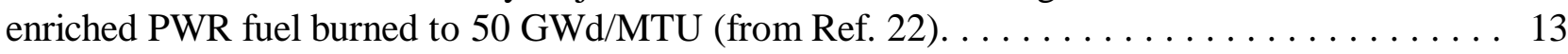

$3 \quad$ Fraction of neutrons absorbed for major fission products at various cooling times for 4.5-wt \%-enriched PWR fuel burned to $50 \mathrm{GWd} / \mathrm{MTU}$ (from Ref. 22). . . . . . . . . . . 14

$4 \quad$ Values of $k_{\text {eff }}$ for a generic rail cask as a function of burnup using different sets

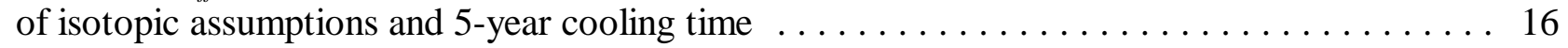

$5 \quad$ Schematic of $k_{\text {eff }}$ change with burnup for assemblies with and without absorber rods $\ldots \ldots \ldots 21$

$6 \quad$ Plot of $k_{\text {eff }}$ versus cooling time for various enrichments and burnup values (from Ref. 21) ..... 23 



\section{LIST OF TABLES}

\section{$\underline{\text { Table }}$}

Page

$1 \quad$ Comparison of regulatory requirements for PWR burnup credit criticality safety Assessments in pool storage, dry cask storage, and transport . . . . . . . . . . . . . 8

$2 \quad$ Most important nuclides in criticality calculations $\ldots \ldots \ldots \ldots \ldots \ldots \ldots \ldots$

$3 \quad$ OECD phase IA $\Delta k$ values (actinides are relative to fresh fuel) $\ldots \ldots \ldots \ldots \ldots \ldots$

$4 \quad$ Summary of information on depletion modeling parameters $\ldots \ldots \ldots \ldots \ldots \ldots$

$5 \quad$ Summary of proposed research objectives and activities $\ldots \ldots \ldots \ldots \ldots \ldots \ldots$ 



\section{INTRODUCTION}

In the past, criticality safety analyses for commercial light-water reactor (LWR) spent fuel storage and transport canisters $\frac{1,2}{4}$ ssumed the spent fuel to be fresh (unirradiated) fuel with uniform isotopic compositions corresponding to the maximum allowable enrichment. This "fresh-fuel assumption" provides a well-defined, bounding approach to the criticality safety analysis that eliminates all concerns related to the fuel operating history, and thus considerably simplifies the safety analysis. However, because this assumption ignores the decrease in reactivity as a result of irradiation, it is very conservative and can result in a significant reduction in spent nuclear fuel (SNF) capacity for a given package volume. References 3-5 and numerous ensuing publications have demonstrated that increases in SNF cask capacities from use of burnup credit can enable a reduction in the number of casks and shipments, and thus have notable financial benefits while providing a risk-based approach to improving safety. The concept of taking credit for the reduction in reactivity due to fuel burnup is commonly referred to as burnup credit. The reduction in reactivity that occurs with fuel burnup is due to the change in concentration (net reduction) of fissile nuclides and the production of actinide and fission-product neutron absorbers.

In contrast to criticality safety analyses that employ the fresh-fuel assumption, credit for fuel burnup necessitates careful consideration of the fuel operating history, additional validation of calculational methods (due to prediction and use of SNF nuclide compositions), consideration of new conditions or configurations for the licensing basis, and additional measures to ensure proper cask loading. For pressurized-water-reactor (PWR) fuel, each of these four areas have been studied in some detail over the last decade and considerable progress has been made in understanding the issues and developing approaches for a safety evaluation. However, a consensus has not been reached on how to answer such questions as: What constitutes adequate validation? How does one select the appropriate axial burnup profile for the licensing analysis? How should the variation/uncertainty in operating histories, fuel design, and SNF composition be quantified and incorporated in the safety analysis? This report will review the status of technologies related to burnup credit and identify the phenomena, technical issues, and related licensing considerations that need to be addressed in order to facilitate the implementation of burnup credit into the licensing of transport and storage casks.

A process called Phenomena Identification and Ranking Tables (PIRT) has been used by the NRC Office of Regulatory Research to identify phenomena and prioritize their importance in helping to resolve a broad technical issue. The purpose of this report is to provide a baseline document with which to initiate the PIRT process for burnup credit. Thus, this report will propose phenomena and technology issues deemed important to effective burnup credit implementation and propose a table that prioritizes the areas where technical resolution is needed. The phenomena and technology issues, as well as the ranking table, can be updated as additional input and feedback is obtained from industry and regulatory participants in the PIRT process. Although consensus on PWR issues may be achieved relatively quickly within the PIRT process, the current knowledge relative to the application of burnup credit for boiling-water-reactor (BWR) fuel or mixed-oxide (MOX) fuel will likely prolong consensusbuilding for those topics.

Section 2 of this report provides a review of the application areas where burnup credit has been, or is being, considered for use in the safety basis for operations. The purpose of this review is to provide some common understanding of the different approaches to help facilitate comparative discussions that may arise during the current PIRT process, which will focus on cask storage and transport. Section 3 presents a review of past and current technical studies related to burnup credit to help provide a background for the source of technical information included in this document. Section 4 discusses the parameters and physics issues identified as important to burnup credit implementation, while Section 5 discusses technical and licensing issues. Section 6 prioritizes the parameters, phenomena, and issues that need to be investigated and/or resolved to expedite implementation of burnup credit. Criteria used to establish the priorities are also discussed in Section 6. A recent 
evaluation of burnup credit programs by country and their relevance to the ensuing PIRT process is given in Appendix A. 


\section{REVIEW OF APPLICATION AREAS}

As indicated in the Introduction, this report and the ensuing PIRT process will focus on the implementation of burnup credit in dry cask storage and transport. However, an understanding of the manner in which the burnup of spent fuel has been considered in other applications may be beneficial - particularly since the implementation of burnup credit in spent fuel pools is significantly different than the methodology proposed and used to date in cask transport and storage. This section provides such a background review.

\subsection{Reactor Operations}

Accurate prediction and understanding of the changing nuclide inventory as a function of burnup is a necessity to safe and efficient operation of a nuclear reactor. Major efforts have been expended by the nuclear industry to ensure that the changing isotopic compositions of fuel assemblies in an operating reactor are properly accounted for and that effective analysis methods are available to "follow" and predict operating conditions for the reactor. Of primary interest is the integral effect (i.e., neutron multiplication) of the changing SNF inventory. The analytic methods used in reactor operations have traditionally been based on geometric and physics approximations (primarily applicability of neutron diffusion theory) to the Boltzmann radiation transport equation, but have been made increasingly reliable with continuous feedback experience (i.e., integral validation) gleaned from a 40-year period of operating commercial LWRs in a controlled environment. However, the analysis methods used for calculation of the effective neutron multiplication factor $\left(k_{e f f}\right)$ in commercial LWR operations are typically not applicable for out-of-reactor situations due to such problems as geometry modeling restrictions or the increased importance of angular scattering or leakage. In addition, the nuclide inventory provided by the reactor corefollowing codes has historically not included many of the nuclides important to prediction of $k_{\text {eff }}$ in out-of-reactor operations.

\subsection{Pool Storage}

Storage of spent fuel in underwater racks at reactors has been standard practice in the United States since the start of the nuclear industry. Spent fuel pools (SFPs) at reactors are licensed under 10 CFR 50 and represent a controlled facility operated in conjunction with the reactor operation. In lieu of credit for boron in the water, the NRC Office of Nuclear Reactor Regulation has licensed use of burnup credit for many years in borated SFPs at PWR plants. 6 The general approach used in the United States apparently seeks to blend the experience and reliability from the reactor core-following codes with the out-of-reactor analysis requirements for criticality safety (e.g., ANSI/ANS-8.17). The SNF inventory subsequent to decay of the short-lived ${ }^{135} \mathrm{Xe}$ isotope is typically used within a storage pool geometry to determine a fresh fuel enrichment that provides the same reactivity as the SNF inventory. This "equivalent" fresh fuel enrichment is then used within a criticality safety analysis code to perform the actual safety analysis for the pool. Little or no validation of the isotopic inventory prediction via comparison with SNF chemical assays is performed; instead, the reliability of the analysis approach in performing corefollowing calculations is considered to be adequate. Similarly, validation of the cross-section data, as typically provided by critical experiments, is limited to the fresh fuel nuclide inventory.

The current burnup credit approach for SFPs hinges on the adequacy of the process to determine the SNFequivalent fresh fuel assembly enrichment as well as the proper use of the equivalence information within environments that provide similar neutronic characteristics. Until recently, this general process had been used to obtain burnup credit in PWR SFPs where credit for the soluble boron is taken only for postulated accident events. Recently, however, credit for soluble boron up to $5 \%$ in reactivity has been allowed by the NRC 6 
Based on the information available to the authors of this report, true "burnup credit" for BWR storage pools (where there is no soluble boron) has not been licensed; instead, the approach has been to obtain an equivalent fresh fuel enrichment associated with the peak reactivity anticipated for the BWR fuel during the depletion process (reactivity initially increases early in life due to depletion of the gadolinium absorber in the assembly).

\subsection{Transport and Storage Casks}

The requirements for transport and dry storage (as opposed to wet storage in a pool) of SNF have their own set of regulations, which are included in 10 CFR 71 and 72, respectively. Both regulations are the responsibility of the NRC Office of Nuclear Material Safety and Safeguards. Neither regulation has any specific requirement that would prevent burnup credit from being implemented in the safety analysis. In the case of dry spent fuel storage, water in-leakage to the cask during storage is not considered credible; thus, burnup credit for PWR fuel is not typically necessary since the only flooded condition corresponds to fuel loading and unloading, where soluble boron in the water may be used for reactivity control. Soluble boron is not present in BWR SFPs, and thus for fuel loading or unloading at a BWR, negative reactivity associated with soluble boron is not available. However, the reactivity of BWR assemblies is less than that of PWR assemblies, and increased cask loadings have been accomplished to date without burnup credit.

At some point the spent fuel must be transported over public roads from the reactor to a common storage or permanent disposal location, and the regulatory practice for transport is that water in-leakage be considered in the evaluation of a single cask. Consequently, spent fuel canisters planned for use in transport must be shown to maintain adequate sub-criticality margin when flooded with fresh water. It is not desirable to have separate spent fuel canisters for storage and transport; thus canisters designed for use with both storage and transport casks (or overpacks), have become the standard industry practice. As a result, the regulatory requirements for transport directly impact storage practice. For example, it is not desirable to load spent fuel into a canister and seal-weld the canister for storage if the contents are not allowable for transport Therefore, the need for burnup credit in casks is driven by the regulatory requirements for transport.

Since 1985 significant effort has been devoted to investigating the operational merits (reduced number of shipments and cost savings) and technical issues (performance of safety analysis) associated with burnup credit for cask transport and storage of LWR spent fuel. The efforts have focused on PWR fuel with only scoping studies performed for BWR fuel. To date, there is no regulatory experience in the United States with licensing a LWR cask with burnup credit. However, the NRC has recently issued interim staff guidance (ISG87 7 which provides recommendations for implementing burnup credit in the safety analysis of PWR casks. The recommendations within ISG8 limit the burnup credit to that available from actinide-only nuclides for SNF with assembly-average burnup of $40 \mathrm{GWd} / \mathrm{MTU}$ or less and a cooling time of 5 years. The ISG8 recommendations allow spent fuel with burnup values greater than $40 \mathrm{GWd} / \mathrm{MTU}$ to be loaded in a cask, but burnup to only $40 \mathrm{GWd} / \mathrm{MTU}$ can be credited. Initial enrichments up to $5.0 \mathrm{wt} \%{ }^{235} \mathrm{U}$ (special provisions/penalties are required for enrichments beyond 4.0 wt $\%{ }^{235} \mathrm{U}$ ) are allowed. However, assemblies with burnable absorbers are not allowed. The approach to implementation of burnup credit in safety analysis for transport packages will involve predicting the nuclide inventory with a code that will provide adequate individual isotopic information for SNF and subsequent use of that inventory to determine the $k_{\text {eff }}$ value.

The ISG8 recommends that the analysis methods used to predict the SNF isotopics and $k_{\text {eff }}$ value be validated against measured data and that efforts be made to identify and/or bound potential uncertainties caused by variation in reactor operating histories, lack of measured data for validation, and the spatial variation of the burnup within the assembly (axial and horizontal). Further, the ISG recommends the use of a measurement prior to or during the 
loading procedure to ensure that each assembly is within the loading specifications for the approved contents (e.g, a burnup measurement). The recommendations for a bounding approach and pre-shipment measurements are consistent with the international regulations for transport of fissile materia 8 which directly address transport of irradiated nuclear fuel.

\subsection{Permanent Disposal}

Licensing requirements for permanent disposal of SNF at a proposed repository at Yucca Mountain are provided in 10 CFR 63. Proposed changes to the regulations allow the potential for criticality in the repository to be considered in light of the probability of occurrence and the consequences to the total system performance. The quantity of fissile material being considered for disposal together with the uncertainties associated with degradation and movement of the material over geological time frames makes this a practical approach that will provide safety to the public. Thus, the licensing approach ${ }^{9}$ being considered seeks to identify credible (above a certain probability of occurrence) configurations with a potential for criticality and explore the consequences that might result from such critical events. For intact fuel, the licensee is seeking to evaluate the configurations using SNF isotopic compositions that include both actinides and stable fission products. Additionally, burnup credit for both PWR and BWR fuel is being considered. The analysis and validation approach for disposal waste packages is more similar to that considered for transport casks than the approach used for SFPs.

\subsection{Discussion and Comparison of Approaches}

The approaches used to resolve a technical problem are typically based on historical precedence and experience in the subject area. In the United States, the need to consider burnup credit came initially to the SFPs, when the absence of disposal and reprocessing options caused the capacity requirements to continually exceed initial design expectations. Credit for burnup or soluble boron was needed to extend the pool capacity. At the time, the Advisory Committee on Reactor Safety considered potential loss of soluble boron to be of greater concern than any uncertainties associated with implementing burnup credit. Thus burnup credit was implemented in a fashion consistent with the analysis and operations experience within the reactor industry and NRC. Considerations for future implementation of the approach in out-of-reactor applications such as transport do not seem to have been considered.

Similarly, when efforts were initiated to consider burnup credit implementation in transport, the approach immediately sought to meet the requirements of the ANSI/ANS standards for criticality safety while extending the safety analysis to use a "bounding" spent fuel inventory. A comparison of the regulatory guidance for the criticality safety analyses of SNF storage in SFPs with that of SNF in transport reveals significant differences. The approach used for burnup credit in SFPs does not provide for a separate assessment of the individual sources of analysis uncertainty, but rather allows the presence of borated water and administrative controls to provide a necessary margin to eliminate the need for such an assessment. On the other hand, burnup credit criticality safety evaluations for dry storage and transport are required to assess individual sources of uncertainty and ensure consideration of these uncertainties in the safety evaluation. The reason for this difference may be attributed to the fact that the SFPs provide a protected, controlled environment within the confines of the reactor site where the fuel was typically used and where responsibility for safety resides. However, in transport, the licensed cask can be used in any facility and transported over public roads, where the environment is more unpredictable and the controls less reliable. 
The regulatory allowance of burnup credit in SFPs, including credit for fission products, seems to be partly justified 10 by the presence of soluble boron in the spent fuel pool. The reactivity margin associated with the soluble boron is inherently credited in SFP burnup credit analyses to account for uncertainties associated with the utilization of burnup credit. This approach is justified on the basis that there is typically sufficient soluble boron present in PWR SFPs (soluble boron concentrations of $\sim 2000 \mathrm{ppm}$ are common) to maintain subcriticality even if an entire storage rack intended to accommodate burned fuel were misloaded with fresh fuel assemblies of the highest allowable enrichment. Note that recent allowance for partial soluble boron credit (up to 5\%) reduces this associated margin.

Because of the reasons stated above, burnup credit criticality analyses for SFPs are not required to address the numerous issues that have been identified in the context of burnup credit for transportation. The following paragraphs briefly review the three major differences between the requirements for criticality safety analyses for SFPs and cask storage and transport. In the comparison noted below, which highlights the added constraints for burnup credit in transportation, the allowances for SFP analyses are all justified by the presence and control of soluble boron.

The first notable difference between the two NRC guidance documents for pool storag 6 and dry storage/transpor 7 is the selection of nuclides used in the implementation of burnup credit. SFP analyses are allowed credit for all nuclides except ${ }^{135} \mathrm{Xe}$ without explicit consideration of uncertainties in the calculated nuclide concentrations or assurance of their presence (e.g., fission gases). To account for uncertainties in fuel depletion calculations and nuclide presence, an uncertainty equivalent to $5 \%$ of the reactivity decrement to the burnup of interest (5\% of the reactivity reduction from fresh to the burnup of interest) is suggested as an acceptable assumption 6 In contrast, proposed burnup credit for dry storage and transpor 7 may credit only a subset of the available actinides present and must employ conservative isotopic biases determined from benchmarks of applicable fuel assay measurements. In addition, Ref. 7 limits the safety analyses to a single cooling time of 5 years while Ref. 6 allows consideration for all cooling times. Thus, SFP analyses are allowed $95 \%$ credit for the reduction in reactivity associated with all of the calculated isotopics (except ${ }^{135} \mathrm{Xe}$ ), but analyses for a transport application currently allow only a limited number of actinides and must substantiate the uncertainty in their prediction via comparison with measurement.

In regard to depletion calculations, no clear guidance or requirements for bounding depletion parameters, similar to those suggested in Ref. 11, exist for SFP analyses. Assemblies that used fixed burnable absorber rods (e.g., burnable poison rods and axial power shaping rods) are currently allowed to assume burnup credit in SFPs. In addition, assemblies with integral burnable absorbers (e.g., integral fuel burnable absorber and $\mathrm{UO}_{2} / \mathrm{Gd}_{2} \mathrm{O}_{3}$ rods) are allowed in SFPs. Allowance of burnup credit for assemblies with burnable absorber rods or integral burnable absorbers is not recommended in the current guidance for dry storage and transport 7

The second major distinction between the approach used in SFPs and that currently proposed for transport and dry storage is that the safety evaluation for SFPs use fresh fuel with a reactivity determined to be equivalent to spent fuel at a specified burnup. Uncertainties are associated with this approach in terms of the effect on the neutron spectrum (and associated reactivity worth of the poison material) and the geometric conditions under which the equivalency may be valid. For example, the fresh fuel equivalent for SNF in unborated water will be different than that in borated water. Other illustrations, perhaps extreme, of the uncertainties and concerns have been documented 12 The finite geometry of a cask in comparison to the near-infinite geometry of an SFP leads to significant differences in reactivity depending on the location of the assembly within the cask, thus making the reactivity equivalence approach inadequate for use in cask analysis. Instead, the criticality safety analyses for transport and dry storage are currently required to use an SNF nuclides predicted using codes and data validated against measured isotopic information. Furthermore, the analysis methodologies for calculating $k_{\text {eff }}$ must be validated for the specific nuclides that are credited. 
The recommendations of ISG8 note that the axial and horizontal variation of burnup within an assembly merit special consideration be given to the spatial variation of the SNF nuclide inventory such that conservative estimates of $k_{\text {eff }}$ are determined in the analysis. Modeling for SFP analyses typically assume uniform axial burnup (modeled as equivalent fresh fuel), and thus are required to determine and include a reactivity penalty associated with the axial burnup distribution 6 This penalty is determined based on the comparison of a calculation with uniform axial burnup (using equivalent enrichment) and a calculation with axial distributed burnup (using equivalent enrichments for each axial zone). Unlike analyses for transport and dry storage, use of a bounding axial burnup distribution is not required. Further, there are currently no requirements related to horizontal burnup distributions for SFP burnup credit criticality safety assessments.

The third significant distinction between burnup credit application in SFPs and transport and storage casks is that verification of assembly burnup through measurement is recommended prior to cask loading but administrative confirmation procedures are acceptable for SFP storage. In both cases, the assembly burnup value used for comparison to the loading criteria is a percentage of the reactor record burnup value. Although variations among utilities are believed to exist, the assembly burnup value used for establishing acceptance for SFP storage is typically between 90 and $95 \%$ of the reactor record value. For transport and dry storage, the percentage of the reactor record burnup value will be determined based on comparisons to measurements that can be related to the burnup.

The comparison between the burnup credit approaches for SFPs and transport or storage casks is summarized in Table 1. These differences can be attributed to (1) the controlled environment and presence of soluble boron in PWR SFPs and (2) the regulatory requirement to consider in-leakage of fresh water in a transport cask. A change in either of these situations would probably alter the approaches and/or need for implementing burnup credit within the associated application.

To date the only country that has approved transport casks for use with burnup credit has been France. Unlike the United States, the French have used virtually identical approaches for applying burnup credit in storage pools and in transport casks: the minimum burnup as averaged over any contiguous 50-cm segment of the fuel is applied as a uniform burnup over the entire fuel length, and only the uranium and plutonium isotopes are considered. The advantage of using the same technical approach for all applications (SFPs, transport, storage, etc.) is that it allows an effective interface of the safety evaluations between the application areas. 
Table 1 Comparison of regulatory requirements for PWR burnup credit criticality safety assessments in pool storage, dry cask storage, and transport

\begin{tabular}{|c|c|c|}
\hline \multirow[t]{2}{*}{ Issue } & \multicolumn{2}{|c|}{ Regulatory guidance } \\
\hline & Spent fuel pools ${ }^{a}$ & Transport and dry storage ${ }^{b}$ \\
\hline Nuclides credited & $\begin{array}{l}\text { All nuclides except }{ }^{135} \mathrm{Xe} \text {, with } \\
\text { depletion uncertainty equal to } 5 \% \\
\text { of the reactivity decrement }\end{array}$ & $\begin{array}{l}\text { Select actinides-only, with } \\
\text { conservative biases applied to the } \\
\text { concentrations. }\end{array}$ \\
\hline Modeling - fuel & Equivalent fresh fuel enrichments & Explicit isotopic content \\
\hline $\begin{array}{l}\text { Modeling - burnup } \\
\text { distributions }\end{array}$ & $\begin{array}{l}\text { Consideration of axial burnup } \\
\text { distribution }\end{array}$ & $\begin{array}{l}\text { Bounding consideration of axial and } \\
\text { horizontal burnup distributions }\end{array}$ \\
\hline $\begin{array}{l}\text { Validation } \\
\text { requirements }\end{array}$ & $\begin{array}{l}\text { Criticality code validation with fresh } \\
\text { fuel isotopics }\end{array}$ & $\begin{array}{l}\text { Validation of criticality and depletion } \\
\text { methodologies for the specific } \\
\text { isotopics credited }\end{array}$ \\
\hline $\begin{array}{l}\text { Maximum allowable } \\
\text { burnup }\end{array}$ & None specified & $\begin{array}{l}\text { No credit for burnup beyond } \\
\quad 40 \mathrm{GWd} / \mathrm{MTU}\end{array}$ \\
\hline $\begin{array}{l}\text { Maximum allowable } \\
\text { initial enrichment }\end{array}$ & $5.0 \mathrm{wt} \%{ }^{235} \mathrm{U}$ & $\begin{array}{l}4.0 \mathrm{wt} \%{ }^{235} \mathrm{U} \\
\qquad(5.0 \mathrm{wt} \% \text { with offset penalty) }\end{array}$ \\
\hline $\begin{array}{l}\text { Fixed burnable } \\
\text { absorbers }\end{array}$ & Acceptable & $\begin{array}{l}\text { Perhaps unclear from the text, but } \\
\text { intended to be not acceptable }\end{array}$ \\
\hline $\begin{array}{l}\text { Integral burnable } \\
\text { absorbers }\end{array}$ & Acceptable & Not acceptable \\
\hline $\begin{array}{l}\text { Requirement for } \\
\text { burnup } \\
\text { measurements }\end{array}$ & No & Yes \\
\hline Cooling time & All cooling times allowed & 5-year cooling time \\
\hline
\end{tabular}

${ }^{a}$ Guidance per Ref. 6.

${ }^{b}$ Guidance per Ref. 7. 


\section{REVIEW OF TECHNICAL STUDIES}

Financial and safety benefits to the U.S. nuclear industry were identified in the mid-1980s (see for example, Refs. 3 and 13) and have motivated technical studies directed at understanding the phenomena and parameters important to implementation of burnup credit for transport of PWR spent fuel. The United States has been an international leader in seeking to understand and address burnup credit technical issues (at least analytically), but significant work has been done in collaborative international studies. Studies initiated outside the United States are continuing to increase, largely spawned by a need for burnup credit to allow existing casks to transport fuel with higher initial enrichments. The available literature related to burnup credit likely consists of several hundred to more than a thousand journal articles, conference papers, and reports. The purpose of this section is to identify the major efforts that, to date, have provided the key sources of technical information pertinent to this report.

\subsection{Studies in the United States}

Prior to 1976, casks in the United States were designed to transport SNF with very short cooling times (90 days). Since that time the U.S. policy has shifted from one of reprocessing shortly after discharge to one of permanent disposal in a repository after long decay times in an SFP. With short cooling times the contents and capacity of an SNF transport cask are typically limited by thermal and shielding constraints; however, for long-cooling times the decay heat and radiation source terms are reduced to the point that criticality safety becomes a constraining limitation if fresh fuel isotopics are used. Thus, the DOE Office of Civilian Radioactive Waste Management (OCRWM) initiated a program to investigate the use of burnup credit as a means to significantly enhance the capacity of a transport package. Following preliminary studies by both DOE $\mathrm{E}^{3}$ and the Electric Power Research Institute (EPRI) 13 a workshop to present and discuss the issues was held in 1988 (Ref. 4), where DOE, EPRI, utilities, cask vendors, national laboratories, and the NRC all participated. Although the approaches and degree of sophistication have evolved, many of the burnup credit issues that are still under discussion today (e.g., axial effects, depletion modeling parameters, etc.) were presented and discussed at that workshop. Subsequent to the workshop, the DOE instigated a major effort to identify and resolve technical issues related to the safety analysis, operational procedures and facility interface (e.g., pre-shipment measurement), and optimization of PWR casks designed for burnup credit. EPRI and the utilities collaborated with the DOE, selected cask vendors, and national laboratories in an attempt to develop the technical basis and safety analysis approach for implementing burnup credit. After several technical exchanges with the NRC staff, the DOE moved forward with a topical report11 that was initially submitted in 1996 and subsequently revised in 1997 and 1998. The predominance of the United States literature to date has been developed as either background studies performed for, or in direct support of, the DOE and EPRI efforts to have burnup credit approved for PWR transport packages. Although the DOE topical repor 11 provides a good compendium of the technical literature, it is not exhaustive. More recently, the DOE effort to implement burnup credit within their topical repor ${ }^{9}$ on criticality methodology for the repository has provided additional information on burnup credit as applied to BWR spent fuel.

\subsection{International Activities}

In the United States the number of packages for SNF are relatively small in comparison with the numbers used in countries such as the United Kingdom, France, Germany, and Japan, where reprocessing has been practiced. With an existing fleet of casks and shorter cooling times that constrain design options, these countries have been less interested in increasing capacity for new designs than in increasing allowable fresh fuel enrichments for existing cask designs. A review of the current status of burnup credit work in each of these countries as it pertains to the PIRT process is provided in Appendix A. 
In 1991 the Nuclear Energy Agency of the Organization for Economic Cooperation and Development (OECD/NEA) initiated a Working Group tasked with the study of burnup credit issues. The Burnup Credit Working Group (BUCWG) defines and analyzes computational benchmarks for the purpose of an international comparison of different computer code/data packages when used in the study of spent fuel analysis. $14-18$ There has been significant interest in the BUCWG with active participation from the regulatory agencies, industry, and research organizations of nine countries. The large number of international participants has allowed comparison and study of a wide range of codes, data, and methods for each benchmark problem. To date, the BUCWG has studied a number of different configurations relevant to burnup credit in light-water reactors. In many cases these studies have only confirmed the findings of previous studies performed separately in the United States and other countries. In addition, the BUCWG has also provided a forum for discussing and understanding various approaches to the technical issues.

In 1997 the International Atomic Energy Agency (IAEA) began a task to monitor the implementation of burnup credit in spent fuel management systems as a means to provide a forum for exchanging information on the national practices. An excellent summary and country-by-country report of burnup credit implementation in SFPs, transport and dry storage, and permanent disposal is provided in Ref. 19. The IAEA is planning a Technical Committee Meeting for July 2000 to update information on implementation efforts, to allow presentations on regulatory and validation issues, and to provide time for active discussions and development of recommendations via work groups on each area (SFPs, transport, and disposal) 20

In 1991 when the BUCWG was formed, there was a handful of papers relevant to burnup credit at the International Conference on Nuclear Criticality (ICNC). The heightened international work interest in burnup credit is evidenced by the fact that there were more than 20 papers related to burnup credit at the recent ICNC' 99 meeting. The work being performed by the international community provides a ready source of valuable information for improved technical understanding, confirmation of findings, and different views to the same issues. 


\section{PARAMETER AND PHENOMENA IDENTIFICATION}

The purpose of this section is to identify the characteristic parameters and physics phenomena that are important to understanding burnup credit and review the current knowledge as gleaned from the activities described in Section 3. A discussion of unresolved issues associated with each parameter or phenomenon is also provided, particularly as it relates to the current NRC guidance embodied within ISG8. The degree of resolution achieved and/or needed can be a subject of some debate - as will likely occur during the PIRT process.

\subsection{Nuclides Important to Burnup Credit}

Spent nuclear fuel contains hundreds of unique nuclides. The actual reactivity worth of the fuel is a function of the net neutron production and absorption by all nuclides present. However, if criticality calculations are performed based on all fissile nuclides and a limited subset of absorbers, the value of $k_{\text {eff }}$ calculated is conservative. To date, the approach proposed for burnup credit in storage and transport casks has been to qualify calculated isotopic predictions via validation against destructive assay measurements from SNF samples. Thus, utilization of nuclides in the safety analysis process has been limited based on the availability of measured assay data and chemical characteristics (e.g., volatility) that might cause the nuclide to escape the fuel region. 21

Several studies have been performed to identify the nuclides which have the most significant effect on the calculated value of $k_{\text {eff }}$ as a function of burnup and cooling time $3,21,22$ Figures 1-3 provide the results of one study 22 which performed a relative ranking based on the fraction of total absorptions for each nuclide. The adequacy of this simple ranking approach has been confirmed with more rigorous approaches that obtained the actual change in $k_{\text {eff }}$ for an infinite lattice of rods based on a change in each nuclide.21] The relative worth of the nuclides will vary some with fuel design, initial enrichment, and cooling time, but the important nuclides remain the same. A recent study for BWR spent fuel also indicates the ranking of important nuclides changes only slightly in going from PWR to BWR operating conditions 23 Figures 1-3 indicate that the majority of neutron absorption is caused by only a few actinide isotopes and, individually, the fission products contribute much less to neutron absorption. For cooling times of interest to transport and dry cask storage (2 to 100 years), Figures 2-3 indicate that the relative importance of only a few nuclides change significantly with cooling time. The buildup of ${ }^{155} \mathrm{Gd}$ and ${ }^{147} \mathrm{Sm}$ from the decay of other non-absorbing fission products and the decay of ${ }^{241} \mathrm{Pu}\left(14.4 \mathrm{y}\right.$-half-life) to ${ }^{241} \mathrm{Am}$ contribute to the decrease in $k_{\text {eff }}$ as cooling time increases. The effect of the decay of ${ }^{151} \mathrm{Sm}$ appears to be compensated by the commensurate buildup of ${ }^{151} \mathrm{Eu}$. Based on these and other studies, the nuclides listed in Table 2 are considered to be the prime candidates for inclusion in burnup credit analyses related to dry storage and transport. Obviously, ${ }^{151} \mathrm{Sm}(90-\mathrm{y}$ half-life) and ${ }^{151} \mathrm{Eu}$ are a pair, and ${ }^{151} \mathrm{Eu}$ only needs to be considered if the absorption credit for ${ }^{151} \mathrm{Sm}$ must be maintained. [Note that although it is a relatively minor absorber, many previous studies have included ${ }^{135} \mathrm{Cs}$ in their analyses because measured isotopic data currently exist. Although it can be included in a burnup credit analysis, its effect on cask reactivity is negligible?

Table 2 Most important nuclides in criticality calculations

\begin{tabular}{llllll}
\hline${ }^{234} \mathrm{U}$ & ${ }^{235} \mathrm{U}$ & ${ }^{236} \mathrm{U}$ & ${ }^{238} \mathrm{U}$ & ${ }^{238} \mathrm{Pu}$ & ${ }^{239} \mathrm{Pu}$ \\
${ }^{240} \mathrm{Pu}$ & ${ }^{241} \mathrm{Pu}$ & ${ }^{242} \mathrm{Pu}$ & ${ }^{241} \mathrm{Am}$ & ${ }^{243} \mathrm{Am}^{*}$ & ${ }^{237} \mathrm{~Np}$ \\
${ }^{95} \mathrm{Mo}$ & ${ }^{143} \mathrm{Tc}$ & ${ }^{101} \mathrm{Ru}^{*}$ & ${ }^{103} \mathrm{Rh}^{*}$ & ${ }^{109} \mathrm{Ag}^{*}$ & ${ }^{133} \mathrm{Cs}$ \\
${ }^{151} \mathrm{Eu}^{*}$ & ${ }^{145} \mathrm{Nd}$ & ${ }^{147} \mathrm{Sm}$ & ${ }^{149} \mathrm{Sm}$ & ${ }^{150} \mathrm{Sm}$ & ${ }^{151} \mathrm{Sm}$ \\
\hline
\end{tabular}

*Nuclides for which measured chemical assay data is not currently available in the United States. 
- Actinide Absorption Fraction

- Fission-Product Absorption Fraction $\quad$ - Total Absorptions $\longrightarrow$

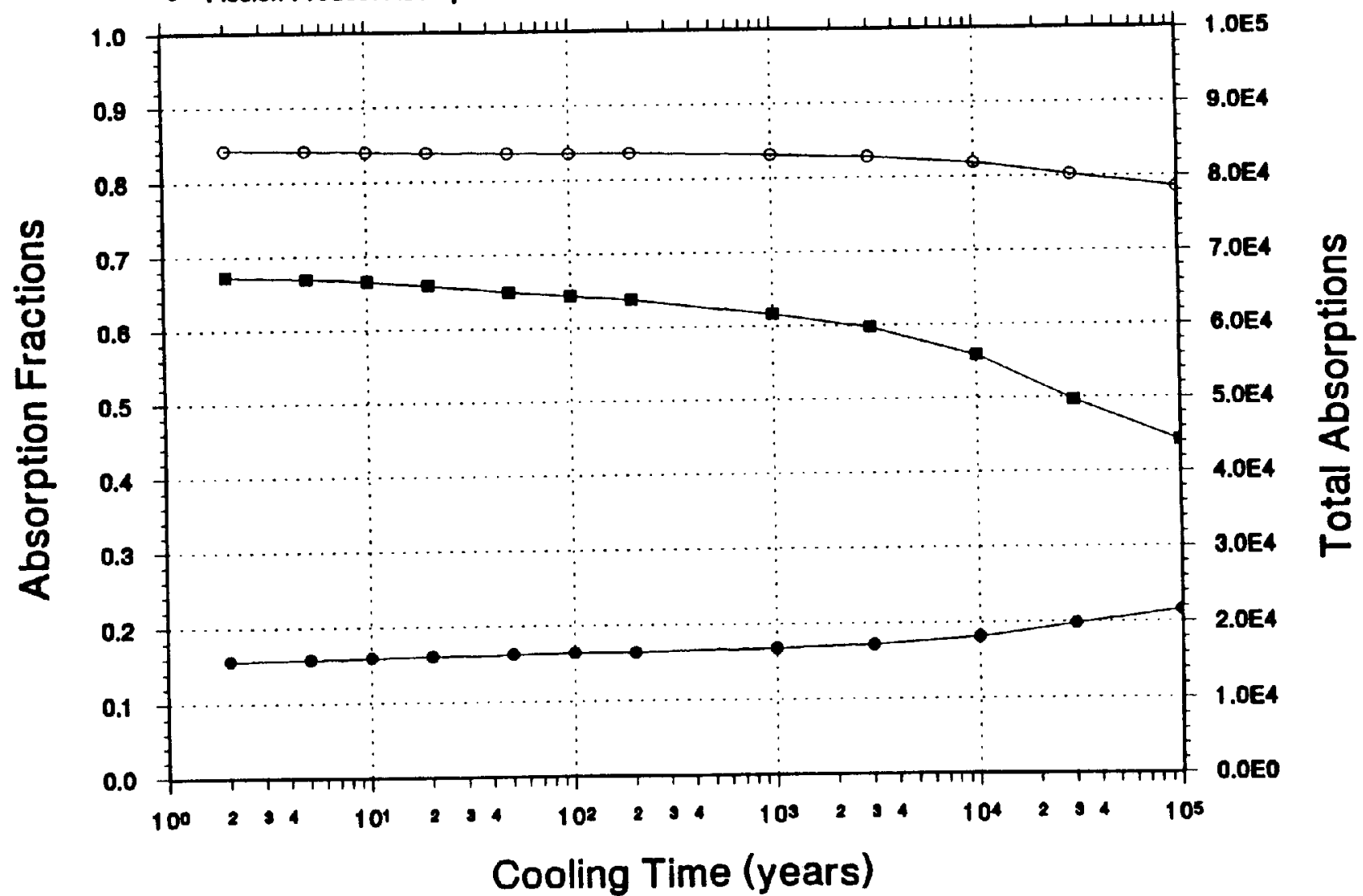

Figure 1 Fraction of neutron absorptions versus cooling time for 4.5 -wt $\%$-enriched PWR fuel burned to $50 \mathrm{GWd} / \mathrm{MTU}$ (from Ref. 22) 


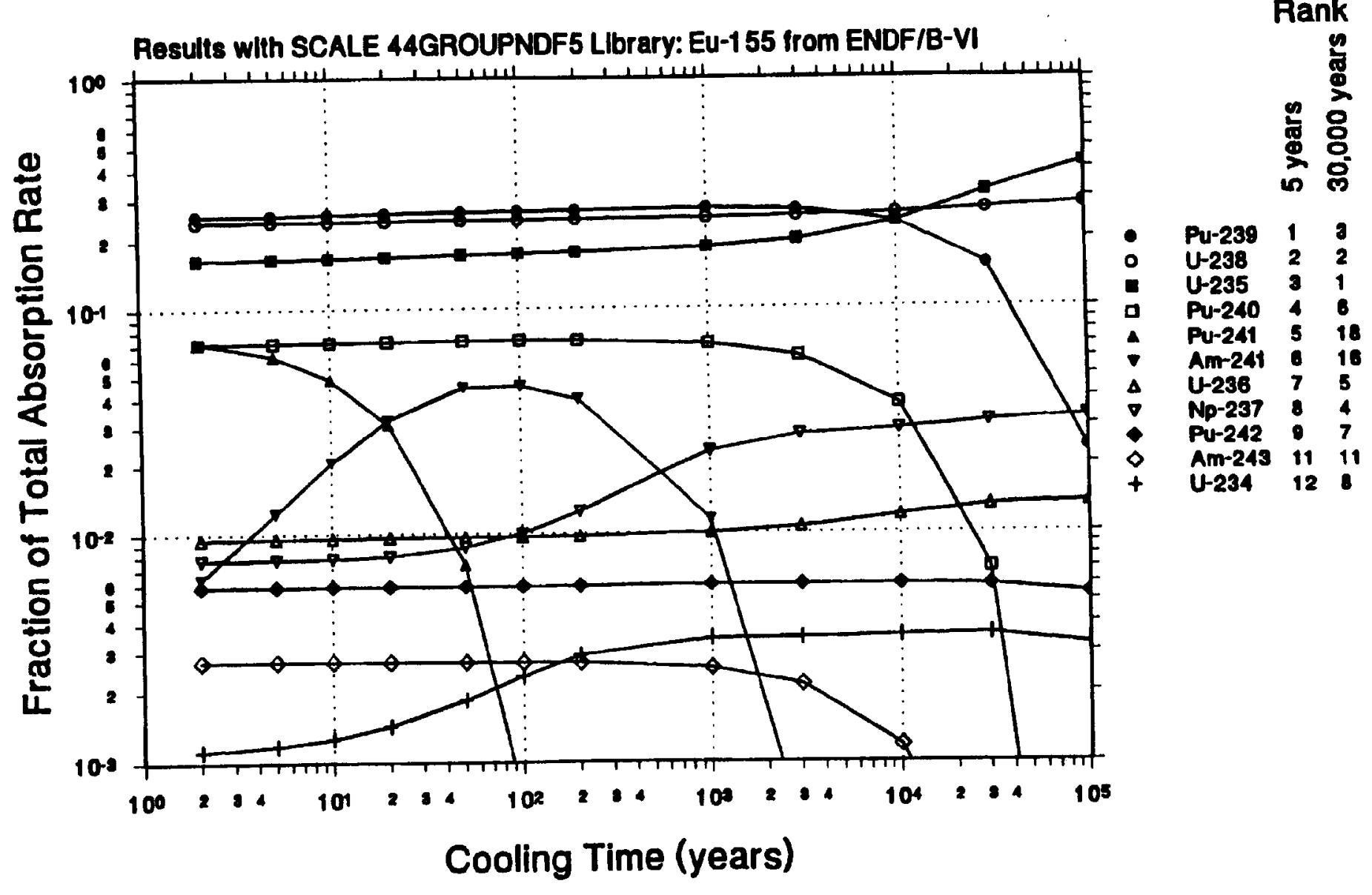

Figure 2 Fraction of neutrons absorbed by major actinides at various cooling times for 4.5 -wt $\%$-enriched PWR fuel burned to $50 \mathrm{GWd} / \mathrm{MTU}$ (from Ref. 22) 


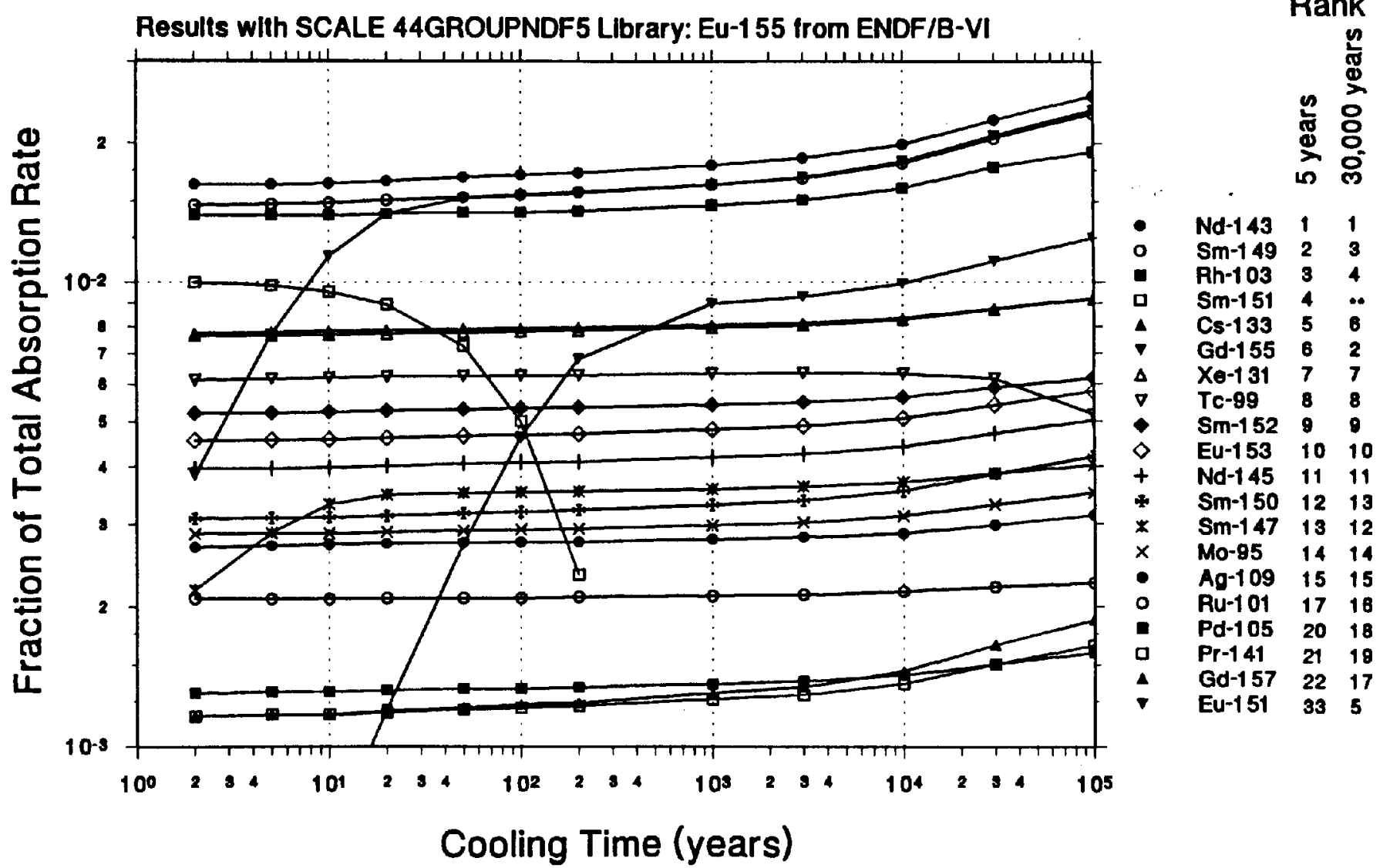

Figure 3 Fraction of neutrons absorbed for major fission products at various cooling times for 4.5 -wt \%enriched PWR fuel burned to 50 GWd/MTU (from Ref. 22) 
As indicated earlier, validation of calculated isotopic predictions against experimental measurements is desirable for any nuclide upon which burnup credit criticality calculations are based. Isotopic validation studies using the SCALE/SAS2H depletion sequence and available measured assays have been performed for PWR spent fue 24,25 and BWR spent fuel ${ }^{26}$ For BWR fuel, the number of nuclides for which there are measured data is significantly reduced and is limited primarily to the actinides of Table 2.26 For the most part, the fission product measurements available in the United States for PWR fuel is limited to 3-6 measurements, and prediction methods for these nuclides may not be considered to be fully validated. This situation is the major reason that only partial or "actinide-only" burnup credit was considered in the DOE topical repor 11 and the ISG8 7 The fission product margin is still present, but since sufficient measured data for isotopic validation do not exist, credit for its negative worth has not been recommended for inclusion in safety analyses.

Table 3 shows the participant-averaged incremental worth of actinides and fission products as determined by the OECD/NEA BUCWG in a study 15 involving an infinite lattice of fuel pins with an initial enrichment of $3.6 \mathrm{wt} \%$ ${ }^{235} \mathrm{U}$ and nuclides nearly identical to those of Table 2 . The results of Table 3 indicate that for these burnup values the reactivity decrease is roughly $2 / 3$ due to actinides, another $1 / 3$ due to fission products. This finding is consistent with earlier worl ${ }^{27}$ for infinite lattices. However, it is important to remember that the competing effect of external absorbers in cask designs will change this ratio for finite cask analysis resulting in the fission products with less relative worth. This reduced effect is seen in Figure 4, which is based on a generic rail cask design with 5-year cooled fuel. This figure shows the reactivity worth of the eleven actinides with measured assay data as identified in Table 2 in comparison to the additional worth that can be obtained from: fission products with measured assay data as identified in Table 2, all the nuclides of Table 2, and all nuclides (approximately 230) for which cross-section data are available in ENDF/B-V. The fission products provide less than $1 / 4$ of the total reactivity decrease for this particular cask design.

Table 3. OECD phase IA $\Delta k$ values (actinides are relative to fresh fuel)

\begin{tabular}{llcc}
\hline & & $30 \mathrm{GWd} / \mathrm{MTU}$ & $40 \mathrm{GWd} / \mathrm{MTU}$ \\
\hline 1-year cooled & Actinides & 0.1922 & 0.2492 \\
& Fission products & 0.1054 & 0.1248 \\
& Total & 0.2976 & 0.3740 \\
\hline 5-year cooled & Actinides & 0.2094 & 0.2721 \\
& Fission products & 0.1161 & 0.1417 \\
& Total & 0.3255 & 0.4138 \\
\hline
\end{tabular}

Based on Figure 4, it is not likely that additional work to extend the nuclides used in burnup credit beyond that identified in Table 2 would be warranted. However, identification and understanding of the additional margin available from the SNF inventory not listed in Table 2 may be beneficial. 


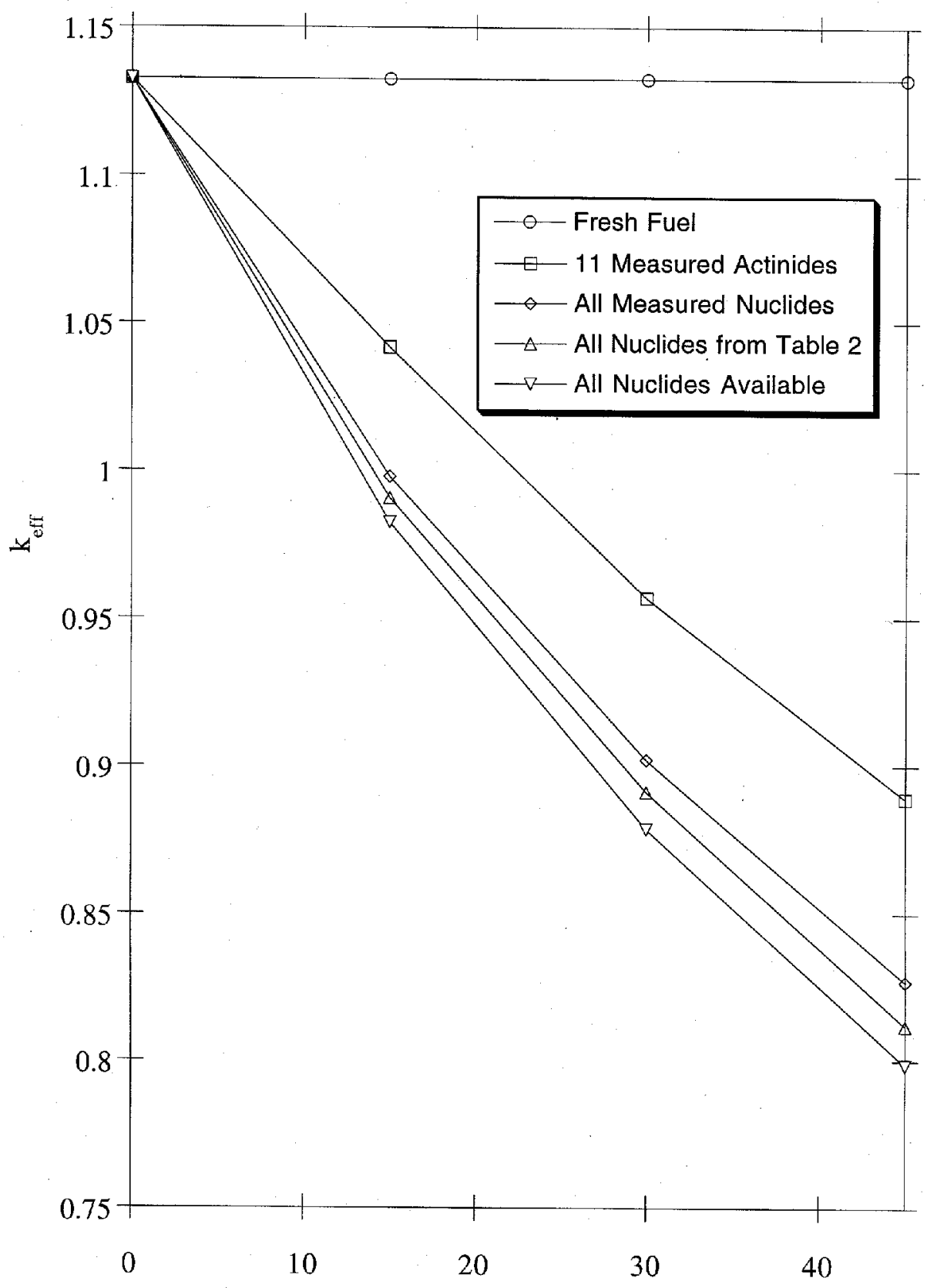

Burnup (GWd/MTU)

Figure 4 Values of $k_{\text {eff }}$ for a generic rail cask as a function of burnup using different sets of isotopic assumptions and 5-year cooling time 


\subsection{Parameters for Depletion Analysis}

It is anticipated that burnup credit will be applied for a wide variety of fuel types, each irradiated under a variety of reactor operating conditions (temperature, PWR boron concentration, BWR blade/fixed poison usage, etc.). If a cask design is intended to accept such a variety of fuel, assumptions that encompass the known variations must be employed in the depletion calculations to ensure that the nuclide content of the fuel is conservatively

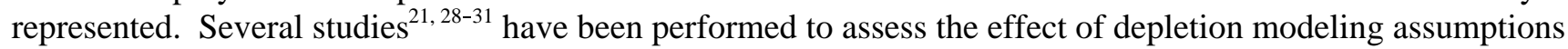
on SNF nuclide predictions. In these parametric analyses, calculated nuclide concentrations were used to calculate $k_{\text {eff }}$ for infinite SNF pin lattices and generic casks loaded with SNF. Trends in the neutron multiplication were then examined as a function of each parameter to determine the conservative direction (e.g., high temperature vs low temperature) for that parameter, and the magnitude of the effect over a realistic operating range.

For each parameter studied in Refs. 21 and 28-31, the sensitivity of the neutron multiplication to changes in the parameter increase with higher burnups. Furthermore, with the exception of specific power/operating history effects, all of the trends discussed below are related to spectral hardening. Spectral hardening results in an increased production rate of plutonium from increased fast neutron capture in ${ }^{238} \mathrm{U}$. Enhanced plutonium production and the concurrent diminished fission of ${ }^{235} \mathrm{U}$ due to increase plutonium fission has the effect of increasing the reactivity of the fuel at discharge and beyond. The exact mechanisms that result in spectral hardening for various operating conditions are discussed in each of the following subsections. Specific power and operating history effects are driven instead by the balance of the various equilibrium states of the nuclides present, as a function of power. These effects are described in more detail in Sect. 4.2.4.

In practice, an operational extreme in one parameter may result in an opposite extreme for a coupled parameter. However, simultaneous use of realistic bounding parameter values in a depletion model provides a simple, prudent approach to the modeling process since it is unlikely that any fuel would be depleted under all such conditions simultaneously.

\subsubsection{Fuel Temperature}

Studies of both BWR and PWR depletion models, $21,8-31$ show a clear trend for increased conservatism (i.e., increase in $k_{\text {eff }}$ value) as the assumed fuel temperature during operation is increased. It is believed that at higher fuel temperatures, resonance absorption in ${ }^{238} \mathrm{U}$ is increased due to Doppler broadening, resulting in spectral hardening and increased plutonium production. The effect is burnup dependent, increasing linearly with increasing burnup. Thus, conservative SNF nuclide inventories are predicted by assuming an upper estimate of fuel temperature during depletion calculations. The bounding case is for high-burnup fuel and Ref. 21 shows that the reactivity worth of temperature change is on the order of $5 \mathrm{pcm} / \mathrm{K}\left(\mathrm{pcm}=\right.$ percent mill $\left.=10^{-5} \Delta k / k\right)$ for an infinite lattice of PWR fuel pins and $4 \mathrm{pcm} / \mathrm{K}$ for a generic cask 28 Ref. 30 shows similar behavior for infinite lattice of BWR fuel. Thus, use of the maximum pellet-averaged temperature in the depletion analysis should be acceptable for PWR and BWR depletion analyses. Although a value of $1000 \mathrm{~K}$ would seem appropriately conservative to cover normal PWR reactor operations, a reference industry report establishing a defensible value for PWR and BWR operations would be beneficial to facilitate future safety analyses. 


\subsubsection{Moderator Temperature/Density}

As with fuel temperatures, calculations performed with varying moderator temperatures show that nuclide compositions are most conservative with respect to neutron multiplication when calculated assuming an upper bound on moderator temperature (e.g., core outlet temperature). 21. 28-31] Although the mechanisms are different, the net effect is the same. In a PWR, as the moderator temperature increases, the moderator density decreases. Decreased density results in reduced moderation, which result in higher average energy neutrons and spectral hardening. The response is close to linear, but has a slight exponential shape with increasing moderator density (due to the fact that water density is not linear with respect to temperature). The reactivity effect also increases with increasing burnup. For the bounding case of high-burnup fuel, Ref. 21 shows a reactivity worth of about $90 \mathrm{pcm} / \mathrm{K}$ for an infinite lattice of PWR fuel pins and Ref. 28 indicates $35 \mathrm{pcm} / \mathrm{K}$ in a cask environment. In general, however, the variation in temperature and corresponding density is relatively small in a PWR design. Thus, use of the maximum core outlet temperature (e.g., $600 \mathrm{~K}$ ) is recommended; however, a reference industry report that would help establish the limiting value for normal (and perhaps off-normal) reactor operations would be beneficial.

Spectral hardening resulting from decreased moderator density is intentionally applied in the control of a BWR. However, the net effect is unchanged from the effect discussed for PWR designs. In BWR systems, moderator temperatures change very little axially once boiling begins in the flow channel. However, reactor operation allows significant variation in axial moderator density as the void fraction increases with increasing height. The void fraction can change significantly both axially and as a function of time. Hence, it is more instructive to study depletion effects as a function of moderator density rather than moderator temperature. Reference 30 demonstrates that for an infinite lattice of BWR assemblies, $k_{\text {inf }}$ increases linearly with decreasing moderator density and the trend is more pronounced as the SNF burnup increases. The magnitude of the effect is on the order of $10^{3} \mathrm{pcm} /\left(\mathrm{g} / \mathrm{cm}^{3}\right)$ for high burnup fuel. Thus, the highest average void fraction (minimum average moderator density) would appear to be the simple, bounding value to use for depletion analysis of BWR fuel. Since the reactivity of BWR fuel in a cask is driven by the fuel at the top of the assembly, it is anticipated that using the highest average void fraction should be a prudent, yet practical assumption for the safety analysis. However, additional work in this area may be warranted to substantiate the initial findings, and an industry report that provided an appropriate value for the maximum average void fraction under normal operations would be beneficial.

\subsubsection{Soluble Boron}

Soluble boron is used to control excess reactivity in PWRs. Soluble boron concentrations of 1000-1500 ppm boron are typical at beginning-of-cycle and decrease to 0-200 ppm at end-of-cycle. Depletion calculations may model the boron change in steps, or assume an average boron concentration for a full cycle. Studies have been performed to assess the effect of the soluble boron concentration used during depletion.21 28,31,32 The results of these bounding high-burnup calculations show a clear linear increase in reactivity with increased boron concentration at a rate of approximately $3 \mathrm{pcm} / \mathrm{ppm}$ for an infinite lattice of pins and $3.5 \mathrm{pcm} / \mathrm{ppm}$ in a cask configuration. Again, although the mechanism is different from that which occurs in fuel and moderator temperature variations, the end result is the same. Spectral hardening results from the absorption of thermal neutrons in the moderator by the soluble poison. As with temperatures, the effect of higher boron concentrations is more significant with higher burnup values, since more conversion occurs over the fuel cycle. Use of an average cycle boron value of $750 \mathrm{ppm}$ should be adequately bounding based on the studies performed; however, analyses that compare the use of an average value versus actual let-down curves would be informative. Also, establishment of a bounding value for the maximum average boron per cycle based on boron let-down curves would enable more straightforward application of the depletion analyses. 


\subsubsection{Specific Power and Operating History}

The effect of various operating histories (variations in specific power with time) on the reactivity of spent fuel

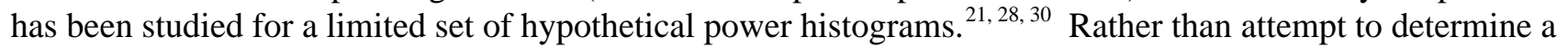
real operating history that would bound all other operating histories, histograms were developed to represent the key aspects of operating histories (e.g., extended downtime early in life, extended downtime late in cycle, highpower operation early in life, short intercycle downtimes, long intercycle downtimes, etc.). Results showed a wide variability in response due to the significantly different decay rates and equilibrium concentrations for the nuclides studied. In general, low-power operation near the end of cycle produces the highest reactivity due to decreased fission product inventory. However, the opposite is true when only actinides are considered for burnup credit - high-power operation is more conservative at end of life. Fission product worth is more sensitive to specific power than that of actinides; thus, when both are present, the net effect is driven by fission product behavior. Hence low-power operation toward end of life yields the most conservative estimate of reactivity. The net effect is rather small, up to $0.2 \% \Delta k / k$ for the operating histories considered. It appears that the optimum approach would be to assume a simple continuous-power operating history, and add in a margin to account for operating-history-induced effects.

The effect of specific power assumed during depletion calculations has also been studied independently of operating history for PWRs. ${ }^{21,28}$ Although an operating history is simply a time-varying specific-power profile, it is important to understand the effect of the magnitude of specific power when held constant with time.

Calculations with both actinide and fission product credit show a trend for conservative prediction of fuel reactivity worth when fuel is burned at lower specific power for a longer period of time for a given burnup. The magnitude of the conservatism increases with increasing burnup. However, the opposite is true for calculations in which only actinides are considered in criticality calculations. For actinide-only credit, higher specific powers result in the most conservative set of isotopics. The magnitude of the conservatism also increases with increasing burnup. The difference in behavior between actinides and fission products is due to the relatively short decay times of fission product precursors relative to actinides. An industry report that would help establish the range of specific powers for normal (and perhaps off-normal) reactor operations would be beneficial.

Recent work ${ }^{30}$ has shown that for high-burnup fuel with fission products present, the behavior of the SNF neutron multiplication as a function of specific power departs from a linear response. For high-burnup fuel, the neutron multiplication initially increases with increasing specific power, before turning (e.g., in the range of 10-20 MW/MTU) and decreasing as specific power continues to increase. Thus, there is a specific power that maximizes the neutron multiplication for high-burnup fuel with actinides and fission products assumed. The phenomenon will require further study to understand and quantify.

As stated above, operating histories are merely variations in operating power over the life of the fuel (downtime is equivalent to very low-power operation). Each variation results in a different equilibrium concentration for short-lived nuclides; similarly, the length of time at a given power level determines the amount of inventory of longer-lived nuclides that do not have time to come to equilibrium. In both cases, the final nuclide concentrations are most sensitive to late-in-life power variations, but the sensitivity of a nuclide inventory to past exposure history will be directly related to its half-life and removal cross section. Although the integral studies performed to date provide a good basis for recommendations, a study which investigates the behavior of each nuclide of Table 2, together with variations in the assumed limited set of nuclides applied in criticality calculations, would be instructive in determining the form and magnitude of limiting operating history effects. 


\subsubsection{Fixed Burnable Poisons}

Fixed poison rods are commonly used for reactivity control and enhanced fuel utilization in PWRs. Axial power shaping rods (APSRs), burnable poison rods (BPRs) and other forms of poison rods are applied in many PWR designs. The net effect of poison rods is the same as that of soluble boron, since the same mechanism applies: preferential removal of thermal neutrons. However, rod effects are more localized, resulting in localized spectral hardening, non-uniform burnup across the assembly at a given axial height, and atypical axial burnup profiles. In addition, BPRs are effectively depleted in the first third of assembly life. After this time, the effect of the BPRs decreases with additional burnup. Therefore, the impact of the fixed poisons is dependent upon the assembly exposure prior to BPR depletion, the subsequent accumulated burnup, and possibly the poison loading within the rods. Studies to assess the significance of fixed burnable poisons are minimal, but early work 13 which compared a depletion case (4.2 wt \% ${ }^{235} \mathrm{U}, 36 \mathrm{GWd} / \mathrm{MTU}, 5$-year cooled) with 20 BPRs in an assembly to a depletion case with no BPRs found that the change in a storage cask $k_{\text {eff }}$ value was $0.6 \%$ higher for the cask fully loaded with assemblies that had the maximum number of BPRs inserted during the depletion. Indications from this study are that insertion of a maximum BPR loading in all depletion analyses would be a simple, yet not overly conservative approach to facilitate allowance for assemblies with BPR rods.

Because of the routine use of these fixed burnable absorbers in current assembly designs, it is apparent that consideration for their use within a burnup credit evaluation must be investigated. A study is needed to confirm the initial findings cited above and to consider the range of boron loadings as well as the discharge time relative to BPR burnout in various fuel assembly designs. Guidance on the approach needed to provide a bounding set of SNF isotopic data for BPR assemblies should be prepared.

\subsubsection{Integral Burnable Poisons}

In addition to fixed poisons, integral burnable poisons are also used for reactivity control and enhanced fuel utilization. Integral burnable poisons refer to burnable poisons that are an integral part of the fuel within an assembly. These include integral fuel burnable absorber (IFBA) rods, in which the fuel pellets have a boron coating, and $\mathrm{UO}_{2} / \mathrm{Gd}_{2} \mathrm{O}_{3}$ rods. Integral burnable absorbers are common in current PWR fuel designs. Except for very early designs - typically initial core loadings - all BWR designs use burnable poison rods $\left(\mathrm{UO}_{2} / \mathrm{Gd}_{2} \mathrm{O}_{3}\right)$ for reactivity control. In the past control blades were also partially inserted for flux shaping. The net effect of integral burnable absorbers is the same as that of fixed burnable poisons, since the same mechanism applies: spectral hardening due to preferential removal of thermal neutrons. However, the assemblies are designed such that the burnable absorbers are effectively depleted in the first third of the assembly life, and as a result, the assembly reactivity actually increases with burnup to a maximum where the integral absorber is essentially depleted. This peaking of reactivity during irradiation is more complex (see Figure 5) than can be covered by a simple parametric analysis. However, a better understanding of the controlling parameters is needed in order to establish local criteria for such assemblies. Development of a firm understanding of the relationship between integral poisons and depletion methods is ongoing, and few definite conclusions can be drawn at this point. However, Reference 30 does lay the groundwork for future work by comparing one- and two-dimensional depletion methods, and cases with and without integral poisons present.

\subsubsection{Summary of Depletion Modeling Parameters}

Although a wide variety of parameters are included in a SAS2H depletion model, representing in some cases a relatively broad range of operating conditions, most of the parameters discussed above are similar in the fact that reactivity effects are driven by spectral changes induced by variations in each parameter. Increased reactivity is 


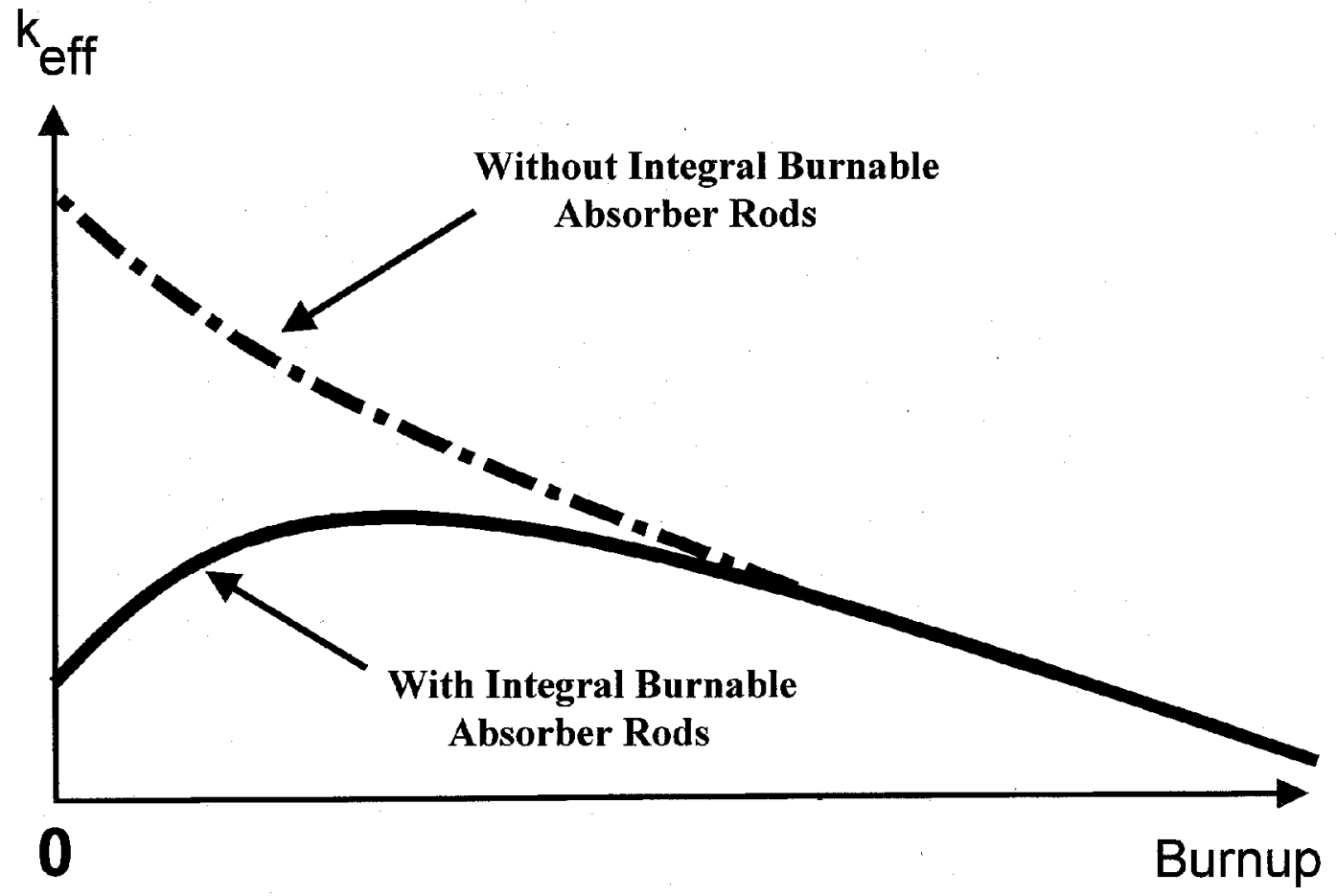

Figure 5 Schematic of $k_{\text {eff }}$ change with burnup for assemblies with and without absorber rods

seen for variations that result in increased spectral hardening. Whether spectral hardening occurs as a result of increased thermal-neutron capture in absorber materials or increased fast-neutron absorption in ${ }^{238} \mathrm{U}$, the net effect is the same: plutonium breeding is enhanced, and less ${ }^{235} \mathrm{U}$ burnup is necessary for fixed power operation. Thus, at end of cycle, fuel burned in a harder spectrum has less effective ${ }^{235} U$ burnup due to more efficient utilization of ${ }^{238} \mathrm{U}$ to breed extra fuel.

Nevertheless, spent fuel burnup is more sensitive to some of these parameters than to others. Table 4 summarizes the discussion in the preceding paragraphs, including specific power and operating history effects. For each parameter, the bounding condition (the state that results in the most conservative estimate of fuel reactivity), the sensitivity range observed in calculation over a typical range (where appropriate), and a recommended modeling approach for the parameter are provided. No specific recommendations for bounding parameters are given. Although expected values are listed in the preceding subsections, these values should be confirmed or revised by a survey of operational data before firm recommendations are made. 
Table 4. Summary of information on depletion modeling parameters

\begin{tabular}{|c|c|c|c|}
\hline Parameter & Bounding condition & $\begin{array}{l}\text { Estimated } \\
\text { sensitivity }\end{array}$ & Recommended value/model \\
\hline $\begin{array}{l}\text { Fuel temperature } \\
\text { Sect.4.2.1 }\end{array}$ & Highest temperature & $4-5 \mathrm{pcm} / \mathrm{K}$ & $\begin{array}{l}\text { Max. pellet-average } \\
\text { temperature }\end{array}$ \\
\hline $\begin{array}{l}\text { Moderator temperature } \\
\text { (PWR) } \\
\text { Sect. 4.2.2) }\end{array}$ & Highest temperature & $35-90 \mathrm{pcm} / \mathrm{K}$ & $\begin{array}{l}\text { Maximum core outlet } \\
\text { temperature }\end{array}$ \\
\hline $\begin{array}{l}\text { Moderator density (BWR) } \\
\text { Sect. 4.2.2) }\end{array}$ & Lowest density & $10^{3} \mathrm{pcm} /\left(\mathrm{g} / \mathrm{cm}^{3}\right)$ & $\begin{array}{l}\text { Minimum channel outlet } \\
\text { density }\end{array}$ \\
\hline $\begin{array}{l}\text { Soluble boron concentration } \\
\text { Sect. 4.2.3 }\end{array}$ & Highest concentration & $3-3.5 \mathrm{pcm} / \mathrm{ppm}$ & $\begin{array}{l}\text { Maximum cycle-averaged } \\
\text { concentration }\end{array}$ \\
\hline $\begin{array}{l}\text { Operating history } \\
\text { (Sect. 4.2.4) }\end{array}$ & $\begin{array}{l}\text { High power late in life } \\
\text { (actinide-only) }\end{array}$ & N/A & $\begin{array}{l}\text { Assume simple operating } \\
\text { history, with margin } \\
\text { of } 200 \mathrm{pcm} \text { or more }\end{array}$ \\
\hline $\begin{array}{l}\text { Specific power } \\
\text { Sect. 4.2.4 }\end{array}$ & $\begin{array}{l}\text { High specific power } \\
\text { (actinide-only) }\end{array}$ & N/A & $\begin{array}{l}\text { High but credible specific } \\
\text { power }\end{array}$ \\
\hline $\begin{array}{l}\text { Fixed/Integral burnable } \\
\text { absorbers } \\
\text { (Sect. 4.2.5, 4.2.6) }\end{array}$ & $\begin{array}{l}\text { Burnable absorbers } \\
\text { present during } \\
\text { depletion }\end{array}$ & N/A & $\begin{array}{l}\text { May not be excessive to } \\
\text { assume fixed burnable } \\
\text { absorbers present, but } \\
\text { further study is warranted. }\end{array}$ \\
\hline
\end{tabular}

\subsection{Cooling Time}

The 5-year cooling time assumed historically in many burnup credit analyses can be traced back to the early policy of the DOE Office of Civilian Radioactive Waste Management not to accept fuel for disposal unless it had a 5-year cooling time (sufficient to reduce radiation sources and decay heat values to levels that facilitate higher-capacity cask designs). Fuel discharged from a reactor increases in reactivity for several days due to the decay of short-lived poisons. After this point, reactivity decreases continuously with time out to about 100 years, at which time it begins to increase. The reactivity continues to increase until a second peak at around 30,000 years, after which time it begins decreasing again 22 The reactivity of the second peak is always less than that occurring at 5 years. This means that an assumed cooling time for 5 years is conservative for any cooling time beyond 5 years. The magnitude of the conservatism depends on the initial enrichment and burnup of the fuel. 21,22 Additional conservatism may be added by basing calculated nuclide compositions on a shorter assumed cooling time period (i.e., cooling periods as short as 1 year).

The effect of cooling time on $k_{\text {eff }}$ for an infinite PWR pin-cell lattice is shown in Figure 6 for various burnup and initial enrichment values. Note that as burnup increases, the effect of cooling time is more pronounced due to the increased quantity of ${ }^{241} \mathrm{Pu}$ and fission products relative to the remaining inventory. Reference 22 provides a comparison of absorption fraction versus burnup and further illustrates this increase in the negative reactivity 


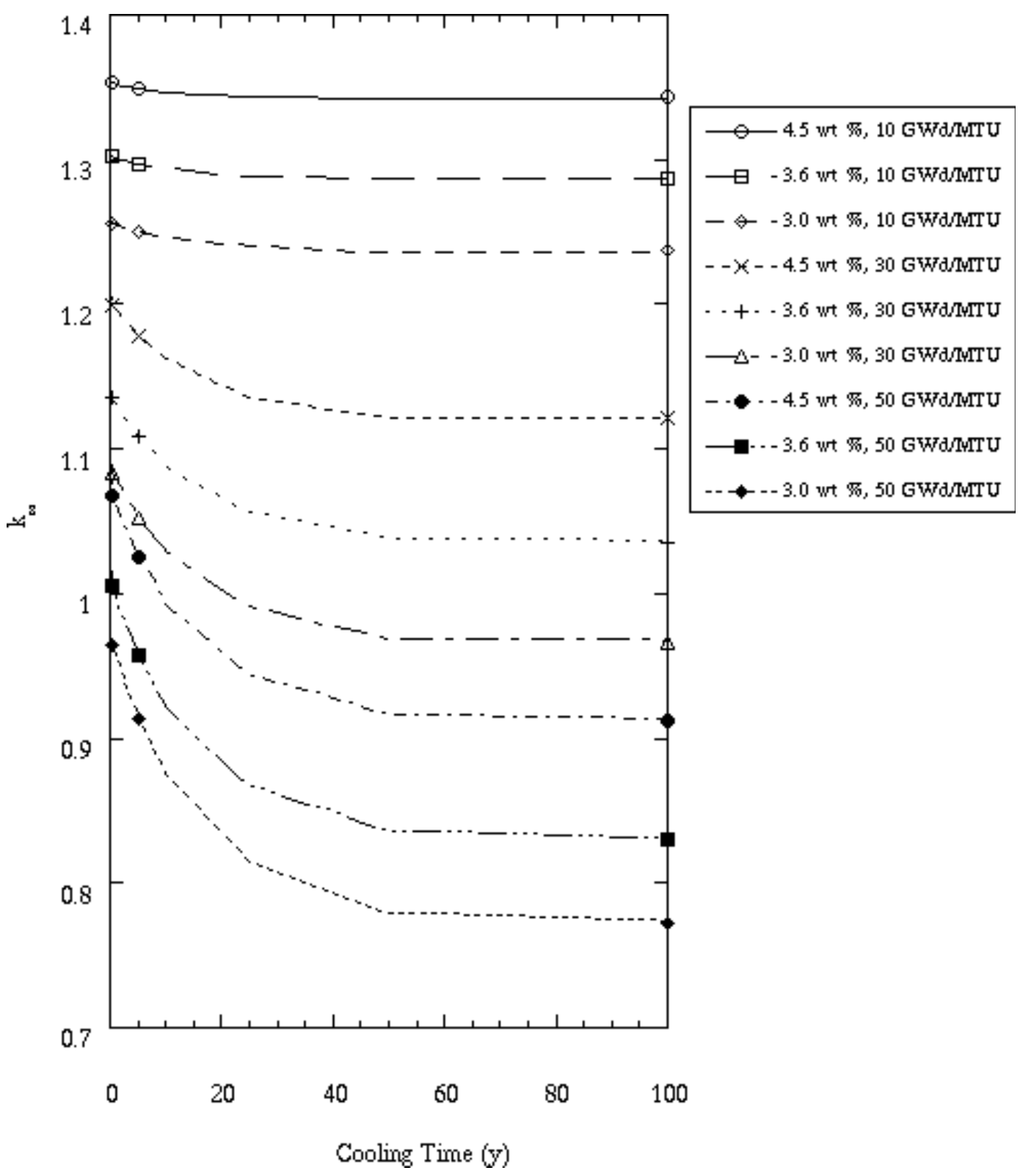

Figure 6 Plot of $k_{\text {eff }}$ versus cooling time for various enrichments and burnup values (from Ref. 21) 
worth from ${ }^{241} \mathrm{Pu}$ decay and fission product absorption. Since the reactivity of low-burnup fuel at the ends of the SNF is rather insensitive to cooling time and the reactivity of higher burned fuel decreases significantly with cooling time, the relative reactivity worth of the ends will increase with cooling time.

From a modeling perspective, it should be recognized that some codes used to predict SNF isotopic information for use in reactor operation do not always provide predictions of all the individual nuclides created during the depletion and decay process. Thus, if sufficient nuclides are not available from the discharge SNF inventory, the inventory of the nuclides predicted by the decay process will not be correct. Consequently most approaches used to date for dry storage or transport cask burnup credit have used point depletion codes which typically include sufficient nuclides to enable a correct decay calculation.

\subsection{Axial Burnup Profiles}

\subsubsection{Phenomena Associated with Axial Effects}

The dynamics of reactor operation result in non-uniform axial-burnup profiles in fuel with any significant burnup. At beginning of life in a PWR, a near-cosine axial flux shape will begin depleting fuel near the axial center of a fuel assembly at a faster rate than at the ends. As the reactor continues to operate, the cosine flux shape will flatten because of the fuel depletion and fission product poisoning that occurs near the center. However, because of the relatively high leakage near the end of the fuel, burnup will drop off rapidly near the ends. Partial length absorbers or non-uniform axial enrichment loadings can further complicate the burnup profile. In a BWR, the same phenomena occur 30 but the burnup profile is further complicated by the significantly varying moderator density profile and by non-uniform axial loadings of burnable poison rods and uranium enrichment.

Under a fresh fuel assumption, it is reasonable to assume that fuel is uniformly distributed along the length of a rod, or has discrete axial variations in the case of non-uniform initial loadings. However, for a spent fuel assembly with a reported level of burnup, the burnup value is typically an estimate of the axially averaged burnup. Although it is possible to calculate nuclide concentrations for the average burnup and assume that the material is uniformly distributed along the length of the fuel rod, this is contrary to the reality of the true burnup profile that exists in a spent fuel assembly.

The fact that there is a difference between the $k_{\text {eff }}$ value calculated assuming an axially varying burnup profile and that calculated assuming a uniform (flat) burnup profile has become known as the "end effect." When assuming an axially uniform distribution of SNF nuclides, the most reactive region of a fuel assembly is at the axial midplane, because leakage increases with distance from the center. However, in reality, the most reactive region of spent fuel is toward the ends, where there is an optimum balance between increased reactivity due to lower burnup and increased leakage due to closer proximity to the fuel ends 2 A fairly extensive review of axial burnup distribution issues that are important to burnup credit criticality safety analyses is presented in Ref. 33 .

Participants in the OECD/NEA BUCWG performed criticality calculations for a 3-D infinite lattice of axially finite PWR pin cells $\frac{14}{14}$ This benchmark endeavored to study the effect of an axial-burnup profile in a multidimensional model. Twenty-two cases were analyzed, with varying enrichments and burnups. A single symmetric burnup profile was applied, broken into nine non-uniform heights. Local burnups for each region were assumed by multiplying a normalized burnup distribution by the assembly-averaged power. Calculations were performed with and without the profile, to assess the magnitude of the end effect. The following items were noted in the results with respect to the end effect: (1) the end effect increases with increasing burnup and cooling time; (2) it is most pronounced when fission products are present; (3) the end effect is negative for low-burnup and short cooling times, 
but becomes positive and of greater magnitude at high-burnup and cooling time; (4) the cross-over from negative to positive occurs around $25 \mathrm{GWd} / \mathrm{MTU}$ when fission products are modeled, and near $30 \mathrm{GWd} / \mathrm{MTU}$ when fission products are not modeled; and (5) the cross-over from negative to positive occurs at slightly higher burnup when fuel enrichment increases.

The OECD/NEA BUCWG also performed a study of axial burnup effects using a conceptual cask configuration. This problem set ${ }^{17}$ employed the same axial models and isotopics as were used in the initial study 14 but only nine higher burnup cases were analyzed, with fuel at an enrichment of $4.5 \mathrm{wt} \%$. The model consisted of a set of 21 assemblies, using axially symmetric spent fuel isotopic specifications but within an axially asymmetric cask. Poison-plates were modeled between fuel assemblies. In general, the same trends noted above for the infinite array model were also noted in the cask model.

Early efforts to address the axial end effect attempted to use the approach of the SFPs where a margin was added to compensate for using a uniform profile ${ }^{34}$ However, this approach was abandoned when further analyses determined the end effect varies with cask design, the nuclides included in the safety analysis, and burnup. Depending on the cask design, burnup, cooling time, and fuel assembly irradiation history, positive end effects can vary up to several percent. ${ }^{35}$

In a BWR, the same phenomena come into play. However, a BWR burnup profile is further complicated by several factors, including: (1) axially and time varying moderator density, (2) axially and radially varying fuel enrichments, (3) axially varying poison rod enrichments, and (4) partial control rod insertion. As discussed earlier, the reactivity of BWR fuel increases with burnup to a maximum or peak reactivity where the integral absorber (Gd) is nearly depleted (see Figure 5). When considering the axial-burnup profile, it becomes apparent that the axial zones will not reach their peak reactivity simultaneously. Rather, the integral absorber will be depleted earlier in the axial zones near the center, and thus, the reactivity will peak at the center while significant integral absorber is still present at the ends. Similar to PWR fuel, the axial burnup distribution results in an increasing positive end

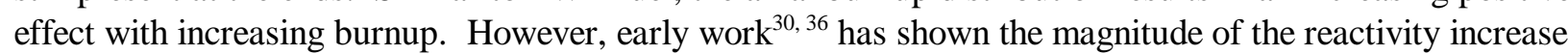
associated with the axial burnup distribution may be larger than that which is typically observed for PWR fuel. Therefore, further effort in this area is necessary.

As indicated by the above discussion, the most reactive region of the fuel is going to be at a location near enough to the ends to take advantage of the lower burnup, but far enough from the ends that leakage is reduced. This point in an assembly is going to be sensitive to local conditions (within a few mean-free paths) and the local reactivity will not be influenced by the shape of the burnup profile outside this limiting region. In this sense, there are any number of axial profiles that would be equally conservative, if the local conditions at the peak reactivity region are held constant. Therefore, rather than performing large sets of criticality analyses using a broad database of axial profiles, it may be instructive to study the axial burnup in terms of the theoretical aspects of competing effects as a means to obtain a better understanding of influence from the profile shape and provide guidance necessary to ensure a conservative profile.

\subsubsection{Profile Database}

The true axial-burnup distribution is not known for the majority of spent fuel assemblies that will be loaded in a cask. In general, only the average burnup is known and documented in plant records associated with each SNF assembly. Thus, to be conservative, one must identify and assume an axial-burnup profile that is realistic but is limiting in terms of the value of $k_{\text {off }}$ associated with the axially varying SNF nuclide compositions. To date, attempts to bound PWR profile 2128,29 have been based on the selection of limiting profiles from a set of calculated 
burnup-dependent profiles obtained from reactor operational data 35,37 No attempt has been made to define a bounding profile for BWR fuel assemblies due to the lack of a similar database of burnup profiles.

A database of 3169 axial-burnup profiles for PWR assemblies has been developed by Yankee Atomic $\stackrel{37}{,}$ representing burnup profiles for spent fuel for a number of different assembly designs and operating histories. These profiles consist of burnups calculated by utilities or vendors for a discrete number (18-24) of axial heights based on core-follow calculations and in-core measurement data. Although the profiles in the database are not measured directly, the use of the same analysis procedures for reactor core-following analyses inspires confidence that the profiles are representative of the actual fuel burnup 38 The database contains data for fuel discharged up to the mid-1990s, from three fuel vendors, for 106 total operating cycles, with a nominal (assembly-averaged) burnup range of approximately 3 to $53 \mathrm{GWd} / \mathrm{MTU}$, and initial enrichments of 1.2 to $4.75 \mathrm{wt} \%{ }^{235} \mathrm{U}$. The profiles have been sorted into burnup ranges of roughly $4 \mathrm{GWd} / \mathrm{MTU}$. For each burnup range, calculations have been performed $^{34}$ to determine the most limiting axial-burnup profile.

Existing databases used to determine a limiting axial-burnup profile, such as that described in Ref. 37, certainly have merit in selecting a conservative profile. However, the referenced databases are limited to older assembly designs for PWR fuel only. If it is desirable to continue to base limiting axial profiles on profiles found to be limiting from a database, then the existing database must be expanded to include a broader variety of fuel designs, especially some of the more recent fuel designs. Furthermore, since control rods and partial-length absorbers can have a significant effect on axial profiles, a decision must be made whether to include or exclude such conditions in a database. Information on the use of control-rod insertion during normal reactor operations would be beneficial to better study and understand the potential impact on the axial profile and/or the SNF nuclide composition. Finally, provisions must be made to allow exclusion of profiles from a database if shapes are suspect due to known abnormal operating conditions or other considerations. A potential alternative to an extensive profile database that encompasses nearly all reactor operating conditions is to use assumed profiles in the safety evaluation and then use axial measurements of the as-loaded assemblies to confirm acceptance within the safety basis (see Sect. 5.3). Such a measurement would also provide a means to detect when assemblies have been exposed to unusual reactor operations (e.g., extended insertion of control rods).

No attempt has been made to define a bounding profile for BWR fuel assemblies due to the lack of a database of burnup profiles. Even though measured axial-burnup distributions for several BWR fuel assemblies for end-ofcycle conditions are available, 9,40 a database similar to that developed for PWR fuel is needed. The fact that BWR fuel assemblies are manufactured with variable enrichments both radially and axially, are exposed to time-varying void distributions, contain fixed burnable poison rods, and are subject to partial control blade insertion during operation means that BWR profiles are likely to have more variation than that observed for PWR fuels. Thus, a large database may be necessary to capture all of the important characteristics. Again, no database exists for BWR profiles, and an industry activity to develop such a database would surely have value in implementation of burnup credit in cask storage and transport.

Even with access to a reliable, comprehensive database of profiles, the process for selecting the appropriate profile for use in the safety analysis may be an issue. Does the conservative profile vary with cask design and/or conditions? Does it vary with cooling time? Answers to these questions require some further study. To date, the limiting profile has been obtained by direct solution of fuel assembly configurations for each axial-burnup profile to be evaluated 34 To accommodate the large number of profiles present in the PWR database ${ }^{37}$ simplifications and approximations in the analytic model were required and the analyses have to be repeated for significant design changes or variations in the model assumptions. Perturbation theory provides an alternative approach for determining the limiting profile from an existing database. The approach involves adjoint analysis that provide importance functions which can be quickly folded with each burnup profile distribution to obtain a figure of merit 
relating the burnup profile to its reactivity worth. Using the adjoint analysis for each cask design and limiting configuration, modifications or additions in the profile database can be quickly assessed. Such a method should be studied for feasibility.

\subsubsection{Axial Modeling Approximations}

In any spent fuel assembly, fuel burnup is a continuous function of axial location. However, in a numerical model, a depletion calculation must be performed for each of a set of finite burnup regions in the model to estimate the contents of the spent fuel at that burnup state. Therefore, in practical application, spent fuel models must apply a set of discrete burnup intervals in which a constant burnup over each interval is assumed. As with any differencing approach, care must be taken to ensure that the spatial discretization is fine enough to capture physical phenomena. Sensitivity studies $21,8,30,33$ have shown that a relatively course axial discretization, typically consisting of 7-11 axial regions, is sufficient to converge on the predicted eigenvalue for a spent fuel system. However, the axial

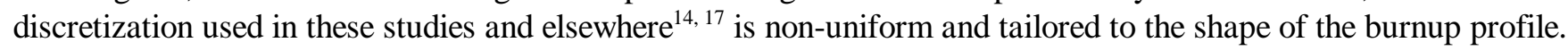
All known spent fuel profiles tend to be fairly uniform over most of the central region, but with significantly decreasing burnup near the axial ends of the active fuel. Thus, discrete models of burnup can use one to three burnup zones to represent the majority of the length of the fuel (central region), but more discrete zones are necessary to capture the more rapid change in burnup with position near the ends of the fuel. It would be valuable to safety analysts if there were criteria for determining the number and length of zones required in the model based on the axial profile being considered. An example of such criteria would be a zone for each $10 \%$ change in burnup. Such criteria need to be developed and tested.

As noted in Sect. 4.4.1, the spent fuel reactivity is a function of both the burnup distribution and axial leakage; thus the boundary conditions (i.e., assembly or cask conditions at the end of the fuel) may play a role in the strategy for determining appropriate axial modeling approximations. Calculations reported to date have been based on simple axial models with a fixed set of boundary conditions. Future work should study the effect of extreme boundary conditions (i.e, highly reflective, high leakage, loss of moderation) and provide recommendations or guidance on the limiting boundary conditions to assume for normal and potential accident conditions.

\subsection{Horizontal Burnup Profiles}

Radial variations in the neutron flux, which are mainly due to leakage at the core periphery, result in a non-uniform horizontal burnup distribution over the radial extent of the reactor core. As the reactor operates, the radial flux shape flattens due to fuel depletion and fission product poisoning near the core center. However, because of the high leakage near the core periphery, burnup drops off rapidly near the periphery. Ultimately, at the end of a cycle, the individual assemblies located near the center of the core will have a relatively uniform horizontal burnup distribution, while the assemblies near the core periphery may have a significant horizontal variation in burnup 41 Thus it is possible for fuel rods on one side of an assembly to have experienced notably less burnup than fuel rods on the opposite side of the same assembly.

To enhance fuel utilization, assemblies are typically relocated within the reactor core between cycle operations. These fuel management practices tend to effectively reduce the horizontal burnup gradient in normal discharged fuel. However, a periphery assembly discharged after a single irradiation cycle may exhibit a significant horizontal burnup gradient 41

A database containing quadrant-wise horizontal burnup gradients for 808 PWR assemblies $(\mathrm{W} 17 \times 17$ and B\&W $15 \times 15$ ) has been prepared, 41 and the database has been examined for trends with the number of operating cycles, 
accumulated burnup, and initial enrichment. No trend with initial enrichment was observed. However, the horizontal gradient was shown to be inversely proportional to accumulated burnup and number of cycles, which are obviously closely related. In other words, the horizontal variation in burnup decreases with increasing burnup. Axial variation of the horizontal burnup distribution has not been addressed.

The horizontal variation in burnup is a criticality safety concern in the event that two or more assemblies are placed in a configuration such that their low-burnup zones are adjacent, thus resulting in an increase in reactivity 11 This reactivity increase will be greatest in small cask designs - such as truck casks - where radial neutron leakage is significant. Although the effect is not expected to be significant in large rail casks and the probability of placing assemblies in such a configuration is small, this concern must be addressed in burnup credit safety analyses.

Based on the horizontal burnup database, Ref. 11 has somewhat arbitrarily assigned very conservative bounding values for horizontal burnup gradients to be used in actinide-only burnup credit applications. Further, these gradients are to be applied in conjunction with the most reactive loading configuration. While the proposed approach will conservatively address the concern related to horizontal burnup distributions, it appears to be excessively conservative. Studies should be performed to quantify the level of conservatism associated with this approach and subsequently assess the value of developing a less-limiting approach. 


\section{TECHNICAL AND LICENSING ISSUES}

The purpose of this section is to identify and discuss the technical and licensing issues associated with facilitating the use of burnup credit in storage and transport casks. A discussion of the status of these issues and areas where additional work may be needed are presented.

\subsection{Validation - How Much Is Needed?}

Requirements for validation of codes and data used for criticality safety outside reactors is provided by ANSI/ANS8.1. This standard requires that the calculational method be validated by comparison with "the results of critical and exponential experiments." Such a comparison yields information on biases and uncertainties in the calculational methods and model. The area of applicability for the calculational method depends on the characteristics of the measured critical experiments that are considered. The standard gives no guidance on how to establish the area of applicability (e.g., which parameters, characteristics, etc. and how similar they should be).

The process of performing criticality calculations for spent fuel in a burnup credit model for transport or dry cask storage requires two distinct sets of calculations - the first to estimate the isotopic contents of spent fuel based on depletion calculations; the second to perform a criticality calculation based on the predicted isotopic contents from the first set of calculations. Thus, application of ANSI/ANS-8.1 to burnup credit validation becomes somewhat complicated by (1) the need to consider the depletion analysis methodology and the criticality analysis methodology and (2) the lack of spent fuel critical experiments.

The nature of experimental data appropriate for use in validation of burnup credit analysis methodologies and the value and applicability of such data have been debated topics for over a decade. Available (albeit some are proprietary) experimental data include chemical assays of SNF inventories, critical experiments performed with fresh fuel in cask-like geometries, reactivity-worth measurements, subcritical experiments, and reactor critical configurations. The following subsections discuss each of these sources of measured information and their potential value to the validation process.

\subsubsection{Chemical Assay Measurements}

Radiochemical assay measurements have been made for select spent fuel nuclides, for both PWR 4 $42-48$ and BWR fuels 40 The majority of these measurements have been used to determine the biases and uncertainties of computational methods ${ }^{24-26}$ In addition, Ref. 50 is a compilation of sources of radiochemical assay data from these and other sources. A very limited amount of assay data for mixed oxide (MOX) spent fuel is available from old U.S. test program $\stackrel{51,52}{5}$ and the more recent ARIANE program coordinated by Belgonucleaire. Reference 53 describes sources for additional isotopic assays and assesses the completeness of available data describing each set of measurements. Appendix A discusses the availability of assay data in other countries.

Chemical assay data have historically focused on the major actinides within PWR spent fuel. The actinides of importance in burnup credit have been measured in 20 or more independent chemical assay evaluations of PWR fuel. For most fission product nuclides important in burnup credit (see Table 2), very few assay measurements have been made. In general, the available PWR spent fuel assays correspond to older fuel designs and are limited to less than $40 \mathrm{GWd} / \mathrm{MTU}$ and $3.5 \mathrm{wt} \%$. Additional PWR and BWR spent fuel assays are currently being performed to support DOE programs, but have not been completed and documented at this time. 
The use of the chemical assays in the validation process involves a comparison of predicted nuclide concentrations to the measured concentrations. The depletion model is based on the known in-core history for the fuel sample that was characterized. Given a significant number of comparisons, it becomes possible to statistically estimate the bias and uncertainty in the ability to predict the concentration of a given nuclide. The bias is obtained by finding the average difference between computed and measured concentrations for each individual nuclide; the uncertainty characterizes in a statistical manner the variation of individual comparisons around the mean. $24-26$ For conservatism, the total uncertainty should also include statistical uncertainty based on a limited sample size. Reference 25 describes an approach for calculating bias and uncertainties such that one has a reasonable confidence that one can conservatively predict the concentration of a nuclide. Conservatism is defined in terms of a concentration that has the effect of maximizing $k_{\text {eff }}$ for a system. A second statistical approach is presented in Ref. 11. In both of these procedures, calculated biases and uncertainties include any biases and uncertainties inherent in the experimental measurements. Thus, there is potential for offsetting errors in the bias, and the uncertainty may not be properly characterized. However, this is a random process, and non-offsetting errors would also be present.

Note that the procedure described above determines the calculational biases and uncertainties for each individual isotope evaluated. Simultaneous application of conservative corrections to individual nuclides within a predicted SNF inventory has potential to be a departure from reality since a correction in one nuclide may be inconsistent, from a physics standpoint, with a correction in a related nuclide. Additionally, given the limited number of chemical assays available, and the range of enrichments and burnups represented by these data, it has not been possible to clearly establish trends in biases and uncertainties as a function of the governing parameters. Although some chemical assay data exist for a moderate range of burnups, other factors also vary (i.e., assembly design, operating history, poison concentrations, etc.). Insufficient data prevent the application of a multivariate evaluation. Although additional measurements should be pursued where essential (high-enrichment and highburnup conditions), the lack of facilities to handle and process spent fuel, combined with the cost of the procedure itself, will limit the number of samples available for validation in the near future. Thus, other options that can provide technical justification for extending the range of the validation and/or interpolating on the range should be considered in conjunction with new experimental data.

The recent NRC guidance 7 provides a method by which burnup credit may be applied for fuel enrichments in the 4-5 wt \% range. However, radiochemical assay data used for the validation of depletion methods are currently limited to enrichments of less than $4 \mathrm{wt} \%$. The offset method recommended in Ref. 6 assesses a penalty for enrichments in the 4-5 wt \% range because there are no measurement data in this range. However, there is no technical basis for this extension; justification is based on experience and engineering judgement. Again, methods that can provide a derived basis for extrapolation of the current limits need to be explored.

\subsubsection{Critical Experiments with Fresh Fuel}

The validation of criticality safety analysis codes using critical experiments with unirradiated fissile material is a procedure that has been applied for years to meet the requirement of ANSI/ANS-8.1. Experiments exist for a wide

variety of conditions representative of pin lattices within cask environments ${ }_{54}$ The value of fresh fuel critical experiments to validation of spent fuel in casks relates to the fact that these experiments provide validation of the particle transport models and cross-section data within cask-like conditions. However, these experiments do not contain the same relative compositions or even all of the nuclides that are present in spent fuel. Thus, there is a need to limit the nuclides to those present in the critical experiments (typically plutonium and uranium isotopes only) and/or demonstrate their applicability to a spent fuel inventory. Proprietary fresh fuel experiments with uranium and plutonium compositions similar to that of typical spent fuel have been performed in France (see 
Appendix A and Ref. 55. Acquisition of such information would be very valuable for use in actinide-only burnup credit approaches and would assist in validation for casks seeking full burnup credit. Also, proprietary fresh fuel experiments with lattices surrounding cans of fission product solutions have been performed in France and would be excellent experiments to use if credit for fission products is sought.

\subsubsection{Reactivity-Worth Experiments}

To bypass the difficulties associated with using spent fuel assemblies in critical experiments, spent fuel samples (pellets) and samples doped with fission products have been inserted within a fresh fuel system to obtain reactivity worths 56 Unless the sample is large enough to provide a significant perturbation to the reference fresh fuel system, the reactivity worth cannot be easily calculated with conventional Monte Carlo codes that are typically used for criticality safety analyses. These experiments can thus provide a means to obtain validation of the reference cross sections used in the criticality analysis, but little else. The French program for burnup credit relies heavily on this approach in conjunction with chemical assay data to demonstrate that the predicted fission product worths are conservative for their codes and that the uncertainty in the fission product cross sections is encompassed by the uncertainty in the prediction of the fission product inventory. Sufficient system perturbation to enable an accurate measure of reactivity worth typically requires isotope concentrations much greater than those present in a spent fuel sample.

The U.S. DOE is currently exploring the potential and the benefits of obtaining the fission product samples from the French and performing reactivity-worth experiments in a critical experiments facility or a research reactor. The French have expressed a willingness to loan the samples, but a final decision on performance of the experiments has not been made. A DOE Nuclear Energy Research Initiative project is also funded to investigate performance of worth experiments in the facilities at Sandia National Laboratories. Current activities are directed at getting safety approvals; ideas on the specific type of worth measurements have not been formulated.

Reactivity-worth measurements using portions of spent fuel assemblies have been proposed in the United State 57 and by Belgonucleaire as part of their REBUS experimental program $\frac{58}{1}$ The purpose of these experiments was to provide some very limited measurements with actual spent nuclear fuel. When doing reactivity-worth measurements with spent fuel samples, the experiment must either have accompanying destructive assays performed or the fuel design and reactor operation needs to be sufficiently characterized such that an integral-type benchmark (isotopic prediction and reactivity worth prediction) can be performed to provide a combined validation of both the depletion and criticality methodology.

\subsubsection{Subcritical Experiments}

The ideal experimental method for assessing the ability of a model to predict the multiplication factor of a system would be to place spent fuel in a cask or cask-like configuration and perform critical experiments. Such experiments are extremely challenging because it is much more difficult to perform because it is extremely difficult to make even low-burnup spent fuel go critical in a controlled manner without first adding some fresh fuel. This is particularly true under cask conditions where external absorbers (basket material) are present. Spent fuel critical experiments are also complicated by the fact that the fuel samples are highly radioactive, and not as easily manipulated as unirradiated fuel. The expense and complexity of a spent fuel critical is further exacerbated by the need to determine the spent fuel composition by chemical assay (very expensive due to the potentially large number of measurements required) or perform predictive analysis validated against other chemical assay information.

At this time, no critical experiment using commercial spent fuel in a cask configuration is known to have been performed, although they have been studied 59 
An alternative to spent fuel critical experiments are subcritical multiplication measurements using spent fuel. Calculations could then be performed to show the capability to match the predicted multiplication factor to the measured value. As with a spent fuel critical experiment, this validation process would require predictions of spent fuel contents prior to the criticality calculations, and would therefore be an integral approach for validation. However, the spectrum should be very similar to that seen in a cask environment and the use of subcritical methods should allow increased flexibility in measuring different configurations. Besides the practical difficulty of handling spent fuel, the performance of subcritical measurements using spent fuel are made difficult by the practical difficulties with such measurements in a strong radiation field and the need to interpret $k_{\text {eff }}$ from the actual measured quantities ${ }_{60}^{60}$ The accuracy of subcritical measurements in providing a $k_{\text {eff }}$ value for validation is not as good as that provided by a critical experiment, but the advantage of having an actual spent fuel measurement and its potential to validate SNF cross sections (actual measured quantities are very sensitive to cross-section errors) means that such an experiment should be explored if additional measured data are deemed necessary.

\subsubsection{Reactor Critical Configurations}

A broad database of critical experiments with partially burned and spent fuel exists in the form of critical configurations within an operating reactor environment. At a commercial reactor startup, a controlled approach to criticality is always taken as part of the startup testing. The conditions at the point of criticality are well defined. Startups at the beginning of a fuel cycle contain a mixture of fresh and burned fuel, and often burnable poisons are present; startups occurring late in a fuel cycle are based on a combination of burned and spent fuel, and burnable poisons have typically been depleted.

Like the spent fuel experiments described earlier, the calculational model of a reactor-critical state will require the prediction of spent fuel inventory for each assembly. Given the size of a commercial reactor combined with the variation in operating conditions during a fuel cycle, the task of estimating spent fuel contents at the time of a startup critical can be rather formidable. However, several reactor-critical models have been developed, and the capability to closely predict criticality under reactor conditions has been demonstrated, 61,62

The advantage of using reactor criticals in some fashion as part of the validation process is that they provide measured critical values for systems actually containing SNF. The worth of the spent fuel with respect to the fresh fuel and the degree to which fission products and boron poison concentrations impact the $k_{\text {eff }}$ value are issues that need to be considered when selecting critical configurations for validation. Because of the presence of fresh or partially burned fuel, together with other physical differences, conditions in a reactor environment are dissimilar to those expected in a spent fuel cask. The effect of these differences must be quantified to determine if a reactor environment is neutronically similar to a cask environment.

\subsubsection{Summary and Discussion}

The purpose of a validation activity is to assess the capability of the codes and data to predict reality. As used in criticality safety, the validation process should be able to demonstrate the bias and the uncertainties associated with the analysis code(s) and data. The uncertainties can arise from uncertainties in the experiments, uncertainties inherent in the code models and data, and uncertainties specific to the user (model approximations, selection of code options, etc.). Currently, approaches used for criticality safety validation often apply statistical techniques to derive "bounding" estimates of the bias and uncertainty based on the differences between critical $\left(k_{e f f}=1.0\right)$ and the computed result, together with the spread in the computed results $\frac{54}{4}$ As demonstrated from the previous subsection, no one set of critical experiments can provide adequate validation for burnup credit applications using this approach alone. Thus, the necessary approach involves utilization of all applicable experimental information in a 
manner that reasonably ensures bounding estimates have been determined for the bias and uncertainty. Research needs to be focused on quantifying the value of each type of experiment and investigating validation approaches that effectively combine analysis correlations with the types of experimental information.

The DOE Topical repor 111 used only fresh fuel critical experiments to validate the analysis of $k_{\text {eff }}$ for spent fuel casks and incorporated the nuclide bias and uncertainty by separate adjustment of the predicted SNF isotopics based on comparison with chemical assay data. The limited database of chemical assays and the difficulty and/or uncertainty inherent in the measurement of many of the individual nuclides (most fission products and minor actinides) pose significant obstacles to this phase of the validation process. Even with additional measurements, relatively few data points will ever be available relative to the variety of fuel designs and operating histories to be considered. Thus, given a database with such a limited sample size, it is difficult to obtain meaningful statistics relating predictions as a function of spent fuel characteristics (enrichment, burnup, fuel design, etc.). The critical experiments proposed in Ref. 11 included all the nuclides of the actinide-only inventory used in the safety assessment, although the concentrations and combinations are not that observed in spent fuel. To overcome the limitations of the fresh fuel critical experiments relative to there material compositions, use of reactor-critical configurations have been proposed 63 and studied 61,62

Integral validation involves the use of depletion methods coupled with criticality calculations to determine $k_{\text {eff }}$ for a measured system containing SNF (e.g., a spent fuel critical or reactor critical configurations). In practice, this procedure would be applied in spent fuel cask calculations. The perceived limitation with integral validation is that the biases and uncertainties for the depletion approach cannot be separated from those associated with the criticality calculation, and only the net biases and uncertainties in the entire procedure are obtained. Integral validation allows for compensating errors in the depletion approach (i.e., underprediction of a given nuclide's concentration coupled with simultaneous overprediction of a different nuclide's inventory). Thus, it is desirable to ensure the uncertainty estimated for individual nuclides is understood and properly considered in the safety analysis.

Arguments can be made that reactor-critical configurations are not appropriate even for integral validation because of differences between reactor conditions and cask conditions. However, other arguments can be made in favor of reactor-critical configurations as integral benchmarks, primarily because the design and material composition of the fuel to be placed in a cask is identical to that present in commercial reactors. Thus the issue with reactor critical configurations is their relevance to cask geometries, whereas the issue with fresh fuel critical experiments is their relevance to the inventory of SNF.

Sensitivity/uncertainty (S/U) method $64-65$ have the potential to be of significant benefit in addressing many of the validation issues presented above. Such methods can address the applicability of the fresh fuel critical experiments and reactor critical configurations to cask designs with SNF. Besides defining the applicability of these classes of experiments, S/U analysis can potentially identify deficiencies in the current database and provide a quantitative basis for extension beyond the existing database. The $\mathrm{S} / \mathrm{U}$ methods also have the potential to assess the benefit of reactivity-worth experiments and subcritical experiments and identify potential reductions in the margin of subcriticality allowed by their use. Reactivity-worth experiments and subcritical experiments are prime candidates to support additional validation of fission product cross sections, which have typically not had the scrutiny or intense evaluation dedicated to the primary actinides.

Sensitivity/uncertainty methods may also be an approach that can be used to support expansion of the area of applicability for the chemical assays beyond their current limits in terms of burnup and initial enrichment. In other words, does $3.6 \mathrm{wt} \%$ fuel burned to $40 \mathrm{GWd} / \mathrm{MTU}$ have similar irradiation characteristics as $4.5 \mathrm{wt} \%$ fuel burned to $55 \mathrm{GWd} / \mathrm{MTU}$ ? If sensitivity methods can be used to quantify the similarity between different SNF characteristics, then S/U methods may be able to establish and justify trends such that interpolation and/or 
extrapolation techniques can be used to estimate the bias and uncertainty associated with SNF for which there is no chemical assay data.

Another approach that could be used to obtain uncertainties in the SNF inventory without adjusting each individual nuclide would be to assess the integral effect on $k_{e f f}$ of random variations to the SNF nuclide set within the characterized uncertainty bounds defined for each nuclide. This random variation of the inventory would provide a more realistic distribution of $k_{\text {eff }}$ values for the application that can be directly tied to nuclide uncertainties and prevent simultaneous conservative correction of each nuclide - which is a bounding, but unrealistic approach. A conservative margin can be assigned based on the expected statistical distribution of $k_{\text {eff }}$ values. Perceived advantages (better estimates of the impact of the uncertainty in the spent fuel inventory) and disadvantages (increased complexity and computational time) of this approach need to be studied.

\subsection{Modeling Considerations}

\subsubsection{Depletion Models}

Much of the depletion analyses performed to date for burnup credit evaluations and validation exercises have utilized some version of the SAS2H sequence 60 of SCALE. This analysis sequence solves the neutron transport equation on a one-dimensional (1-D) approximate model of a nonhomogenous assembly lattice, coupled with a point-depletion approach (ORIGEN-S) based on the assembly-averaged fuel flux. Previous work has demonstrated that the ORIGEN2 code could not provide the needed accuracy in the actinide inventory over the range of burnup and fuel designs, while some reactor physics codes did not track sufficient nuclides to provide accurate inventories after significant decay times. Although the SAS2H approach has some shortcomings, it has been shown to do remarkably well for PWR fuel, $16,24,25$ and reasonably well for more heterogeneous (e.g., enrichment and absorber

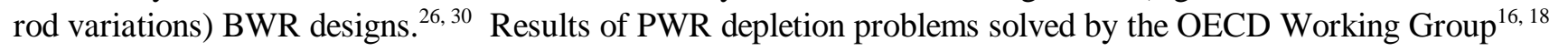
indicate good agreement between SAS2H and a variety of codes, including those that use 2-D geometries in the assembly design. However, for BWR fuel designs, initial comparison of SAS2H with 2-D codes 3067 indicate differences that need to be further investigated and understood to determine the impact of the geometry modeling on the discrepancies.

In particular, the presence of integral burnable poison rods (IBPRs) common in BWR designs complicate the depletion solution of BWR assemblies when using a 1-D approach. The strong absorption near the rods coupled with self-shielding effects in the IBPRs themselves cannot be accurately modeled in SAS2H. This situation should be studied as a part of the study of heterogeneous modeling effects, but methods to allow better treatment of IBPR depletion in a 1-D model should also be considered.

Within the OECD Working Group $\frac{16}{16}$ depletion calculations were performed for three burnups for a pin-cell based on a pin from a CE $14 \times 14$ PWR. Comparisons were made on a nuclide by nuclide basis for each burnup case. Agreement among participant's data indicated potential problems between data libraries or methods employed for ${ }^{238} \mathrm{Pu},{ }^{243} \mathrm{Am},{ }^{109} \mathrm{Ag},{ }^{149} \mathrm{Sm},{ }^{151} \mathrm{Sm},{ }^{155} \mathrm{Gd},{ }^{237} \mathrm{~Np}$, and ${ }^{135} \mathrm{Cs}$. Plutonium and americium discrepancies were believed to be due to incomplete data in libraries used by certain participants. The nuclides ${ }^{149} \mathrm{Sm},{ }^{151} \mathrm{Sm}$, and ${ }^{155} \mathrm{Gd}$ showed the most significant variations among participants. Fission yields, cross-section and parent-nuclide cross-sections are likely culprits and these data should be reviewed to better understand potential uncertainties arising from these data. 


\subsubsection{Calculation of $\boldsymbol{k}_{\text {eff }}$}

The expectations regarding the codes to be used to determine $k_{\text {eff }}$ of a dry storage or transport cask are documented in Refs.1, 2, 68. Monte Carlo codes capable of 3-D solutions of the neutron transport equation are typically required for such applications. With the use of a large distributed fission source inherent with use of an axial burnup profile, concerns have been raised that the codes may not be used in a manner that assures proper convergence of the result to the correct $k_{\text {eff }}$ value. Problems performed by the OECD Working Group have demonstrated that results can vary based on users selection of input parameters crucial to proper convergence. However, Ref. 21 has demonstrated that sampling of the fission source uniformly over the fuel region coupled with adequate parameter specification (1000 particles per generation, $1000-2000$ generations per run) will provide properly converged results for the $k_{\text {eff }}$ value of a SNF cask. To alleviate concerns with user selection of such parameters and/or questions regarding the work of Ref. 21, it is possible to develop an automated scheme within the SCALE/KENO V.a environment that will ensure proper convergence for a spent fuel system. This capability would reduce the potential for user error and provide for more efficient Monte Carlo solutions.

\subsection{Confirmation Measurements for Cask Loading}

Loading of SFPs requires administrative determination of the burnup via the reactor record for the particular fuel assembly. This practice is consistent with ANSI/ANS-8.17 which requires "analysis and verification of the exposure history of each fuel unit" or "a reactivity measurement." However, Regulatory Guide 3.71 adopts ANSI/ANS-8.17 with the exception that loading of a cask licensed for burnup credit should require some physical measurement to verify that the fuel has a burnup matching that predicted by reactor records. This requirement is consistent with ISG8 Rev. 1,7 the IAEA transport regulations, ${ }^{8}$ and current practice in France $\frac{55}{5}$

The DOE, EPRI, and industry have collaborated to propose, develop, and test several measurement techniques that can be used to meet the NRC recommendations of ISG8 Rev. 1. Industry would like to move away from preshipment measurements of each assembly and do measurements within the SFP to obtain a statistical sampling that demonstrates the accuracy of the utilities administrative records relative to fuel exposure history. This can be a significant economic benefit to the industry but its implementation must be done such as not to compromise assurance of the characteristics of the fuel assemblies being loaded in a particular cask. The measurement methods and the various proposed methods for their implementation need to be further reviewed to support development of improved guidance (beyond ISG8 Rev. 1) on regulatory expectations for pre-shipment measurement implementation. Such regulatory expectations would include specification of proper measurement criteria needed to ensure verification of reactor records. An industry report that discusses the variation in the way that utilities obtain and maintain their records on spent fuel burnup together with a discussion of the anticipated uncertainty in the reported burnup would be beneficial to development of loading curves that are independent of the reactor facility.

Some form of axial profile (limiting or otherwise) will be assumed for use in a cask license approval. However, it may be beneficial to verify at fuel loading time that the burnup profile of an assembly is bounded by the assumed profile used in safety analyses. Measurement methods that consist of several axial measurements could be amenable to real-time evaluation of acceptability of the burnup profile if coupled with an adjoint analysis of a selected licensing profile at the time of measurement. The folding of the adjoint information with the measured profile would be evaluated against criteria developed in the licensing approval as a means to ensure that the measured profile is adequate for the particular cask. This method constitutes a conceptual approach at this time and has not yet been developed or tested for feasibility. However, given the wide variety of axial-burnup profiles in the spent fuel inventory, it may be advantageous to further explore this approach. 
Subcritical measurements that provide a GO/NO GO assessment of proper loading (i.e., ensures $k_{\text {eff }}$ remains below a specified limit) is also a concept that could be explored as an alternative to burnup measurements of each assembly. This concept needs extensive development prior to practical implementation but when fully mature may provide distinct advantages relative to loading confirmation and ease of implementation.

In light of the limited attention given to horizontal burnup gradients and the conservative approach that has been conceived in Ref. 11, it may also be beneficial to study how pre-shipment measurements could be used to ascertain the use of an assumed horizontal burnup gradient.

\subsection{Implementation Issues}

Credit for fuel burnup introduces challenges for the industry and the NRC in terms of additional complications in the preparation and review of safety analysis reports (SARs). In addition, there is a need to establish technical specifications to ensure that loaded contents are consistent with the allowable contents analyzed in the SARs. A number of technical issues with regard to burnup credit criticality assessments are not fully resolved, and thus, variations in submitted safety assessments, which will prolong the associated review time, should be expected. Additionally, technical specifications and operating procedures associated with cask loading are more complicated. The SAR for a burnup credit cask must assure that the methods imposed for certifying the cask contents can be readily understood and implemented at any potential facility that has a license to handle SNF. Similarly, the NRC must determine the language and criteria that needs to be included in the certificate of compliance that is issued.

Because the inclusion of burnup credit in the criticality safety assessment for casks is a new addition to industry and NRC procedures, diligence will be required in both the preparation and review process. Ready access to the technical information of import to burnup credit and computational tools that expedite the analyses should facilitate preparation and review of SARs. A goal of current research should be to develop sound technical guidance and criteria to be considered in preparation and review of the SARs and to ensure that adequate computational tools and data are readily available.

Implementation of burnup credit also creates potential concern relative to different off-normal or accident configurations that may need to be considered in the safety analysis. Should a mis-loading event be considered? And if so, what type of mis-loading event? Can a mis-loading event be analyzed in place of the requirement to perform a pre-shipment measurement? Another concern expressed at the OECD Working Group has been the fact that the reduction in conservatism caused by using spent fuel isotopics should cause the reviewer to consider the impact of improbable, but possible cask configurations that could increase the $k_{\text {eff }}$ value. In particular, the concern over SNF assemblies shifting during an accident such that a portion $(5-15 \mathrm{~cm})$ of the ends of the fuel are not separated by the basket poison plates. In a spent fuel cask certified with fresh fuel isotopics, the improbability of the event coupled with the margin of conservatism by using all fresh fuel would seem to negate the need to make such an evaluation. However, in a cask licensed with burnup credit, the margin of conservatism is less and the ends are an important contributor to the reactivity of the cask. Of course a simple fix to this problem would be that cask designers and reviewers ensure the basket poison actually will separate the entire length of the fuel region in all conceivable accident configurations. Except for cask designs that are already licensed, this concern should be readily addressed by careful attention to the basket design. 


\section{PROPOSED RESEARCH AND PRIORITIZATION}

The previous sections identified the parameters, phenomena, and issues important to effective implementation of burnup credit. Recommendations for further work were noted with each topic. This section seeks to establish a priority of the recommended research (in terms of high, medium, or low categories) and provide a concise description of the tasks in order of their prioritization. Although the prioritization of recommended work is somewhat subjective, the following criteria were considered in assigning prioritization: (1) need for technical closure within ISG8; (2) increase in range and type of fuel that can be considered; (3) industry and regulatory needs for safe, simple and cost-effective implementation; (4) increased reactivity credit made available; and (5) anticipated work required for resolution/implementation.

\subsection{High-Priority Research}

It is anticipated that the issuance of ISG8 (see Ref. 7) will prompt license amendment requests that seek credit for fuel burnup. Therefore, the highest-priority research should focus on providing technical closure on unresolved issues within the framework of the ISG8 recommendations and increasing the population of SNF assemblies that can be considered in a cask designed for burnup credit. Closure on these unresolved issues should be done in a manner that enables expansion beyond the framework of the ISG8 recommendations.

Unresolved technical issues that exist within the framework of ISG8 include:

1. parameter specification for depletion analysis (see Sects. 4.2.1-4.2.4,

2. process for selection and modeling of axial and horizontal burnup distributions (see Sections 4.4-4.5),

3. development of guidance for estimating the fission product margin,

4. clarification of validation needs,

5. extension of ISG8 to include assemblies with fixed and integral absorbers, and

6. extension of ISG8 to allow cooling times other than 5 years.

As discussed in Sect. 4.2, the behavior of the parameters important to the PWR depletion analysis are fairly well characterized, but no reference report is available from which to select bounding values applicable to all PWR facilities. An alternative, but seemingly impractical approach, would be to develop a process by which, prior to fuel loading, reactor records are used to ensure the fuel was not exposed to operating conditions outside of those used in the cask licensing process. It is suggested that industry prepare a reference report that provides realistic bounds for the parameters cited in Sect. 4.2 (average soluble boron, outlet moderator temperature, maximum pellet-averaged fuel temperature, and specific power range) based on the performance of existing PWR reactors in the United States.

One process for the selection of axial and horizontal burnup distributions within the framework of the ISG8 is available within Ref. 11. However, the axial burnup database that is available 37 does not encompass all fuel designs and may need to be expanded to cover additional fuel design types and operating conditions. An increased understanding of the phenomena and modeling techniques for both axial and horizontal profiles would be beneficial to better understanding the importance of expanding the profile database and/or providing alternatives to the development and use of a database. The NRC research program currently plans such an investigation as a means to provide increased understanding of the issues and to support a search for potential alternatives to the use of a profile database that would need to continually expand to include ever-changing fuel designs and operating histories. However, as the research program proceeds, it is suggested that the industry pursue efforts to expand the existing database to provide profiles based on new fuel designs and enrichment/burnup regimes (high-enrichment, high-burnup fuel) that may be needed in the near future. In addition, input from industry on the use of control rods 
during normal operations and the impact their use has on the axial-burnup profile and SNF nuclide inventory would be of benefit in considering whether or how to consider the effect of control rods in a burnup credit safety analysis.

The ISG8 requests the licensee to estimate the fission product margin available within the cask. The NRC research program is currently working to provide specific recommendations on how the estimates (e.g., computational benchmarks and/or comparison with available fission product chemical assays) should be developed. This procedure will likely entail development of computational benchmarks against which comparisons can be made.

The short-term need for clarification relative to validation involves the confirmation that use of only fresh fuel critical configurations is adequate to validate actinide-only burnup credit. The NRC research program will use the sensitivity/uncertainty methods of Refs. 64-65 to help identify the adequacy of this approach and, as needed, identify other types of experiments that should be considered in the validation of actinide-only burnup credit. The applicability of using reactor critical configurations to validate actinide-only burnup credit analyses will also be studied using the sensitivity/uncertainty methods of Refs. 64-65. This work would clarify issues relative to perceived needs for additional critical experiments for use in the validation of actinide-only analyses.

A review of recent PWR fuel designs reveals extensive use of fixed and integral burnable absorbers (see Sects. 4.2.5-4.2.6. Increasing the range of PWR fuel designs beyond that allowed by ISG8 is a top priority necessary to allow effective implementation of burnup credit to meet industry needs for a larger portion of the existing SNF inventory. Thus, work to expand the ISG8 to include consideration of these fuel designs is being expedited under the NRC research program and initial results should be provided by early May 2000 .

Although many factors are involved (e.g., fuel design, burnup and initial enrichment, and axial profile), provision to allow cooling times other than 5 years is a desired flexibility voiced by industry. For cooling times greater than 5 years, this flexibility can provide approximately $1 \% \Delta k$ credit per additional 5 years of cooling time (up to $\sim 20 \mathrm{y}$ ). The advantage provided by using longer cooling times in the safety analysis increases with burnup (see Sect. 4.3) and is larger when fission products are included in the SNF nuclide set. Issues that would need consideration in order to allow cooling times other than 5 years are: (1) confirmation that the bounding profile is independent of cooling time and/or selection of bounding axial profile as a function of cooling time, (2) assessment of the uncertainty due to uncertainty in decay data, fission yields, etc., and (3) preparation of an administrative procedure that ensures cooling time is confirmed at cask loading and that the proper loading curve is selected. Provision for cooling times less than 5 years may benefit efforts to optimize cask capacities by mixing of fuel having high thermal and radiation sources with fuel having low thermal and radiation sources. The NRC research program is working to provide input to this issue by early April 2000.

Commensurate with the high-priority work noted above, the technical basis for the ISG8 and a Standard Review Plan (SRP) for use in review of burnup credit cask applications needs to be developed. These documents should provide licensees and NRC staff with technical information and criteria needed to make informed decisions during preparation and review of the safety analysis. A review of pre-shipment measurement techniques that can confirm proper fuel loadings should be included, together with a review and consideration of new accident configurations specific to burnup credit.

The added complexity of linking depletion analyses with a multi-axial-zone cask model will also mean that existing software used in staff review of cask license submittals will need to be upgraded to facilitate the review process. Such upgrades are underway within the NRC research program.

The NRC research program is currently focused on the high priority work areas noted in this section with the goal to complete studies by early FY 2001 (unless other dates are provided above). The goal is to help provide technical 
information that will aid the NRC staff in issuing additional guidance and/or developing a SRP for use of burnup credit.

\subsection{Medium-Priority Research}

With the exception of the cooling time issue noted in Sect. 6.1, research to expand the amount of credit allowed for PWR SNF has been classified as medium-priority research. Besides the consideration of resource allocation, this recommendation is based on the fact that use of burnup credit is a new endeavor within the licensing process and, in the absence of extensive experimental data, it does not seem that additional credit is warranted without some experience with the use of the technology and process. Reference 69 provides a comparison of the French approach to burnup credit (where extensive experience exists) and the recent methods of ISG8. For the assemblies allowed by ISG8, Rev. 1, the amount of burnup credit provided by the two approaches is very similar. Thus, in this document, high-priority research seeks primarily to extend the range of fuel assemblies allowed within the approach of ISG8, while medium-priority research seeks to extend the amount of burnup credit that is allowed.

Increased burnup credit can be obtained by:

1. reducing or eliminating the loading offset specified in ISG8 for fuel with initial enrichments over $4.0 \mathrm{wt} \%$,

2. increasing the allowed burnup for the licensing basis to greater than the $40 \mathrm{GWd} / \mathrm{MTU}$ allowed by ISG8,

3. allowance of credit for fission products, and

4. reducing conservatism in the DOE-proposed horizontal distribution.

Initial enrichments for PWR fuel designs have exceeded $4.0 \mathrm{wt} \%{ }^{235} \mathrm{U}$ for a number of years, and initial enrichments in the range of 4.5 to $4.8 \mathrm{wt} \%{ }^{235} \mathrm{U}$ are currently being used. Initial enrichments are approaching $5.0 \mathrm{wt} \%{ }^{235} \mathrm{U}$. The loading offset was included in the ISG8 because the chemical isotopic assay data to support validation is extremely limited for enrichments greater than $4.0 \mathrm{wt} \%{ }^{235} \mathrm{U}$. Similarly, the burnup allowed for the licensing basis was limited to $40 \mathrm{GWd} / \mathrm{MTU}$ because of the paucity of chemical assay data. Thus, for assemblies with burnup values greater than $40 \mathrm{GWd} / \mathrm{MTU}$, burnup credit is only allowed (by ISG8) for $40 \mathrm{GWd} / \mathrm{MTU}$. Work is needed to provide a process and justification to increase the allowed burnup and initial enrichment based on the limited amount of chemical assay data that are available. Sensitivity and uncertainty methods provide one potential approach to provide a justification, but other approaches should be considered. However, the availability of measured assay data should facilitate any technical justification; thus additional measured data (chemical assay or related integral data) in this regime should be sought and analyzed. A technical justification for an increase in initial enrichment and burnup in the absence of chemical assay data will not be a simple or straightforward task. Thus, efforts to obtain additional assay data need to continue even as approaches such as the sensitivity and uncertainty methods are explored. The NRC research program is making efforts to work with industry, DOE, and other countries to obtain sufficient quantities of measured data such that the sensitivity/uncertainty methods can be tested and a process for improved estimation of the bias and uncertainty associated with prediction of SNF inventories can be developed for use in regimes where chemical assay data are limited or non-existent. This research will benefit other technical areas (i.e., radiation and decay heat sources) related to high-burnup SNF, and a report on the research efforts will be available by the middle of FY 2001.

Similarly, extension of the current ISG8 to allow the fission product nuclides of Table 2 in a burnup credit safety assessment will not be simple or straightforward. Initial analyses at ORNL with a generic rail cask confirm the need for eliminating the offset penalty and including the fission products in order to enable maximum fuel loadings (based on weight and size constraints) with PWR fuel enriched to $5.0 \mathrm{wt} \%{ }^{235} \mathrm{U}$. The validation process will need 
to consider measured systems containing fission products: reactor-critical configurations, reactivity-worth experiments, and additional chemical assay data. The applicability of reactor-critical configurations needs to be confirmed with sensitivity/uncertainty approaches and the process for utilizing the information from the worth experiments needs to be determined. The enhanced sensitivity of subcritical experiments to cross sections indicates they may provide a means to facilitate validation of fission product cross sections. An assessment of the uncertainty in the fission product cross sections within the evaluated nuclear data files would also be of value to ascertain the amount of burnup credit from fission products that should be allowed. Estimates of the reactivity credit available from all the stable SNF nuclides will help indicate the availability of subcritical margin beyond the fission product nuclides of Table 2 and may be beneficial in assessing the extension of ISG8 to include fission products. The NRC research program is now working to formulate ideas and objectives relative to investigating the potential for crediting fission products in the criticality safety analysis. Work will commence once the high priority work areas are completed

As indicated in Sect. 4.5, the approach to account for horizontal burnup distributions seems rather conservative and work to reduce that conservatism may provide benefits to increasing the allowed burnup credit. The NRC research program's efforts to investigate the horizontal burnup profile issue could benefit from additional industry input on the variation of these profiles as a function of axial position. An exhaustive database is not needed, merely sufficient representative information to help judge whether the existing proposed approach of Ref. 11 is overly conservative for typical PWR operations. The NRC research program will initiate studies in this area in early FY 2001.

\subsection{Low-Priority Research}

Low priority research is classified into three sub-categories: (1) research beneficial to improve the efficiency of the licensing process and/or operational implementation of burnup credit for PWR SNF, (2) research needed to extend burnup credit to BWR fuel designs, and (3) research needed to extend burnup credit to PWR and BWR fuel designs containing MOX. Research in the first sub-category would include efforts to improve the process by which the cask contents are certified and to investigate the use of pre-shipment measurements that would enable use of more realistic axial- and horizontal-burnup profiles. The second and third sub-categories are very broad and encompass investigations on the parameter, phenomena, and issues discussed in Sects. 4-5 as they apply to BWR and MOX fuel designs.

For both BWR and MOX fuel designs, research is needed to demonstrate the relevance of critical experiments and reactor-critical configurations to the validation process. The void fraction in a BWR makes the applicability of critical configurations to cask conditions less apparent than for a PWR. Also, there is a scarcity of chemical assay data for all ranges of burnup and initial fissile loading for both BWR and MOX fuel designs. Efforts to obtain additional assay data and utilization of the approach identified for extending applicability of PWR assay data need to be initiated. Axial-profile databases are also nonexistent for these two fuel design types, and reference values for the parameters used in the depletion analyses need to be developed. The strong heterogeneity of these designs also needs to be considered in guidance on appropriate models that should be used. Finally, the adequacy of the preshipment measurements developed for use with PWR fuel needs to be established.

The paucity of measured data and the limited experience with BWR and MOX issues related to burnup credit make it likely that the initial guidance for the implementation of burnup credit for these fuel designs will be limited, even after completion of the research work. It is too early to define the nature of future work that might be needed to improve implementation of burnup credit with BWR or MOX fuel designs; however, limited burnup credit may be sufficient for addressing industry needs relative to these fuel types. 
It is possible that either of these three categories of low-priority issues could be elevated to a higher priority as more is learned about the benefits that can be obtained from using burnup credit with these designs. An initial step in a BWR-related research program would be to assess the importance of burnup credit for BWR fuel. Current basket designs (without water gaps) are capable of accepting BWR fuel with average initial enrichments up to $\sim 4.2$ wt $\%$, without credit for burnable absorbers. BWR fuel designs have only recently exceeded $4.2 \mathrm{wt} \%$ enrichment, with very recent designs featuring average initial enrichments as high as $\sim 4.5 \mathrm{wt} \%$. Therefore, nonburnup credit BWR fuel baskets are capable of accepting the majority of BWR fuel currently in storage. Consequently, burnup credit for BWR fuel may not be needed in the near future (especially if a minimum 5-year cooling time requirement is maintained). Benefits of burnup credit for BWR fuel include: (1) reduction in required basket fixed neutron poison loading, and (2) increase of allowable initial enrichments. Benefits do not include increased canister capacity as they do for PWR fuel.

In conjunction with both of these sub-categories of low-priority research, efforts should be made to identify and obtain experimental information that will help facilitate improved utilization of burnup credit. Additional experimental data are needed to support reduction of conservative margins developed to ensure criticality safety. In the absence of direct validation or understanding of the phenomena, excessively conservative margins may need to be used. Thus, opportunities to obtain experimental data in the domestic and international arenas need to be considered as they arise. Beyond the potential to reduce conservative subcritical margins, additional experimental data should help reduce uncertainty in the licensing process and help reduce the time involved in preparing and reviewing the criticality safety assessment. A basis by which to evaluate the value of an experiment to reducing the margin of subcriticality is possible with the sensitivity/uncertainty methods described in Refs. 64-65. However, even without such a basis, additional experimental data in a relatively new field, such as burnup credit, should enable the community to gain improved understanding and added confidence in the codes and data proposed for use.

Advances in subcritical measurement techniques should be closely monitored. The capability to perform such measurements will provide extremely valuable benchmarks for the verification of integral calculations of depletion and criticality calculations under spent fuel cask conditions. In the absence of spent fuel critical experiments, subcritical measurements may be one of the few avenues available to validate burnup credit methods that include fission product credit. In addition, subcritical measurements may offer an alternative to assembly burnup verification measurements.

A large number of experiments are being proposed, or are ongoing, in which fission product samples will/are being measured to determine the worth of the quantified sample. Such measurements complement integral experiments (reactor critical configurations or subcritical experiments) considered to validate fission product credit. Participation in international programs should be encouraged, together with analysis of data to help validate crosssection data for those nuclides.

Continuing analysis of spent fuel samples should be encouraged to extend the range of assay data to higher enrichments and burnups, and to be more representative of the full inventory of commercial spent fuel. Efforts should be initiated to extend the number of measurements for burnup credit nuclides, especially the fission products for which very few measurements exist.

\subsection{Summary}

Table 5 provides a summary of the research objectives, together with their proposed priority categories and the parameters, phenomena, and/or issues they address. In addition, the table contains an indication of the other 
organizations or countries that may be willing to cooperate in the research and/or who have data or information that would be of value to completing the research.

The proposed research efforts are of interest to several organizations - domestic and international. As discussed in Sect. 3 and Appendix A, France has established four joint industry/government working groups to achieve the objectives of much of the research listed in Table 5. The experimental data (critical experiments, reactivity-worth experiments, and chemical assays) from France and Japan (chemical assays) may be of significant value to achieving the research objectives. Similarly active participation in the OECD Working Group on Burnup Credit and the IAEA efforts to monitor burnup credit implementation in various countries can provide valuable information and insights relative to many of the technical issues discussed in this report. 
Table 5 Summary of proposed research objectives and activities

\begin{tabular}{|c|c|c|c|}
\hline Priority & Research objective & Activities/tasks & $\begin{array}{l}\text { Cooperative } \\
\text { participants }^{a}\end{array}$ \\
\hline High & $\begin{array}{l}\text { Consensus parameters } \\
\text { for PWR depletion } \\
\text { analysis }\end{array}$ & $\begin{array}{l}\text { (1) Reference report for PWR operations providing } T_{f}, T_{\text {mod }} \text {, } \\
\text { ppm soluble boron, and specific power range } \\
\text { (2) Study to understand effects of exposure history }\end{array}$ & EPRI, NEI \\
\hline High & $\begin{array}{l}\text { Guidance on selection } \\
\text { and modeling of axial } \\
\text { and horizontal burnup } \\
\text { distribution for PWRs }\end{array}$ & $\begin{array}{l}\text { (1) Study competing effects of profile shape } \\
\text { (2) Update PWR profile database to include current fuel designs } \\
\text { (3) Develop guidance on process to select bounding profile } \\
\text { (4) Develop guidance on axial model (discretization and boundary } \\
\text { conditions) and proper source convergence } \\
\text { (5) Modeling guidance for horizontal burnup distribution }\end{array}$ & $\begin{array}{l}\text { EPRI, NEI, } \\
\text { OECD, DOE, } \\
\text { Utilities }\end{array}$ \\
\hline High & $\begin{array}{l}\text { Benchmarks for } \\
\text { calibrating estimate of } \\
\text { fission product margin } \\
\text { per ISG8 }\end{array}$ & $\begin{array}{l}\text { (1) Develop generic rail and truck cask model and standard } \\
\text { depletion cases } \\
\text { (2) Prepare and document computational benchmark set }\end{array}$ & OECD \\
\hline High & $\begin{array}{l}\text { Confirm applicability of } \\
\text { critical experiments } \\
\text { for PWR actinide-only }\end{array}$ & $\begin{array}{l}\text { (1) Use sensitivity/uncertainty analysis to evaluate applicability } \\
\text { of available critical experiments (fresh fuel and reactor critical } \\
\text { configurations) to estimate subcritical margin for actinide- } \\
\text { only }\end{array}$ & None \\
\hline High & $\begin{array}{l}\text { Extend ISG8 to allow } \\
\text { PWR assemblies with } \\
\text { fixed and integral } \\
\text { absorber rods }\end{array}$ & $\begin{array}{l}\text { (1) Assess impact on } k_{\text {eff }} \text { due to incorporation of absorber rods as } \\
\text { function of absorber loadings and exposure after burnout } \\
\text { (2) Assess modeling issues using multidimensional methods } \\
\text { (3) Identity and analyze any additional chemical assays from PWR } \\
\text { assemblies with absorber rods } \\
\text { (4) Investigate impact of absorber rods on SNF inventory uncertainty } \\
\text { (5) Develop guidance for extension of ISG8 and proper modeling } \\
\text { assumptions }\end{array}$ & $\begin{array}{l}\text { DOE, Japan, } \\
\text { France }\end{array}$ \\
\hline
\end{tabular}


Table 5 (continued)

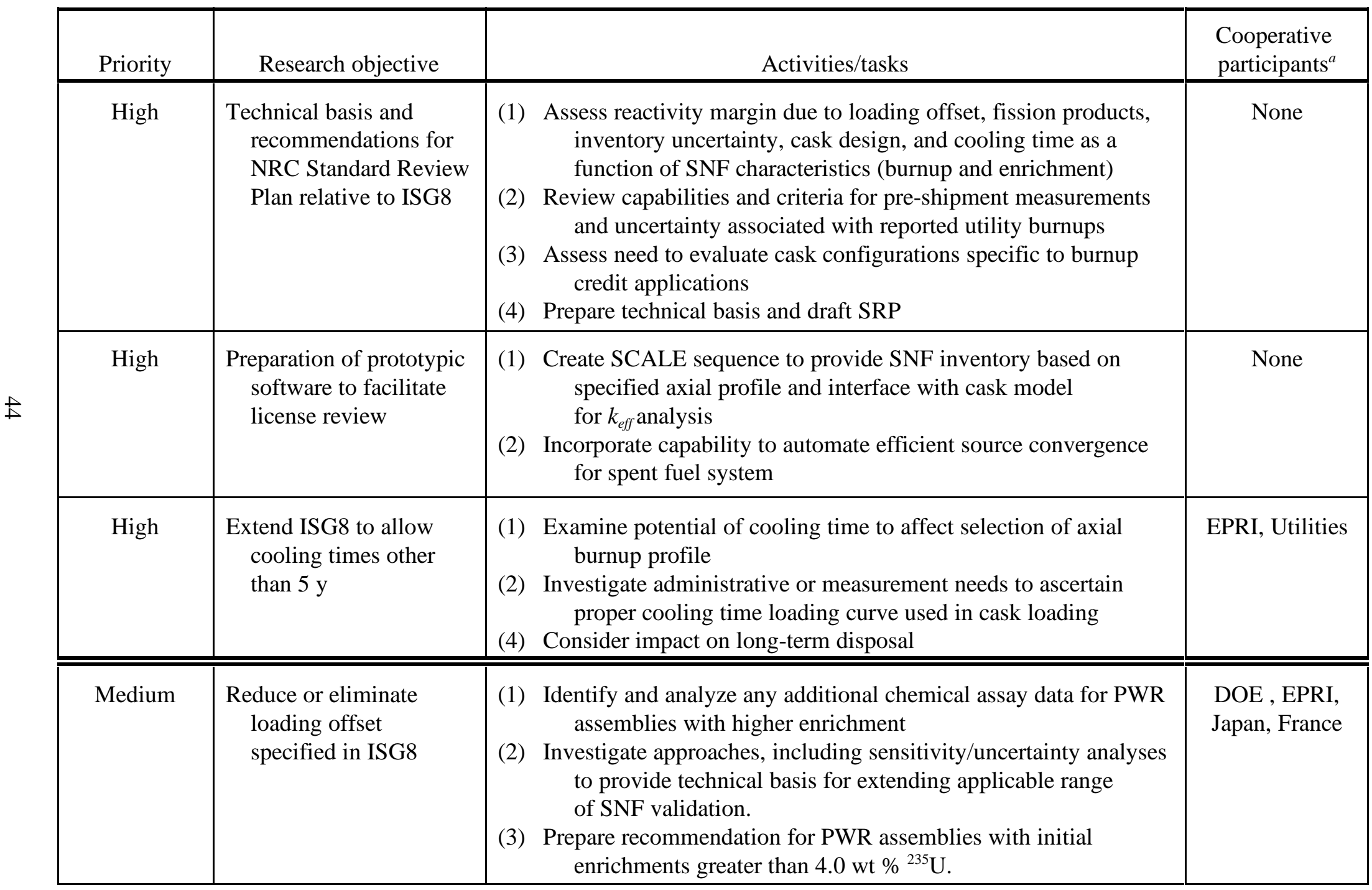


Table 5 (continued)

\begin{tabular}{|c|c|c|c|}
\hline Priority & Research objective & Activities/tasks & $\begin{array}{l}\text { Cooperative } \\
\text { participants }^{a}\end{array}$ \\
\hline Medium & $\begin{array}{l}\text { Increase limit on PWR } \\
\text { burnup credit } \\
\text { allowance beyond } \\
40 \mathrm{GWd} / \mathrm{MTU}\end{array}$ & $\begin{array}{l}\text { (1) Identify and analyze any additional chemical assay data for } \\
\text { assemblies with burnup values greater than } 40 \mathrm{GWd} / \mathrm{MTU} \\
\text { (2) Investigate approaches, including sensitivity/uncertainty analyses } \\
\text { to provide technical basis for extending applicable range } \\
\text { of SNF validation } \\
\text { (3) Prepare recommendation for extending the allowance for burnup } \\
\text { beyond } 40 \mathrm{GWd} / \mathrm{MTU} \text { for PWR assemblies }\end{array}$ & $\begin{array}{c}\text { DOE, EPRI, France, } \\
\text { Japan }\end{array}$ \\
\hline Medium & $\begin{array}{l}\text { Extend ISG8 to provide } \\
\text { recommendations for } \\
\text { allowance of fission } \\
\text { product nuclides }\end{array}$ & $\begin{array}{l}\text { (1) Identify and analyze any additional chemical assay data with } \\
\text { fission product measurements } \\
\text { (2) Review uncertainty associated with fission product cross sections } \\
\text { (3) Evaluate use of reactivity worth, subcritical experiments, and } \\
\text { reactor critical configurations for validation of fission } \\
\text { products in burnup credit applications } \\
\text { (4) Assess uncertainty associated with fission product inventory } \\
\text { (5) Assess and update axial profile and depletion analysis parameter } \\
\text { recommendations } \\
\text { (6) Estimate margin of subcriticality from nuclides not credited } \\
\text { (7) Develop recommendations for allowance of fission product } \\
\text { nuclides }\end{array}$ & $\begin{array}{l}\text { DOE, EPRI, France, } \\
\text { Japan, OECD }\end{array}$ \\
\hline
\end{tabular}


Table 5 (continued)

\begin{tabular}{|c|c|c|c|}
\hline Priority & Research objective & Activities/tasks & $\begin{array}{l}\text { Cooperative } \\
\text { participants }^{a}\end{array}$ \\
\hline Medium & $\begin{array}{l}\text { Reduce conservatism in } \\
\text { the horizontal burnup } \\
\text { distribution }\end{array}$ & $\begin{array}{l}\text { (1) Identify and evaluate measured data related to horizontal burnup } \\
\text { variations } \\
\text { (2) Evaluate potential for reduced variation at ends } \\
\text { (3) Develop recommendation(s) }\end{array}$ & EPRI, NEI \\
\hline Low & $\begin{array}{l}\text { Improve efficiency of } \\
\text { operations with PWR } \\
\text { spent fuel }\end{array}$ & $\begin{array}{l}\text { (1) Evaluate new experiment data to improve estimate of margin } \\
\text { of subcriticality } \\
\text { (2) Evaluate potential/necessity of expanding axial burnup profile } \\
\text { database to include new assembly designs } \\
\text { (3) Evaluate potential for improving efficiency and effectiveness } \\
\text { of pre-shipment loading procedures } \\
\text { (4) Evaluate potential for pre-shipment measurement to allow use } \\
\text { of less limiting axial and horizontal burnup profiles } \\
\text { (5) Investigate benefits and practical implementation of subcritical } \\
\text { experiments for pre-shipment measurement }\end{array}$ & EPRI, NEI \\
\hline Low & $\begin{array}{l}\text { Assess benefits and } \\
\text { needs of burnup credit } \\
\text { for BWR assemblies }\end{array}$ & $\begin{array}{l}\text { (1) Survey industry needs relative to burnup credit in BWR casks } \\
\text { (2) Use reference cask designs to assess the amount of burnup credit } \\
\text { required to meet industry needs }\end{array}$ & EPRI, NEI \\
\hline
\end{tabular}


Table 5 (continued)

\begin{tabular}{|c|c|c|c|}
\hline Priority & Research objective & Activities/tasks & $\begin{array}{l}\text { Cooperative } \\
\text { participants }^{a}\end{array}$ \\
\hline Low & $\begin{array}{l}\text { Develop } \\
\text { recommendations for } \\
\text { allowance of burnup } \\
\text { credit for BWRs, } \\
\text { if needed }\end{array}$ & $\begin{array}{l}\text { (1) Reference report for BWR operations providing } \mathrm{T}_{\mathrm{f}} \text { and moderator } \\
\text { void fraction } \\
\text { (2) Study to understand effects of exposure history } \\
\text { (3) Develop profile database for BWR assemblies } \\
\text { (4) Confirm process for determining bounding axial profile and } \\
\text { determine process for determining horizontal profile } \\
\text { (5) Identify and analyze additional chemical assay data for BWR SNF } \\
\text { (6) Perform study of multidimensional modeling effects in depletion } \\
\text { analysis } \\
\text { (7) Perform sensitivity/uncertainty analysis to evaluate applicability } \\
\text { of critical experiment data for BWR SNF } \\
\text { (8) Assess adequacy of prototypic codes and models for use with } \\
\text { BWR assemblies } \\
\text { (9) Develop technical basis and recommendations for use of burnup } \\
\text { credit with BWR fuel }\end{array}$ & $\begin{array}{l}\text { EPRI, NEI, DOE, } \\
\text { Japan }\end{array}$ \\
\hline Low & $\begin{array}{l}\text { Assess benefits and } \\
\text { needs of burnup credit } \\
\text { with MOX assemblies } \\
\text { (PWR and BWR) }\end{array}$ & $\begin{array}{l}\text { (1) Survey industry needs relative to burnup credit in casks designed } \\
\text { for MOX fuel } \\
\text { (2) Use reference cask designs to assess the amount of burnup credit } \\
\text { required to meet industry needs }\end{array}$ & DOE, EPRI, NEI \\
\hline
\end{tabular}


Table 5 (continued)

\begin{tabular}{|c|c|c|c|}
\hline Priority & Research objective & Activities/tasks & $\begin{array}{l}\text { Cooperative } \\
\text { participants }^{a}\end{array}$ \\
\hline Low & $\begin{array}{l}\text { Develop } \\
\text { recommendations for } \\
\text { allowance of burnup } \\
\text { credit for MOX fuel, } \\
\text { if needed }\end{array}$ & $\begin{array}{l}\text { (1) Reference report for BWR and PWR operations with MOX fuel } \\
\text { (2) Study to understand effects of exposure history } \\
\text { (3) Develop profile database(s) for MOX assemblies } \\
\text { (4) Confirm process for determining bounding axial profile and } \\
\text { determine process for determining horizontal profile } \\
\text { (5) Identify and analyze additional chemical assay data for MOX SNF } \\
\text { (6) Perform study of multidimensional modeling effects in depletion } \\
\text { analysis } \\
\text { (7) Perform sensitivity/uncertainty analysis to evaluate applicability } \\
\text { of experimental data for MOX SNF } \\
\text { (8) Assess adequacy of prototypic codes and models for use with } \\
\text { MOX assemblies } \\
\text { (9) Develop technical basis and recommendations for use of burnup } \\
\text { credit with MOX fuel }\end{array}$ & DOE, OECD \\
\hline
\end{tabular}

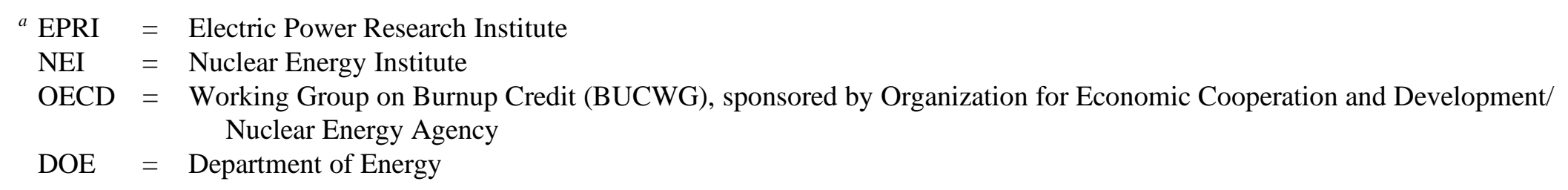




\section{REFERENCES}

1. NUREG-1536, Standard Review Plan for Dry Cask Storage Systems, USNRC, Washington, D.C., January 1997.

2. NUREG-1617, Standard Review Plan for Transportation Packages for Spent Nuclear Fuel - Draft Report for Comment, USNRC, Washington, D.C., March 1998.

3. T. L. Sanders, R. M. Westfall, and R. H. Jones, Feasibility and Incentives for the Consideration of Spent Fuel Operating Histories in the Criticality Analysis of Spent Fuel Shipping Casks, SAND87-0151, TTC-0713, UC71, Sandia National Laboratory (August 1987).

4. T. L. Sanders, editor, "Proceedings of a Workshop on the Use of Burnup Credit in Spent Fuel Transport Casks," Washington D.C., February 21-22, 1988, SAND89-0018, TTC-0884, UC-820, Sandia National Laboratory (October 1989).

5. T. L. Sanders and R. M. Westfall, "Feasibility and Incentives for Burnup Credit in Spent Fuel Transport Casks," Nucl. Sci. Eng. 104 (1990).

6. "Guidance on the Regulatory Requirements for Criticality Safety Analysis of Fuel Storage at Light-Water Reactor Power Plants," NRC memorandum from L. I. Kopp to T. Collins, August 19, 1998, U.S. Nuclear Regulatory Commission.

7. "Spent Fuel Project Office Interim Staff Guidance - 8, Rev. 1 - Limited Burnup Credit," USNRC, July 30, 1999.

8. Regulations for the Safe Transport of Radioactive Material, 1996 Edition. IAEA Safety Standards Series No. ST-1, International Atomic Energy Agency (1996).

9. Disposal Criticality Analysis Methodology Topical Report, YMP/TR-004Q Revision 0, U.S. Department of Energy Office of Civilian Radioactive Waste Management Yucca Mountain Site Characterization Project, November 1998.

10. "Spent Fuel Project Office Interim Staff Guidance - 8, Rev. 0 - Limited Burnup Credit," USNRC, May 13, 1999.

11. Office of Civilian Radioactive Waste Management, Topical Report on Actinide-Only Burnup Credit for PWR Spent Nuclear Fuel Packages, DOE/RW-0472, Rev. 2, U.S. Department of Energy, Office of Civilian Radioactive Waste Management, September 1998.

12. J. C. Neuber, "Criticality Analysis of BWR Spent Fuel Storage Facilities Inside Nuclear Power Plants," Vol. IV, p. 1624 in Proceedings of the $6^{\text {th }}$ International Conference on Nuclear Criticality, September 1999.

13. B. H. Wakeman and S. A. Ahmed, Evaluation of Burnup Credit for Dry Storage Casks, EPRI NP-6494, Electric Power Research Institute (August 1989). 
14. M. Takano and H. Okuno, OECD/NEA Burnup Credit Criticality Benchmark - Result of Phase IIA, JAERI-Research-96-003 (NEA/NSC/DOC(61)01), Japan Atomic Energy Research Institute, 1996.

15. M. Takano, OECD/NEA Burnup Credit Criticality Benchmark - Result of Phase-1A, JAERI-M 94-003 (NEA/NSC/DOC(93)22, Japan Atomic Energy Research Institute, 1994.

16. M. D. DeHart et al., OECD/NEA Burnup Credit Calculational Criticality Benchmark Phase I-B Results, ORNL-6901 (NEA/NSC/DOC(96)-06), Lockheed Martin Energy Research Corp., Oak Ridge National Laboratory, June 1996.

17. A. Houri, OECD/NEA Burnup Credit Criticality Benchmark - Analysis of Phase II-B Results: Conceptual PWR Spent Fuel Transportation Cask, IPS/98-05 (NEA/NSC/DOC(98)1), Instituted de Protection et de Surety Nuclear, May 1998.

18. H. Okuno et al., "International Studies on Burnup Credit Criticality Safety by an OECD/NEA Working Group: Calculation of Benchmarks for BWR Spent Fuels," Vol. II, p. 566 in Proceedings of the $6^{\text {th }}$ International Conference on Nuclear Criticality Safety (September 1999).

19. Implementation of Burnup Credit in Spent Fuel Management Systems, Proceedings of an Advisory Group Meeting held in Vienna, Austria October 20-24, 1997, IAEA-TECDOC-1013 (April 1998).

20. H. P. Dyck et al., "Overview of the Burnup Credit Activities at the IAEA," Vol. II, p. 576 in Proceedings of the $6^{\text {th }}$ International Conference on Nuclear Criticality (September 1999).

21. M. D. DeHart, Sensitivity and Parametric Evaluations of Significant Aspects of Burnup Credit for PWR Spent Fuel Packages, ORNL/TM-12973, Lockheed Martin Energy Research Corp., Oak Ridge National Laboratory, May 1996.

22. B. L. Broadhead et al., Investigation of Nuclide Importance to Functional Requirements Related to Transport and Long-Term Storage of LWR Spent Fuel, ORNL/TM-12742, Lockheed Martin Energy Systems, Inc., Oak Ridge National Laboratory, June 1995.

23. B. L. Broadhead, K-infinite Trends with Burnup, Enrichment, and Cooling Time, for BWR Fuel Assemblies, ORNL/M-6155, Lockheed Martin Energy Research Corp., Oak Ridge National Laboratory, August 1998.

24. O. W. Hermann et al., Validation of the SCALE System for PWR Spent Fuel Isotopic Composition Analyses, ORNL/TM-12667, Martin Marietta Energy Systems, Inc., Oak Ridge National Laboratory, 1995.

25. M. D. DeHart and O. W. Hermann, An Extension of the Validation of SCALE (SAS2H) Isotopic Predictions for PWR Spent Fuel, ORNL/TM-13317, Lockheed Martin Energy Research Corp., Oak Ridge National Laboratory, September 1996.

26. O. W. Hermann and M. D. DeHart, Validation of SCALE (SAS2H) Isotopic Predictions for BWR Spent Fuel, ORNL/TM-13315, Lockheed Martin Energy Research Corp., Oak Ridge National Laboratory, September 1998. 
27. C. V. Parks, "Parametric Neutronic Analyses Related to Burnup Credit Cask Design," pp. 21-43 in Proceedings of a Workshop on the Use of Burnup Credit in Spent Fuel Transport Casks, Washington D.C., February 21-22, 1988, SAND89-0018, TTC-0884, UC-820, Sandia National Laboratory (October 1989).

28. M. D. DeHart, Parametric Analysis Of PWR Spent Fuel Depletion Parameters For Long-Term Disposal Criticality Safety, ORNL/TM-1999/99, Lockheed Martin Energy Research Corp., Oak Ridge National Laboratory, October 1999.

29. C. H. Kang and D. B. Lancaster, "Actinide-Only Burnup Credit for Pressurized Water Reactor Spent Nuclear Fuel - III: Bounding Treatment of Spatial Burnup Distributions," Nucl. Technol. 125, 292 (1999).

30. J. C. Wagner et al., Investigation of Burnup Credit Modeling Issues Associated with BWR Fuel, ORNL/TM-1999/193, Lockheed Martin Energy Research Corp., Oak Ridge National Laboratory, October 1999.

31. C. H. Kang and D. B. Lancaster, Depletion and Package Modeling Assumptions for Actinide-Only Burnup Credit, DOE/RW-0495, U.S. Department of Energy (1997).

32. P. R. Thorne, G. J. O'Conner, R. L. Bowden, "The Current Status of the Methods Adopted by BNFL in Claiming Credit for Burnup in Criticality Safety Assessments," Sixth Int. Conf. on Nuclear Criticality Safety, Versailles, France, September 20-24, 1999.

33. J. C. Wagner and M. D. DeHart, Review of Axial Burnup Distribution Considerations for Burnup Credit Calculations, ORNL/TM-1999/246, Lockheed Martin Energy Research Corp., Oak Ridge National Laboratory, in 2000.

34. M. C. Brady, C. V. Parks, and C. R. Marotta, "End Effects in the Criticality Analysis of Burnup Credit Casks," Trans. Am. Nucl Soc. 62, 317 (1990).

35. T. A. Parish and C. H. Chen, "Bounding Axial Profile Analysis for the Topical Report Database," Nuclear Engineering Dept., Texas A\&M University, March 1997.

36. B. L. Broadhead, "Feasibility Assessment of Burnup Credit in the Criticality Analysis of Shipping Casks with Boiling Water Reactor Spent Fuel," Nucl. Technol. 110, 1-21, April 1995.

37. R. J. Cacciapouti and S. Van Volkinburg, Axial Burnup Profile Database for Pressurized Water Reactors, YAEC-1937, Yankee Atomic Electric Company, May 1997.

38. Determination of the Accuracy of Utility Spent Fuel Burnup Records - Interim Report, EPRI TR-109929, May 1998.

39. L. E. Wiles, N. J. Lombardo, C. M. Heeb, U. P. Jenquin, T. E. Michener, C. L. Wheeler, J. M. Creer, and R. A. McCann, BWR Spent Fuel Storage Cask Performance Test, PNL-5777, Vol. II, Pacific Northwest Laboratory, June 1986.

40. R. J. Guenther et al., Characterization of Spent Fuel Approved Testing Material - ATM-105, PNL-5109105, Pacific Northwest Laboratory, 1991. 
41. Horizontal Burnup Gradient Datafile for PWR Assemblies, DOE/RW-0496, U.S. Department of Energy, Office of Civilian Radioactive Waste Management, May 1997.

42. J. O. Barner, Characterization of LWR Spent Fuel MCC-Approved Testing Material -ATM-101, PNL5109, Rev. 1, Pacific Northwest Laboratory, 1985.

43. R. J. Guenther et al., Characterization of Spent Fuel Approved Testing Material - ATM-103, PNL-5109103, Pacific Northwest Laboratory, 1988.

44. R. J. Guenther et al., Characterization of Spent Fuel Approved Testing Material - ATM-104, PNL-5109104, Pacific Northwest Laboratory, 1991.

45. R. J. Guenther et al., Characterization of Spent Fuel Approved Testing Material - ATM-106, PNL-5109106, Pacific Northwest Laboratory, 1988.

46. A. M. Bresesti et al., Post-Irradiation Analysis of Trino Vercelles Reactor Fuel Elements, EUR-4909e, Joint Nuclear Research Centre Ispra and Karlsruhe Establishments, 1972.

47. P. Barbero et al., Post-Irradiation Examination of the Fuel Discharged from the Trino Vercelles Reactor After the $2^{\text {nd }}$ Irradiation Cycle, EUR-5605e, Joint Nuclear Research Centre Ispra and Karlsruhe Establishments, 1977.

48. S. D. Atkin, Destructive Examination of 3-Cycle LWR Fuel Rods from Turkey Point Unit 3 for the CLIMAX-Spent Fuel Test, HEDL-TME 80-89, Hanford Engineering Development Laboratory, 1981.

49. P. Barbero et al.,Post-Irradiation Analysis of the Gundremmingen BWR Spent Fuel, EUR-6301en, Joint Research Center Ispra and Karlsruhe Establishments, 1979.

50. Y. Naito, M. Kurosawa, and T. Kaneko, Data Book of the Isotopic Composition of Spent Fuel in Light Water Reactors, JAERI-M 94-034, Japan Atomic Energy Research Institute, 1994.

51. S. E. Fisher and F. C. Defilippo, Neutronics Benchmark for the Quad Cities-1 (Cycle 2) Mixed-Oxide Assembly Irradiation, ORNL/TM-13567, Lockheed Martin Energy Research Corp., Oak Ridge National Laboratory, April 1998.

52. O. W. Hermann, San Onofre PWR Data for Code Validation of MOX Fuel Depletion Analyses, ORNL/TM1999/108, Lockheed Martin Energy Research, Oak Ridge National Laboratory, September 1999.

53. O. W. Hermann, M. D. DeHart, and B. D. Murphy, Evaluation of Measured LWR Spent Fuel Composition Data for Use in Code Validation, ORNL/M-6121, Lockheed Martin Energy Research Corp., Oak Ridge National Laboratory, February 1998.

54. J. J. Lichtenwalter et. al., Criticality Benchmark Guide for Light-Water-Reactor Fuel in Transportation and Storage Packages, NUREG/CR-6361(ORNL/13211), U.S. Nuclear Regulatory Commission, Oak Ridge National Laboratory, March 1997.

55. C. Lavarenne, E. Letang, O. Dekens, M. Doucet, J. P. Grouiller, N. Thiollay, and E. Guillou, "Taking Burnup Credit into Account in Criticality Studies: The Situation as it is Now and the Prospect for the 
Future," Vol. II, p. 629 in Proceedings of the $6^{\text {th }}$ International Conference on Nuclear Criticality Safety, September 1999.

56. N. Thiollay et al., "Burnup Credit for Fission Product Nuclides in PWR ( $\left.\mathrm{UO}_{2}\right)$ Spent Fuels," Vol. II, p. 612 in Proceedings of the $6^{\text {th }}$ International Conference on Nuclear Criticality Safety, September 1999.

57. G. A. Harms, F. J. Davis, and J. T. Ford, "The Spent Fuel Safety Experiment," pp. 5·3 - 5·9, in Proc. Of The Fifth International Conference on Nuclear Criticality, September 17-21, 1995, Albuquerque, New Mexico (1995).

58. J. Basselier, T. Maldague, A. Renard, H. Abderrahim, S. Bodart, P. D’hondt, K. Van der Meer, V. Rypar, C. Svoboda, I. Vasa, "Critical Experiment with Spent Fuel for Burn-Up Credit Validation (REBUS International Programme)," Vol. II, p. 603 in Proceedings of the $6^{\text {th }}$ International Conference on Nuclear Criticality Safety, September 1999.

59. S. R. Bierman, "Feasibility of Performing Criticality Experiments with Spent LWR Fuel," pp. 179-188 in Proceedings of a Workshop on the Use of Burnup Credit in Spent Fuel Transport Casks, Washington D.C., February 21-22, 1988, SAND89-0018, TTC-0884, UC-820, Sandia National Laboratory, October 1989.

60. T. E. Valentine, Review of Subcritical Source-Driven Noise Analysis Measurements, ORNL/TM-1999/288, Lockheed Martin Energy Research Corp., Oak Ridge National Laboratory, November 1999.

61. M. D. DeHart, SCALE-4 Analysis of Pressurized Water Reactor Critical Configurations: Volume 1 Summary, ORNL/TM-12294/V1, Martin Marietta Energy Systems, Inc., Oak Ridge National Laboratory, March 1995.

62. Office of Civilian Radioactive Waste Management M\&O Contractor, Summary Report of Commercial Reactor Critical Analyses Performed for the Disposal Criticality Analysis Methodology, B0000000001717-5705-00075 REV 00, U.S. Department of Energy, Yucca Mountain Site Characterization Project Office, September 1997.

63. C. V. Parks, "An Approach for Verifying Analysis Techniques Applicable to the Burnup Credit Technical Issue," pp. 189-196 in Proceedings of a Workshop on the Use of Burnup Credit in Spent Fuel Transport Casks, Washington D.C., February 21-22, 1988, SAND89-0018, TTC-0884, UC-820, Sandia National Laboratory (October 1989).

64. B. L. Broadhead, C. M. Hopper, R. L. Childs, and C. V. Parks, Sensitivity and Uncertainty Analyses Applied to Criticality Validation, Volume 1: Methods Development, NUREG.CR-6655, Vol. 1 (ORNL/TM13692/V1), U.S. Nuclear Regulatory Commission, Oak Ridge National Laboratory, November 1999.

65. B. L. Broadhead, C. M. Hopper, and C. V. Parks, Sensitivity and Uncertainty Analyses Applied to Criticality Validation, Volume 2: Illustrative Applications and Initial Guidance, NUREG.CR-6655, Vol. 2 (ORNL/TM-13692/V2), U.S. Nuclear Regulatory Commission, Oak Ridge National Laboratory, November 1999.

66. O. W. Hermann and C. V. Parks, "SAS2H: A Coupled One-Dimensional Depletion and Shielding Analysis Module," Vol. I, Sect. S2 of SCALE: A Modular Code System for Performing Standardized Computer Analyses for Licensing Evaluation, NUREG/CR-0200, Rev. 5 (ORNL/NUREG/CSD-2R5), March 1997. 
Available from Radiation Safety Information Computational Center at Oak Ridge National Laboratory as CCC-545.

67. B. D. Murphy, Prediction of the Isotopic Composition of $\mathrm{UO}_{2}$ Fuel from a BWR: Analysis of the DU1 Sample from the Dodewaard Reactor, ORNL/TM-13687, Lockheed Martin Energy Research Corporation, Oak Ridge National Laboratory, October 1998.

68. H. R. Dyer and C. V. Parks, Recommendations for Preparing the Criticality Safety Evaluation of Transportation Packages, NUREG/CR-5661 (ORNL/TM-11936), Lockheed Martin Energy Research Corporation, Oak Ridge National Laboratory, March 1997.

69. I. C. Gauld, Limited Burnup Credit in Criticality Safety Analyses: A Comparison of ISG-8 and Current International Practice, ORNL/TM-1999/999, U.S. Nuclear Regulatory Commission, Oak Ridge National Laboratory, in 2000.

70. F. Barbry, A. Laviron, P. Fouillaud, P. Cousinou, G. Poullot, "Experimental Criticality Study Programmes and Test Potential of the IPSN/VALDUC Criticality Laboratory," Vol. III, p. 1502 in Proceedings of the $6^{\text {th }}$ International Conference on Nuclear Criticality Safety, September 1999.

71. M. Maillot, E. Guillou, D. Biron, and S. Janski, "Search for an Envelope Axial Burnup Profile for Use in PWR Criticality Studies with Burnup Credit," Vol. IV, p. 1684 in Proceedings of the $6^{\text {th }}$ International Conference on Nuclear Criticality Safety, September 1999.

72. N. Harris et al., "The Development of a Burn-up Criticality Safety Case for the Thorp Reprocessing Plant," Vol. II, p. 622 in Proceedings of the $6^{\text {th }}$ International Conference on Nuclear Criticality, September 1999.

73. R. L. Bowden, P. R. Thorne, and P. I. D. Strafford, "The Methodology Adopted by British Nuclear Fuels PLC in Claiming Credit for Reactor Fuel Burnup in Criticality Safety Assessments," Vol. I, p. I-B-3 in Proceedings of the $5^{\text {th }}$ International Conference on Nuclear Criticality Safety, September 1995.

74. Y. Naito, M. Takano, M. Kurosawa, and T. Suzaki, "Study of the Criticality Safety Evaluation Method for Burnup Credit in JAERI," Nucl. Technol. 110 (1995). 
APPENDIX A

STATUS OF BURNUP CREDIT PROGRAMS BY COUNTRY 



\section{APPENDIX A \\ STATUS OF BURNUP CREDIT PROGRAMS BY COUNTRY}

This appendix seeks to provide an informal, qualitative review of industry and government efforts to address burnup credit issues in various countries. The review is by no means exhaustive; more specific and quantitative information can be found in Refs. 19-20 and the references cited herein.

\section{France}

The French burnup credit program is currently the most comprehensive of all the countries seeking to implement burnup credit in nuclear operations. For nearly a decade the French have used a simple, bounding approach to enable the use of burnup credit in transport, storage, and reprocessing of PWR spent fuel. For transport and storage the French allow burnup credit commensurate with the lowest average burnup in any contiguous $50-\mathrm{cm}$ portion of the assembly. The credit is limited to consideration for plutonium and uranium isotopes only. In 1991, the French industry and the Institute for Protection and Nuclear Safety (IPSN) initiated a joint experimental program to support the extension of burnup credit. The work performed at CEA-Cadarache was recently described in papers presented at the International Conference on Nuclear Criticality (ICNC) $55-56$

The CEA-Cadarache program involves destructive assays of spent fuel and reactivity-worth measurements. The PWR assay information includes fuel with initial enrichments up to 4.5 -wt $\%{ }^{235} \mathrm{U}$ and burnup values to $61.2 \mathrm{GWd} / \mathrm{MTU}$. A table of the percentage difference between calculated and measured values indicates that the French observe an overprediction of the fission product inventory and excellent agreement with important actinides. Interestingly, there appears to be an improvement in the agreement as the burnup increases. Of particular value to the United States would be the fact that assays are available at high burnup and high initial enrichment and that assay data are available for ${ }^{103} \mathrm{Rh}$, one of the leading fission product absorbers. Oscillating reactivity-worth measurements in the MINERVE reactor have been performed using 13 samples doped with a fission product of importance to burnup credit. The calculated-to-measured results were provided, along with a demonstration that the French have done a thorough job of trying to understand the reasons for disagreements between the measured and calculated information for each fission product worth measurement. Integral reactivity-worth measurements using PWR spent fuel samples were also performed and the calculated-to-measured values reported. Analyses using the CRISTAL code package indicate an underestimate of the actual fuel reactivity loss due to irradiation (conservative), which is accounted for in part by the presence of fission products not used in the calculations. A similar experimental program has been performed at Cadarache for MOX spent fuel, and a program for BWR spent fuel has been initiated. Beginning in 2001, the French plan to return to the PWR work with the goal to extend the burnups to $>70 \mathrm{GWd} / \mathrm{MTU}$. All of this experimental information is considered proprietary by Cogema and Framatome, who funded most of the work. However, efforts should be made to obtain the data for use in regulatory research programs and/or licensing within the United States. [Note the DOE did participate in Phase III of the PWR program, where the reactivity worth of spent fuel samples was obtained. ORNL has this proprietary information and may be able to analyze it using tools of interest to the NRC research program.]

At the IPSN facilities in Valduc, a multistage critical experiment program related to burnup credit is currently under way. The program utilizes a subcritical approach to find the critical height of water ${ }^{70}$ The first experiments of interest to the United States would be ones performed from 1986 to 1991 using rods designated as "HTC" rods: MOX rods with a plutonium-to-uranium mixture commensurate with 4.5-wt \%-enriched $\mathrm{UO}_{2}$ rods burned to 37.5 GWd/MTU. These experiments would be very applicable to the current U.S. interests in actinide-only burnup 
credit, because the range of experimental parameters covered regular lattice arrays of varying pitch under storage and transport conditions (e.g., various reflector and interstitial poisons). Before having to stop work in 1995 to renovate the facility, a critical experiment with ${ }^{149} \mathrm{Sm}$ in canned solution surrounded by a $\mathrm{UO}_{2}$ pin lattice had also been performed. Similar experiments are now under way for five additional fission products $\left({ }^{103} \mathrm{Rh},{ }^{133} \mathrm{Cs},{ }^{143} \mathrm{Nd}\right.$, ${ }^{152} \mathrm{Sm}$, and ${ }^{155} \mathrm{Gd}$ ). Beyond these experiments, a series of experiments are planned using a combination of the HTC and $\mathrm{UO}_{2}$ rods in a fission product solution. The last series of experiments, where the HTC and $\mathrm{UO}_{2}$ rods are placed in the fission product solution, may be the best ones for obtaining the spectrum anticipated in a spent fuel cask. The Valduc experiments were funded by Cogema and IPSN at a cost of about $\$ 30$ million (although it was not clear if this covered all the phases of the experiments or just the latter ones with fission products). During a visit to Valduc, F. Barbry, head of the experimental program indicated that Cogema is now willing to negotiate with the U.S. NRC to make these experiments available for use.

An area where the French have considerable practical experience is in the measurement techniques and processes used to measure burnup of spent fuel assemblies. The French have measured burnup profile data for about 7000 assemblies sent to the La Hague plant for reprocessing.

With these experimental programs proceeding and measurement experience in place at reactor and reprocessing facilities, the French have now turned their attention to revising their approach for licensing burnup credit 55 In 1997 a working group consisting of representatives from government and the major nuclear industry concerns was formed to address the issues. The working group will focus on PWR fuel with the intent to extend the use of burnup credit while maintaining an adequate margin of safety. Four subgroups have been formed. The first subgroup will address depletion analyses and determine appropriate correction factors to account for discrepancies between calculations and measurements. The second subgroup will seek to classify "families" of burnup profiles based on measured profile data from La Hague and operating reactors and determine a bounding (leading to most reactive condition) for each "family." Initial results from this subgroup are presented in Ref. 71. The third subgroup has considered the determination of the operating history conditions that provide the most reactive nuclide inventory. As found in earlier work at ORNL, the operating conditions are those that provide the hardest spectrum and shortest irradiation time; thus, initial recommendations of this subgroup call for a continuous irradiation history using the highest average soluble boron concentration, outlet core temperature, and highest nominal specific power should be used in the depletion analyses. The fourth subgroup will seek to establish the model needed to assess burnup credit for storage and transport with particular attention to the axial modeling requirements. This work group is looking at models based on normal and accident conditions (e.g., models of loadings where the assemblies are not fully inserted below the poison basket of a cask). The coordination of the French approach with industry and the research branch of the French safety authorities should ensure that a consensus is reached for future applications.

Note that the technical work performed within the United States in recent years has already made significant strides towards addressing many of the subgroup areas discussed above.

\section{United Kingdom}

Like France, the United Kingdom industry, led by British Nuclear Fuels, Ltd. (BNFL), is seeking the potential benefit of burnup credit for application in transport, storage, and reprocessing 2 , 72,73 From storage to transportation and ultimately reprocessing, business operations in BNFL see the economic advantage of burnup credit as well as a substantial environmental benefit in reducing the waste stream from reprocessing plants (less gadolinium needed). BNFL is aided substantially by cooperative agreements with the French, which has provided 
them access to much of the reactivity-worth and assay data obtained in the experimental program at Cadarache. Even so, BNFL staff acknowledge the sparse assay data available for $\mathrm{UO}_{2}$ applications.

A licensing application for the Thorp Reprocessing Plant was submitted to the safety authorities in the United Kingdom nearly two years ago and it still awaits review. The BNFL process used in the safety case demonstrates that, like France, the reprocessing industry provides a venue for considerable experience applicable to practical approaches for measurements that ascertain the burnup of spent fuel prior to operations. BNFL utilizes a concept of residual enrichment to provide a single operating parameter for burnup credit. Residual enrichment is defined as the combination of initial enrichment and burnup. Further information on this parameter needs to be obtained to fully understand how it is defined and used.

Relative to transport, BNFL feels that the existing French approach of using the burnup associated with the least burned $50 \mathrm{~cm}$ portion of the fuel assembly will provide an acceptable approach for the burnup credit required in the near term. Approval for use of this credit has not been sought to date although BNFL has performed analytic studies similar to those performed within the United States ${ }^{72}$ Staff from the United Kingdom Department of the Environment, Transport, and the Regions (DETR) are looking for many of the same considerations noted in the recent NRC Interim Staff Guidance 8 released in August 1999. Two trial applications have been submitted by industry - each using substantially different approaches, but seemingly satisfying the basic tenets to address the important issues: isotopic and reactivity prediction and confirmation of fuel history.

\section{Germany}

In Germany, regulatory guidance on burnup credit in wet pool storage has been released and the safety basis of a German cask for limited burnup credit using the French approach has been approved. The Germans have been active participants in the OECD/NEA Working Group on Burnup Credit and have made considerable contributions relative to the impact of axial profiles. A description for an approach taken in applying full (actinide plus fission product) burnup credit for BWR fuel in wet storage pools has been presented 12 The approach has aspects that should also be considered in other burnup credit applications with BWR fuel. Specifically, the method described for treating the presence of integral burnable absorbers should be valuable for BWR burnup credit.

\section{Japan}

Both industry and government organizations in Japan have been investigating burnup credit issues for nearly a decade 74 In many ways, their efforts are similar to the work in the United States to date: there have been little new experimental data and the efforts have not had the coordinated approach as seen in France (industry/government partnering) or the United Kingdom (size and interests of BNFL). But Japan has an active interest in burnup credit, as evidenced by recent reports from Japan provided to the OECD/NEA Working Party on Criticality Safety. Destructive assays of PWR spent fuel with initial enrichments up to 4.5 -wt $\%{ }^{235} \mathrm{U}$ and $40-45$ GWd/MTU are in progress. The Japan Atomic Energy Research Institute (JAERI) is developing a database of spent fuel measured isotopic data. Also, a program to verify fission product cross-section data is being planned for the tank critical assembly (TCA). It is suspected that the verification will use reactivity worth measurements similar to those utilized in the French program at Cadarache. The end goal for JAERI is a burnup credit guide, which is in the planning stages. Similarly, the Japan Institute for Nuclear Safety is developing burnup credit criteria that will be used by operating fuel cycle facilities. Representatives from JAERI indicate continued interest in utilizing advanced subcritical measurement techniques to expand their capabilities for validation in conjunction with burnup credit issues. 
At ICNC'99 there were several papers from Japan on the topic of burnup credit. Several were on measurement techniques for burnup. One area where the Japanese have considerable interest and where collaboration could be helpful to U.S. efforts is relative to burnup credit for BWR spent fuel. Evidence of this is the fact that they had two papers relating to BWR burnup credit for transport and storage at the recent ICNC' 99.

\section{Belgium}

Even though the French have conducted a rather extensive experimental program within the confines of French proprietary interests, Belgonucleaire is seeking a commercial market for their development of experimental programs related to nuclear technology. Of interest to the area of burnup credit is the ARIANE program, which was begun in 1995 to assist in characterizing spent fuel isotopic data from MOX assemblies. As a baseline for the program, limited PWR and BWR $\mathrm{UO}_{2}$ fuel rods were assayed. This program is scheduled to be completed in March 2000, and the assay data will be available for public release after two years. The assay data should be of some benefit to studies related to the NRC research program since it contains $\mathrm{MOX}$ fuel and $\mathrm{UO}_{2}$ with burnups over $50 \mathrm{GWd} / \mathrm{MTU}$.

Belgonucleaire is currently seeking joint funding participation to support the REBUS program - an experiment to measure the reactivity worth of various spent fuel assembly segments within a research reactor environment (the LR-0 reactor in Czech Republic or the VENUS reactor in Belgium). The program currently plans to use 1-meter segments of PWR commercial fuel (4-wt \% initial enrichment and $60 \mathrm{GWd} / \mathrm{MTU}$ ) and $\mathrm{MOX}$ and $\mathrm{UO}_{2}$ fuel from the BR3 research reactor (20 to $30 \mathrm{GWd} / \mathrm{MTU}$ ). Thus, although the reactivity worth should be larger than seen in the French reactivity worth experiments with small samples, the range of characterizing parameters (burnup, initial enrichment, etc.) program is more limited. Also, the extensive research program to understand and separate the physics effects (e.g., the doped fission product samples of the French work) is not present. However, the REBUS program will provide destructive assays of the fuel to obtain isotopic compositions and axial gamma scans of the measured assemblies will be used for establishing the burnup profile. 
NUREG/CR-6665

ORNL/TM-1999/303

\section{INTERNAL DISTRIBUTION}

1. S. M. Bowman

2. B. L. Broadhead

3-12. W. C. Carter

13. M. D. DeHart

14. M. B. Emmett

15. I. C. Gauld

16. O. W. Hermann

17. C. M. Hopper

18. M. A. Kuliasha

19. S. B. Ludwig

20. B. D. Murphy

21-37. C. V. Parks

38. L. M. Petrie
39. R. T. Primm III

40. C. E. Pugh

41. J.-P. Renier

42. R. W. Roussin

43. J. C. Ryman

44. C. H. Shappert

45. T. E. Valentine

46. J. C. Wagner

47. R. M. Westfall

48. R. Q. Wright

49. Laboratory Records-RC

50. Central Research Library

\section{EXTERNAL DISTRIBUTION}

51. M. L. Anderson, Framatome Cogema Fuels, 1261 Town Center Drive, Las Vegas, Nevada 89134

52. M. G. Bailey, Office of Nuclear Material Safety \& Safeguards, U.S. Nuclear Regulatory Commission, MS O13 D13, Washington, DC 20555

53. F. Barbry, Institut de Protection et de Surete Nucleaire, Department de Prevention et D'Etude des Accidents, Centre de Valduc - SRSC - 21120 IS Sur Tille, France

54. L. Barrett, Office of Civilian Radioactive Waste Management, RW-232 20545, U.S. Department of Energy, Washington, DC 20545

55. C. J. Benson, Bettis Atomic Power Laboratory, P.O. Box 79, West Mifflin, PA 15122

56. G. H. Bidinger, NUMEC, 17016 Cashell Road, Rockville, MD 20853

57. J. Boshoven, Transnuclear West, Inc., 39300 Civic Center Drive, Suite 280, Fremont, CA 94538

58. M. C. Brady Raap, Battelle, Pacific Northwest National Laboratory, P.O. Box 999 / MS K8-34, Richland, WA 99352

59. J. B. Briggs, Idaho National Engineering \& Environmental Laboratory, P.O. Box 1625, MS-3890, Idaho Falls, ID 83415-3890

60. R. J. Cacciapouti, Yankee Atomic Electric Co., 1617 Worcester Rd., Framington, MA 01701 
61. D. E. Carlson, U.S. Nuclear Regulatory Commission, Spent Fuel Project Office, MS O13 D13, Washington, DC 20555

62. J. M. Conde López, Consejo de Seguridad Nuclear, Jefe de Area de Ingeniería Nuclear, Subdirección General de Technologia Nuclear, Justo Dorado, 11, 28040 Madrid, Spain

63. D. R. Conners, Bettis Atomic Power Laboratory, P.O. Box 79, West Mifflin, PA 15122

64. P. Cousinou, Institut de Protection et de Sûreté Nucleaire, Départment de Recherches en Sécurité, CECI B.P. 6 - 92265 Fontenzy-Aux-Roses, Cedex, France

65. W. Davis, Framatome Cogema Fuels, 1261 Town Center Drive, Las Vegas, Nevada 89134

66. T. W. Doering, Framatome Cogema Fuels, 1261 Town Center Drive, Las Vegas, Nevada 89134

67. P. Finck, Argonne National Lab., 9700 S. Cass Ave., Bldg. 360, Argonne, IL 60439

68. E. K. Fujita, Reactor Analysis Division, Argonne National Laboratory, 9700 South Case Avenue, Argonne, IL 60439-4801

69. H. Geiser, Wissenschaftlich-Technische Ingenieurberatung GmbH, P.O. Box 13 40, 52410 Julich, Federal Republic of Germany

70. R. N. B. Gmal, Gesellschaft für Anlagen-und Reaktorsicherheit (GRS) mbH, Leiter der Gruppe Kritikalität, Forschungsgelände, 85748 Garching b. München

71. P. Grimm, Paul Scherrer Institute, CH-5232 Villigen Psi, Switzerland

72. N. Gulliford, Winfrith Technology Centre, 306/A32, AEA Technology PLC, Winfrith, Dorchester, Dorset DT2 8DH, United Kingdom

73. S. Hanauer, U.S. Department of Energy, RW-22, Washington, DC 20545

74. G. Harms, Sandia National Laboratory, PO Box 5800, Mail Stop 1143, Albuquerque, New Mexico 87185-1143

75. L. A. Hassler, Framatome Cogema Fuels, 3315 Old Forest Road, P.O. Box 10935, Lynchburg, VA 24506-0935

76. D. Henderson, Framatome Cogema, 1261 Town Center Drive, Las Vegas, Nevada 89134

77. S. Janski, Electricité de France, EDF Industry, Basic Design Department, 12-14, Avenue Dutriévoz, 69628 Villeurbanne, Cedex, France

78. E. Johnson, E. R. Johnson Associates, Inc., 9302 Lee Hwy, Suite 200, Fairfax, VA 22031

79. R. A. Knief, XE Corporation (XEC), P.O. Box 90818, Albuquerque, NM 87199

80. H. Kühl, Wissenschaftlich-Technische Ingenieurberatung GMBH, Karl-HeinzBeckurts-Strasse 8, 52428 Jülich

81. W. H. Lake, Office of Civilian Radioactive Waste Management, U.S. Department of Energy, RW-46, Washington, DC 20585

82. D. B. Lancaster, Nuclear Consultants.com, 320 South Corl Street, State College, PA 16801 
83. C. Lavarenne, Institut de Protection et de Sûreté Nucléaire, Department of Prevention and Studies of Accidents, Criticality Studies Division, CEA - 60-68, avenue de Général Leclerc, B.P. 6 - 92265, Fontenay - Aux - Roses, Cedex, France

84. Y. L. Liu, Argonne National Laboratory, 9700 S. Cass Ave., Bldg.308, Argonne, IL 60439-4825

85. M. Mason, Transnuclear, Two Skyline Drive, Hawthorne, NY 10532-2120

86. A. J. Machiels, Electric Power Research Institute, Advanced Nuclear Technology, Energy Convervation Division, 3412 Hillview Ave., Palo Alto, CA 94304-1395

87. P. Malesys, Transnucleaire, 9-11, rue Christophe Colomb, 75008 Paris, France

88. L. Markova, Ustav jaderneho vyzkumu Rez, Theoretical Reactor Physics, Nuclear Research Institute, Czech Republic, 25068 REZ

89. B. Martinotti, Transnucleaire, 9-11, rue Christophe Colomb, 75008, Paris, France

90. C. W. Mays, Framatome Cogema Fuels, 3315 Old Forest Road, P.O. Box 10935, Lynchburg, VA 24506-0935

91. J. N. McKamy, U.S. Department of Energy, Office of Engineering Assistance and Site Interface, EH-34, 19901 Germantown Rd., Germantown, MD 20874

92. N. B. McLeod, JAI Corporation, 4103 Chain Bridge Road, Suite 200, Fairfax, VA 22030

93. D. Mennerdahl, E. Mennerdahl Systems, Starvägen 12, S-183 57 Täby, Sweden

94. K. A. Neimer, Duke Engineering \& Services, 400 S. Tyron St., WC26B, P.O. Box 1004, Charlotte, NC 28201-1004

95-99. C. W. Nilsen, Office of Nuclear Regulatory Research, U.S. Nuclear Regulatory Commission, MS T10 K08, Washington, DC 20555

100. P. Noel, Framatome Cogema, 1261 Town Center Drive, Las Vegas, Nevada

101. I. Nojiri, Japan Nuclear Cycle Development Institute, Environment and Safety Division, Tokai Works, Muramatsu Tokai-mura, Naka-gun Ibaraki-ken 319-1194, Japan

102. J. C. Neuber, SIEMENS AG, KWU NS-B, Berliner Str. 295-303, D-63067 OFFENBACH AM MAIN, Germany

103-104. Office of Scientific and Technical Information, U.S. Department of Energy, P.O. Box 62, Oak Ridge, TN 37831

105. Office of the Assistant Manager for Energy Research and Development, Department of Energy Oak Ridge Operations (DOE-ORO), P.O. Box 2008, Oak Ridge, TN 37831

106. H. Okuno, Japan Atomic Energy Research Institute, Department of Fuel Cycle, Safety Research, 2-4 Shirakata-Shirane, 319-1195 Tokai-mura, Naka-Gun, Ibaraki-ken, Japan

107. P. M. O’Leary, Framatome Technologies, 3315 Old Forest Road, P.O. Box 10935, Lynchburg, VA 24506-0935

108. N. L. Osgood, U.S. Nuclear Regulatory Commission, Office of Nuclear Materials Safety and Safeguards, MS O13 D13, Washington, DC 20555 
109. O. Ozer, Electric Power Research Institute, 3412 Hillview Ave., Palo Alto, CA 94304

110. T. Parish, Department of Nuclear Engineering, Texas A \& M University, College Station, TX 77843-3313

111. V. A. Perin, U.S. Nuclear Regulatory Commission, Office of Nuclear Material Safety and Safeguards, MS T10 K08, Washington, DC 20555

112. J. S. Philbin, Sandia National Laboratory, PO Box 5800, Mail Stop 1143, Albuquerque, New Mexico 87185-1143

113. M. Rahimi, U.S. Nuclear Regulatory Commission, Office of Nuclear Material Safety and Safeguards, MS T7 F3, Washington, DC 20555

114. C. Rombough, CTR Technical Services, Inc., 5619 Misty Crest Dr., Arlington, TX 76017-4147

115. D. Salmon, Framatome Cogema, 1261 Town Center Drive, Las Vegas, Nevada 89134

116. A. Santamarina, Commissariat A L'Energie Atomique, Nuclear Reactor Division, Reactor Studies Department, Reactor and Cycle Physics Service, CEA/CADARACHE/DRN/DER/SPRC Bat. 230, 13108 Saint-Paul-Lez-Durance, Cedex, France

117. E. Sartori, OECD/NEA Data Bank, Le Seine-Saint Germain, 12 Boulevard des Iles, F-92130 Issy-les-Moulineaux, France

118. H. H. Schweer, Bundesamt fuer Strahlenschutz, Willi Brandt Str. 5, D-38226 SALZGITTER, Germany

119. G. Sert, Institut de Protection et de Surete Nuclear, Department de Securite des Matieres Radioactives, B.P. 6 - 92265, Fontenay - AUX - Roses, Cedex France

120. D. N. Simister, Health and Safety Executive, Nuclear Installations Inspectorate, St Peter's House, Balliol Road, Bootle, Merseyside L20 3LZ

121. M. Smith, Virginia Power Co., P.O. Box 2666, Richmond, VA 23261

122. N. R. Smith, AEA Technology, A32 Winfrith, Dorchester, Dorset DT2 8DH, United Kingdom

123. J. T. Stewart, Department of Environment, Transport, and Re, RMTD, 4/18, GMH, 76 Marsham Street, London SW1P 4DR, United Kingdom

124. T. Suto, Power Reactor and Nuclear Fuel Development Corporation, Technical Service Division, Tokai Reprocessing Plant, Tokai Works, Tokai-Mura, Naka-gun, Ibaraki-ken, Japan

125. H. Taniuchi, Kobe Steel, Ltd., 2-3-1 Shinhama, Arai-Cho, Takasago, 676 Japan

126. D. A. Thomas, Framatome Cogema, 1261 Town Center Drive, Las Vegas, Nevada 89134

127. P. R. Thorne, British Nuclear Fuels plc (BNFL), Nuclear and Radiological Safety, R101 Rutherford House, Risley Warrington WA3 6AS, United Kingdom

128. J. R. Thornton, Duke Engineering \& Services, 230 S. Tyron St., P.O. Box 1004, Charlotte, NC 28201-1004 
129. S. E. Turner, HOLTEC International, 230 Normandy Circle East, Palm Harbor, FL 34683

130. M. E. Wangler, U.S. Department of Energy, EH-33.2, Washington, DC 205850002

131. W-J. Weber, Gesellschaft fuer Anlagenund Reaktorsicheheit, Forschungsgelaende, Postfach 1328, D-85739 GARCHING, Germany

132. A. Wells, 2846 Peachtree Walk, Duluth, GA 30136

133. W. Weyer, Wissenschaftlich-Technische Ingenieurberatung GMBH, Mozartstrasse 13, 5177 Titz-Rodingen, Federal Republic of Germany

134. B. H. White, U.S. Nuclear Regulatory Commission, Spent Fuel Project Office, MS O13 D13, Washington, DC 20555

135. C. J. Withee, U.S. Nuclear Regulatory Commission, Spent Fuel Project Office, MS O13 D13, Washington, DC 20555

136. R. Yang, Electric Power Research Institute, 3412 Hillview Ave., Palo Alto, CA 94304 


\begin{tabular}{|c|c|c|}
\hline $\begin{array}{l}\text { U.S. NUCLEAR REGULATORY COMMISSION } \\
\text { BIBLIOGRAPHIC DATA SHEET } \\
\text { ( See instructions on the reverse) }\end{array}$ & \multirow{2}{*}{\multicolumn{2}{|c|}{$\begin{array}{l}\text { 1. REPORT NUMBER } \\
\text { (Assigned by NRC, Add Vol., Supp., } \\
\text { Rev., and Addendum Numbers, } \\
\text { if any.) } \\
\text { NUREG/CR- } 6665 \\
\text { ORNL/TM-1999/303 }\end{array}$}} \\
\hline \multirow{4}{*}{$\begin{array}{l}\text { 2. TITLE AND SUBTITLE } \\
\text { Review and Prioritization of Technical Issues Related to Burnup Credit } \\
\text { for LWR Fuel }\end{array}$} & & \\
\hline & \multicolumn{2}{|c|}{ DATE REPORT PUBLISHED } \\
\hline & $\begin{array}{l}\text { MONTH } \\
\text { February }\end{array}$ & $\begin{array}{l}\text { YEAR } \\
2000\end{array}$ \\
\hline & \multicolumn{2}{|c|}{$\begin{array}{l}\text { 4. FIN OR GRANT NUMBER } \\
\text { W6479 }\end{array}$} \\
\hline 5. $A U T H O R(S)$ & \multicolumn{2}{|c|}{ 6. TYPE OF REPORT } \\
\hline \multirow[t]{2}{*}{ C. V. Parks, M. D. DeHart, and J. C. Wagner } & \multicolumn{2}{|c|}{ Technical } \\
\hline & \multicolumn{2}{|c|}{ 7. PERIOD COVERED (Inclusive Dates) } \\
\hline
\end{tabular}

8. PERFORMING ORGANIZATION - NAME AND ADDRESS (If NRC, provide Division, Office or Region, U.S. Nuclear Regulatory Commission, and mailing address; if contractor, provide name and mailing address.)

Oak Ridge National Laboratory

Managed by Lockheed Martin Energy Research Corporation

Oak Ridge, TN 37831-6370

9. SPONSORING ORGANIZATION - NAME AND ADDRESS (If NRC, type "Same as above"; if contractor, provide NRC Division, Office or Region, U.S. Regulatory Commission, and mailing address.)

Division of Systems Analysis and Regulatory Effectiveness

Office of Nuclear Regulatory Research

U.S. Nuclear Regulatory Commission

Washington, DC 20555-0001

10. SUPPLEMENTARY NOTES

C. W. Nilsen, NRC Project Manager

11. ABSTRACT (200 words or less)

This report has been prepared to review relevant background information and provide technical discussion that will help initiate a PIRT (Phenomena Identification and Ranking Tables) process for use of burnup credit in light-water reactor (LWR) spent fuel storage and transport cask applications. The PIRT process will be used by the NRC Office of Nuclear Regulatory Research to help prioritize and guide a coordinated program of research and as a means to obtain input/feedback from industry and other interested parties. The review and discussion in this report are based on knowledge and experience gained from work performed in the United States and other countries. Current regulatory practice and perceived industry needs are also reviewed as a background for prioritizing technical needs that will facilitate safe practice in the use of burnup credit. Relevant physics and analysis phenomenon are identified, and an assessment of their importance to burnup credit implementation is given. Finally, phenomena that need to be better understood for effective licensing, together with technical issues that require resolution, are presented and discussed in the form of a prioritization ranking and initial draft program plan.

12. KEY WORDS/DESCRIPTORS (List words or phrases that will assist researchers in locating the report.) criticality safety, burnup credit, transportation, dry storage

13. AVAILABILITY STATEMENT unlimited

14. SECURITY CLASSIFICATION (This Page) unclassified (This Report) unclassified 15. NUMBER OF PAGES

16. PRICE 
